UNIVERSIDADE DE SÃO PAULO

FACULDADE DE FILOSOFIA, LETRAS E CIÊNCIAS HUMANAS

DEPARTAMENTO DE LETRAS MODERNAS

PROGRAMA DE PÓS-GRADUAÇÃO EM ESTUDOS LINGUÍSTICOS, LITERÁRIOS E

TRADUTOLÓGICOS EM FRANCÊS

\title{
Atlas André Gide
}

São Paulo

2015 
BRUNA DE CARVALHO

\section{Atlas André Gide}

Dissertação apresentada ao Programa de Estudos Linguísticos, Literários e Tradutológicos em Francês do Departamento de Letras Modernas da Faculdade de Filosofia, Letras e Ciências Humanas da Universidade de São Paulo, para a obtenção do título de Mestre em Língua e Literatura Francesa.

Orientadora: Prof.a Dr.a Verónica Galíndez

São Paulo

2015 
Autorizo a divulgação total ou parcial deste trabalho, por qualquer meio convencional ou eletrônico, para fins de estudo e pesquisa, desde que citada a fonte. 
Nome: CARVALHO, Bruna de.

Título: Atlas André Gide

Dissertação apresentada ao Departamento de Letras Modernas da Universidade de São Paulo, para a obtenção do título de Mestre em Língua e Literatura Francesa.

Aprovado em:

Banca Examinadora:

Prof. Dr.

Instituição:

Julgamento:

Assinatura:

Prof. Dr.

Instituição:

Julgamento:

Assinatura:

Prof. Dr.

Instituição:

Julgamento:

Assinatura: 
RESUMO

Esta dissertação procura construir uma trajetória que atravesse pontos concernentes à enunciação em quatro livros de André Gide: La Symphonie pastorale, La Porte étroite, Les Faux-monnayeurs e Le Prométhée Mal Enchaîné. A enunciação será aqui pensada junto do artigo de Émile Benveniste intitulado "Da subjetividade na linguagem", em que o autor propõe que a subjetividade não seja vista como a substância psíquica sujeito, mas como um posicionamento tomado diante da língua. Não existiria, em outras palavras, sujeito anterior às coordenadas linguísticas que indicam o seu lugar de habitação - donde a tentativa de construção, em minha dissertação, de um espaço enunciativo em Gide. Levando em conta as publicações mencionadas, dividi as questões enunciativas em duas principais regiões: a primeira será lida do ponto de vista do pronome eu (La Symphonie pastorale e La Porte étroite) e a segunda, escrita sobretudo com o emprego da dita terceira pessoa (Les Faux-monnayeurs e Le Prométhée Mal Enchaîné), será pensada como, ela também, uma possibilidade enunciativa - isto é, como uma possibilidade de presença - a partir da emergência do conector mas. O foco na enunciação designa aqui um esforço em deslocar o olhar de determinados jargões que habitam os estudos literários (como o autor ou o narrador), de modo a fundar um campo em que a enunciação possa ser pensada em suas próprias condições de emergência. Ademais, pensar essas condições é também e sobretudo não ignorar o ponto de vista crítico, mas assumi-lo como parte integrante do espaço enunciativo gideano. Assim, junto da reflexão em torno da enunciação em Gide, elabora-se uma tentativa integrada de reflexão de minhas próprias condições para enunciar qualquer coisa que seja dentro desta dissertação.

PALAVRAS-CHAVE: André Gide; Enunciação; Espaço; Jean Starobinski; Crítica Literária. 


\section{ABSTRACT}

This dissertation aims at building a path that would cross some points concerning the enunciation in four of André Gide's books: La Symphonie pastorale, La Porte étroite, Les Fauxmonnayeurs e Le Prométhée Mal Enchaîné. The enunciation will be thought with Émile Benveniste's article "Subjectivity in language", in which the author proposes that subjectivity would rather be seen as position taken towards language than as a psychical subject. In other words, there is not a possible subject preceding the language coordinates that indicate its dwelling place - from this point, I attempt to build, in this dissertation, an enunciative space in Gide. Taking into consideration the referred publications, I divided the enunciative issues in two main regions: the first will be read under the perspective of the I (La Symphonie pastorale and La Porte étroite) and the second, written mostly with the use of the third person (Les Fauxmonnayeurs and Le Prométhée Mal Enchaîné), will be thought such as an enunciative possibility - which means a possibility of presence - from the emergence of the connector but. The focus on enunciation designates in this text an effort to dislocate the point of view of some jargons occupying today the literary studies (such as author or narrator) in order to establish a field in which the enunciation can be thought in its own emergence conditions. Moreover, thinking this conditions is also and above all not to overlook the critics point of view, but to assume it as an integral part of Gide's enunciative space. So with the reflection on Gide, I elaborate an integrated attempt of thinking about my own conditions of enunciating anything within this dissertation.

KEY-WORDS: André Gide; Enunciation; Space; Jean Starobinski; Literary Criticism. 
RESUMÉ

Ce travail a pour but de construire un trajet qui puisse traverser quelques points concernant l'énonciation dans quatre livres d'André Gide : La Symphonie pastorale, La Porte étroite, Les Faux-monnayeurs et Le Prométhée Mal Enchaîné. On réfléchira sur l'énonciation en présence de l'article d'Émile Benveniste « De la subjectivité dans le langage », dont l'auteur propose que la subjectivité ne soit pas la substance psychique sujet, mais une position à l'intérieur du langage. En d'autres mots, il n'existerait pas un sujet avant les coordonnées linguistiques qui indiquent sa place d'habitation - d'où l'essai de construire, dans mon texte, un espace énonciatif chez Gide. Compte tenu des publications mentionnées, j'ai réparti les questions énonciatives dans deux régions principales : la première sera lue du point de vue du pronom je (La Symphonie pastorale e La Porte étroite) et la deuxième, écrite surtout sous l'emploi de la dite troisième personne (Les Faux-monnayeurs e Le Prométhée Mal Enchaîné), sera pensée comme, elle aussi, une possibilité énonciative - c'est-à-dire, comme une possibilité de présence - à partir de l'émergence du connecteur mais. Le centre dans l'énonciation indique l'effort de disloquer le regard de quelques jargons qui habitent les études littéraires (l'auteur ou le narrateur), pour fonder un champ dont l'énonciation pourra être pensée dans ses propres conditions d'émergence. Du reste, penser à ces conditions, c'est surtout ne pas ignorer le point de vue critique, mais l'intégrer à l'espace énonciatif gidéen. Donc, avec la réflexion autour de l'énonciation chez Gide, j'élabore une tentative intégrée de réflexion de mes propres conditions d'énoncer quoi que ce soit dans ce texte.

MOTS-CLÉS : André Gide ; Énonciation ; Espace ; Jean Starobinski ; Critique Littéraire. 


$$
\text { Atlas }
$$

Andr é $\mathbf{G i d e}_{\text {ide }}$ 
Para o meu avô

que esteve aqui que está aqui 


\section{Sumário}

Agradecimentos ............................... 11

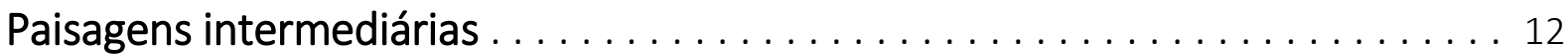

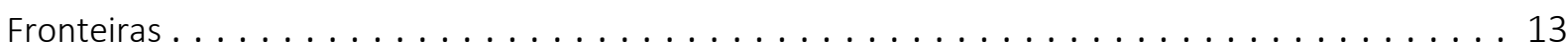

Uma estação . . . ....................................... 24

Eu digo ele, mas esse ele sou eu .................................. 25

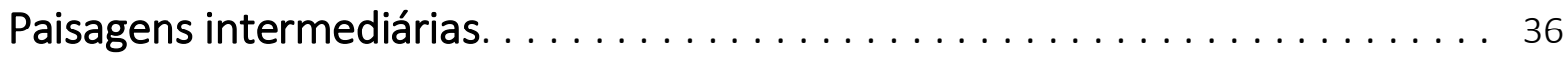

Мара................................................ 37

O espaço que somos...................................... 43

Regiões: Cordilheiras ............................. 46

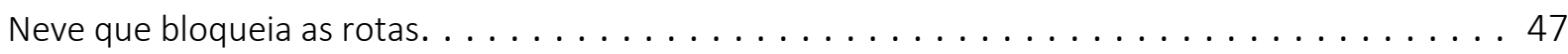

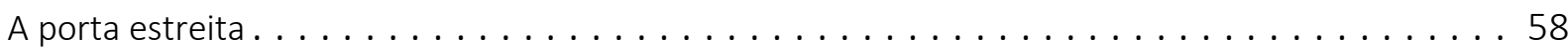

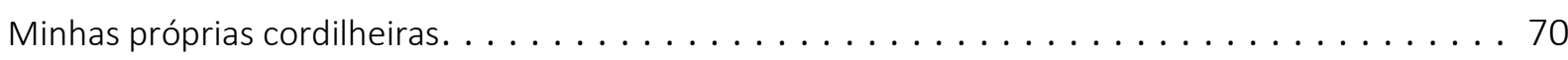

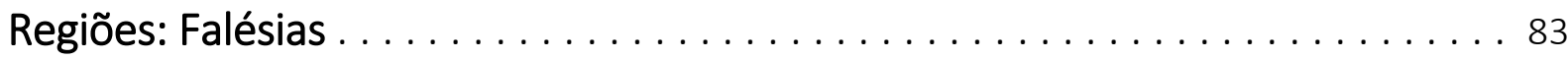

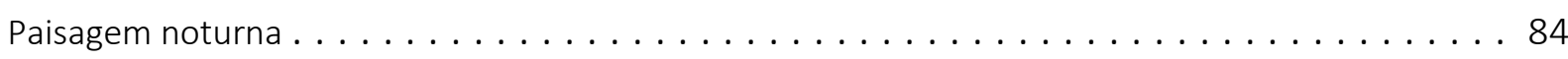

A posição legítima. .................................... 96

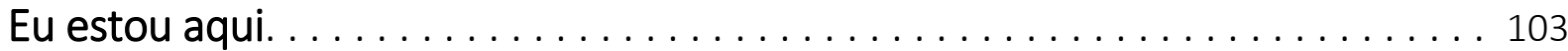

Мара.................................................. 104

Cordilheiras e falésias, cordilheiras e falésias. . . . . . . . . . . . . . . . . . . . 111

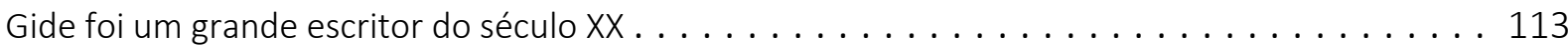

Todos os espaços . . . . . . . . . . . . . . . . . . . . . . . . . . . . . . . . . . . . . . . . 114

Lista de figuras . . . . . . . . . . . . . . . . . . . . . . . . . . . 117

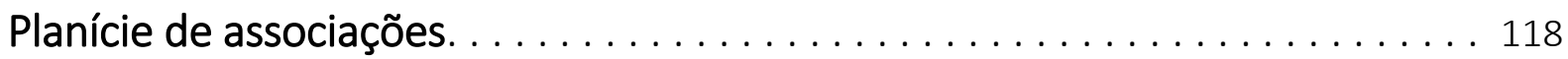




\section{Agradecimentos}

À Verónica Galíndez, que, do terreno horizontal da cumplicidade, me apresentou o verbo pronominal da orientação: orientar-me no espaço e vigiar a minha bússola interior; orientar-me com relação aos outros, com relação a você.

À Betina Bischof, por ter me aberto portas à pesquisa na Iniciação Científica, pelos três anos de uma dedicada orientação (à qual devo muito). À Claudia Pino, por me acompanhar desde o primeiro Gide, pelas indicações na qualificação e pelas farras. Ao Marcos Natali, pela real escuta. Ao Bruno Gomide, pela troca franco-russa. À Erica Durante, pela troca global. À Sheila Ribeiro, pela motivação. Ao Jorge de Almeida, pela bibliografia e por dividir comigo sua leitura de Gide. Ao Mario Viaro, pela amizade. Ao Caio Gagliardi, pelas preciosidades a que me apresentou. À Carla Cavalcanti, pelas reuniões sempre alegres. À Irène Fenoglio, pelos encontros benvenistianos que ainda ressoam. A Pascal Quignard, pelos dois incentivos e pela incontável generosidade.

Ao GELLE, pelas intervenções na construção dessa pesquisa. Ao Criação \& Crítica, por terem me recebido sempre, agradeço pelo contraponto e pelas empanadas. A todos os funcionários do DLM, aos funcionários da seção de pós-graduação da FFLCH e aos monitores e ex-monitores do francês.

À FAPESP, pelo apoio concedido.

Ao círculo secreto: vocês sabem quem são e sabem o peso que têm. Ao Rapha, cúmplice. À Jujuba, minha leitora aberta, criteriosa e minha companheira. À Nah, ouvinte dos arredores desse texto. À Lívia, pela baliza que permitiu o meu mergulho. À Monica, pelas ajudas e encontros. Ao Gu querido. A Naná e Vivi, pela AFF. Ao Edu, pela companhia na revista e na vida. A Paula e Caru, pelas conversas em refeições de no mínimo 7 horas de duração. Ao Emerson, por me colocar constantemente em provação contra mim mesma; uma hora isso recaiu sobre a escrita. Ao Jailson, pelo antagonismo que me localiza, pela companhia, pelo trajeto que também mora aqui.

À minha mãe Glória, à minha avó Conceição, ao meu avô Joaquim. 
Paisagens intermediárias 


\section{Fronteiras}

Ce goût du vivant, ce désir de découvrir des centres d'unification, cette impatience qui empêche Leo Spitzer de se sentir à l'aise dans le champ clos de la linguistique pure, ce sont d'abord les traits vigoureux d'une personnalité, avant d'être les articles d'une méthode. On s'attend à trouver un savant, et l'on trouve un homme ! Ceci a pu être allégué contre l'enseignement de Spitzer, trop unique, trop marqué de passion individuelle pour être un exemple à suivre... Je verrais au contraire quelque chose d'exemplaire dans l'impossibilité, pour le savant, de s'en tenir à sa seule science, dans la fougue qui lui fait rompre les barrières "disciplinaires ", dans l'élan qui transforme le linguiste en stylicien, puis en critique littéraire, et en poète d'idées. Les limites lui pèsent : il y a toujours, pour lui, un isolement à vaincre, une sortie victorieuse à lancer, un contact à trouver. (...) Son approche des œuvres a quelque chose de la conquête amoureuse. ${ }^{1}$

Assistimos aqui a um movimento de atravessar fronteiras descrito por alguém que, ele mesmo, é um explorador de fronteiras: Jean Starobinski, crítico literário e médico psiquiatra, autor do texto acima, observa de modo muito próximo o gesto de Leo Spitzer, cujo trânsito entre estilística e semântica histórica tornou-o muito pouco obediente, contrariamente ao que se pode pensar, aos limites de sua disciplina. Essa descoberta irrompe seguidas vezes no texto de Starobinski, como fontes, como um refrão, como um mesmo escorregador em que são jogadas todas as palavras: a impossibilidade de Spitzer de se conter em uma especialidade

\footnotetext{
1 "Esse gosto pelo vivo, esse desejo de descobrir centros de unificação, essa impaciência que impede Leo Spitzer de se sentir à vontade no campo fechado da linguística pura, são, primeiro de tudo, traços vigorosos de uma personalidade, antes de constituírem regras de um método. Esperamos encontrar um erudito e encontramos um homem! Isso pode ter sido usado para argumentar contra o ensino de Spitzer, demasiado único, demasiado marcado de paixão individual para ser um exemplo a seguir... Eu veria, ao contrário, algo de exemplar na impossibilidade, para o erudito, de se conter em sua ciência exclusiva, na fuga que o faz romper as barreiras "disciplinares", no ímpeto que transforma o linguista em leitor da estilística, depois em crítico literário e em poeta de ideias. Os limites Ihe constrangem: há sempre, para ele, um isolamento a vencer, uma saída vitoriosa a lançar, um contato a encontrar. (...) Sua aproximação das obras tem algo da conquista amorosa". Starobinski, J. "Leo Spitzer et la lecture stylistique", In: La relation critique. p. 67. Essa e todas as traduções dessa dissertação são livres, salvo quando indicado.
} 
e resignar-se à disciplina que contorna o homem e o transforma em savant, em erudito. O que Starobinski entrevê em Spitzer - e que se alia imediatamente a uma descoberta sobre si mesmo - é que, diante do isolamento disciplinar, o homem resiste e segue sua aventura na fronteira das coisas.

Como para Leo Spitzer, como para Starobinski, como para um apaixonado que deseja anular toda distância, a impulsão inicial desse texto se localiza para mim numa contenção primeira, numa distância primeira, no interior da qual posso sentir o peso dos limites. Refirome especificamente aos limites de escrita que circunscrevem gêneros acadêmicos (artigo, relatório destinado a um exame de qualificação, dissertação), cujas convenções mais ou menos vagas, mais ou menos implícitas, desenham uma ilha que exila aquela que escreve de seu continente de enunciação. Escrevendo uma dissertação, me vejo encerrada na especialidade do gênero, um espaço apertado, estou contornada, isolada por ele. Tudo se arquiteta para que eu me transforme em uma não-pessoa que fala: os sujeitos são terceirizados na forma de o presente trabalho, esta pesquisa, etc. Aquilo que leio é transformado naquilo que o texto mostra. Há por baixo da escrita uma ansiedade remanescente de querer desesperadamente neutralizar e como que polir a linguagem, desarmá-la de toda singularidade que Ihe seja própria, purificá-la de seus acidentes e de suas impropriedades - como se essas coisas jamais tivessem pertencido à sua essência de linguagem ${ }^{2}$. À linguagem resta apenas ocupar-se com o nivelamento de seu próprio terreno,

\footnotetext{
${ }^{2}$ Essa ansiedade remanescente a que me refiro corresponde à divisão que Michel Foucault encontra nos dois empregos da linguagem possíveis a partir do espaço epistemológico que ela, por assim dizer, habita no século XIX: “Ce nivellement du langage qui le ramène au pur statut d'objet se trouve (...) compensé de trois manières. D'abord par le fait qu'il est une médiation nécessaire pour toute connaissance scientifique qui veut se manifester comme discours. Il a beau être lui-même disposé, déployé et analysé sous le regard d'une science, il resurgit toujours du côté du sujet qui connaît - dès qu'il s'agit pour lui d'énoncer ce qu'il sait. De là, deux soucis qui ont été constants au XIXe siècle. L'un consiste à vouloir neutraliser et comme polir le langage scientifique, au point que, désarmé de toute singularité propre, purifié de ses accidents et de ses impropriétés - comme s'ils n'appartenaient point à son essence -, il puisse devenir le reflet exact, le double méticuleux, le miroir sans buée d'une connaissance qui, elle, n'est pas verbale." Les mots et les choses. p. 309. "Esse nivelamento da linguagem
} 
desprovendo-se de qualquer interferência estranha à sua natureza plana, de qualquer ruptura ou de qualquer montanha. Tudo o que se afirme na planície impessoal da linguagem deve passar pelo crivo da palavra alheia (a citação que unicamente autoriza).

Quem de fato está falando aqui?

Esse inconveniente, que sinto agora com tanta intensidade, é fruto de uma incompatibilidade fundamental entre esse plano de dissertação e a minha vida. E o descontentamento existe justamente porque a vida, de uma forma ou de outra, quer desaguar no texto, não se trata de um iceberg que separa e paralisa a água, mas de um mesmo rio correndo sempre. A conquista, o magnetismo amoroso que desperta um pensamento adormecido em escrita. É impossível fingir que as aulas a que assisti, sentada em cadeiras em forma de círculo ou enfileiradas todas num mesmo sentido, a presença ou eventualmente a proximidade ou mesmo o contato, os livros que inesperadamente desorganizaram minha fila de leituras, os filmes e uma troca desembaraçada de e-mails não me constituem ${ }^{3}$ no momento em que estou dizendo, numa redundância (o pronome eu é uma máscara, mas também uma redundância), eu nesse texto. Bien avant de communiquer, le langage sert à vivre ${ }^{4}$, lembranos Émile Benveniste num texto sobre a forma e o sentido na linguagem.

\footnotetext{
que a reduz ao puro estatuto de objeto encontra-se (...) compensado de três maneiras. Primeiro, pelo fato de ela ser uma mediação necessária para todo conhecimento científico que pretende manifestar-se como discurso. Ainda que ela própria seja posicionada, desdobrada e analisada sob o olhar de uma ciência, ela ressurge sempre do lado do sujeito que busca conhecer - desde que se trate, para ele, de enunciar o que sabe. Daí duas preocupações que foram constantes no século XIX. Uma consiste em querer neutralizar e como que polir a linguagem científica, a tal ponto que, desarmada de toda singularidade própria, purificada de seus acidentes e de suas impropriedades - como se não pertencessem à sua essência -, pudesse tornar-se o reflexo exato, o duplo meticuloso, o espelho sem nebulosidade de um conhecimento que, esse não é verbal". As palavras e as coisas. Trad. Salma T. Muchail com adaptações minhas. p. 319.

${ }^{3}$ Semelhante ao que Denis Wood identifica como uma segunda fonte de energia crítica da qual sua dissertação provém: "These good things, these moments of shimmering light and warmth, these instances of constructive insight, these examples of hospitality, support, aid: these constitute the second source of critical energy, no less critical than the first". "Essas coisas boas, esses momentos de luz resplandecente e de acolhimento, esses casos de percepção construtiva, esses exemplos de hospitalidade, apoio, ajuda: tudo isso constitui a segunda fonte de energia crítica, não menos crítica do que a primeira". "Acknowledgments", In: I don't want to, but I will. p. IV.

4 "Antes de comunicar, a linguagem serve para viver". Benveniste, E. "La forme et le sens dans le langage ", In : Problèmes de linguistique générale, 2. p. 217.
} 
Mas como um texto olha para trás? Porque, no momento em que se escreve, o texto já está avançando, correndo, já se entrou nele de alguma forma ${ }^{5}$. Seja de forma brusca, tropeçando num degrau, seja de forma conduzida, através de um corredor.

Há algum tempo, participei da editoria de uma revista acadêmica cujo dossiê temático era sobre fronteiras. Num encontro com os dois outros editores a respeito da redação do editorial, aconteceu uma coisa ao mesmo tempo muito banal e muito determinante: enquanto cada um de nós lia um artigo do número para os outros, em voz alta, uma das editoras anotava numa folha certas expressões associadas ao tema central, que apareciam durante a leitura. Ao fim da reunião, havíamos construído uma grande nuvem de noções que orbitavam em torno dos textos, trajetos, escadas caracol que levavam a eles. 0 aspecto determinante é que nos apegamos de tal modo a essa forma de pensar em nuvem, que abandonamos logo a ideia de um editorial de apresentação como um texto ligado por início, meio e fim, para criar um editorial espalhado, que fosse ele mesmo uma nuvem ou um mapa.

O aspecto determinante é ainda que o editorial, por si, não esgotou essa forma de pensar em mapas, em mim. Pelo contrário, ao escrever o editorial, só estávamos atiçando o fogo. Minha presente utopia de pesquisa é precisamente uma pesquisa que se faça em nuvens. Ou, de forma relativizada, que nunca abandone seu estágio inicial de brainstorming.

\footnotetext{
${ }^{5}$ Sheila Ribeiro, na introdução de sua tese de doutorado, afirma acuradamente que "sem origem, o sujeitoobjeto dessa pesquisa começa "do meio".". Ribeiro, S. C. Congruências absurdas // corpomídia da metrópole comunicacional. p. 28.
} 
Ou, de forma ainda mais relativizada, que conserve, independentemente de sua fase adulta, qualquer coisa de um lampejo que deixe reluzir a imaturidade de um brainstorming.

Numa entrevista sobre o filme Encounters at the end of the world, um documentário sobre a estação de pesquisa McMurdo, localizada na Antártida, o cineasta Werner Herzog justificou a escolha de sua locação com uma fotografia da expedição do guitarrista e mergulhador Henry Kaiser por aquele continente. Ao deparar-se com a foto pela primeira vez, Herzog foi tomado por um impulso - até inconsequente, se se pensa sobre isso - de dirigir-se com sua equipe de filmagem à Antártida.

Acredito que a exploração da crítica literária possa se lançar a uma mesma ousadia e a uma mesma aventura: uma partícula do texto se atrita com a minha leitura, produzindo um ruído cuja origem me é de todo desconhecida; intuo que há algo ali, mas não sei absolutamente se, entrando por essa mínima fresta, sairei num corredor, numa trilha estreita ou sequer num espaço em que eu possa ficar em pé sem me curvar. Mas essa intuição como que espectral é a minha foto de mergulhador, que me lança num potencial lugar de peregrinação. 


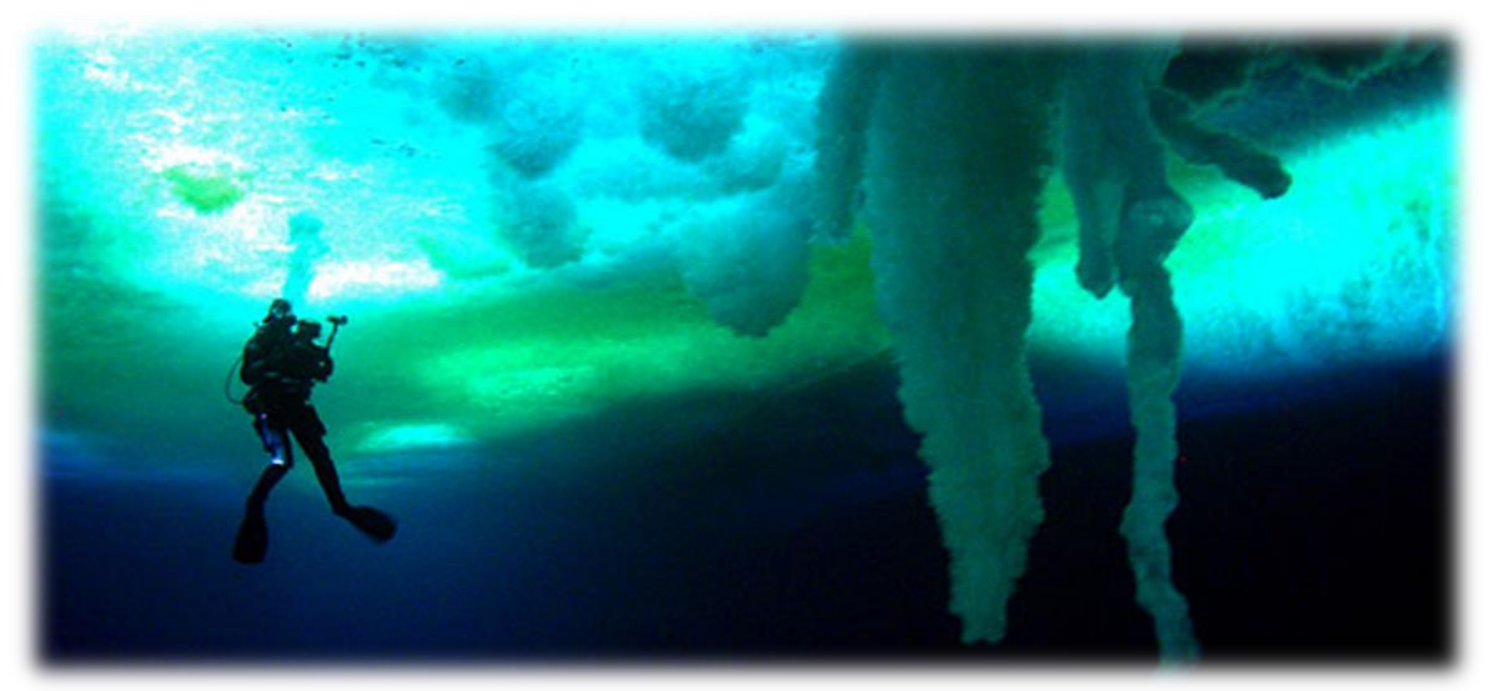

(Meu primeiro encontro com Gide pode ser dividido em duas partes, duas paradas ou duas pequenas estações: a primeira delas teve lugar depois da leitura de Paludes, produzindo em mim uma atração diluída e inconsistente, que se fechou de modo provisório com um trabalho de final de curso, na graduação. A segunda parte desse primeiro encontro veio somente depois de um intervalo de um ano e meio em relação a Paludes, determinando, em compensação, uma relação que se projetava mais, cujo norte era sem dúvida mais apaixonado e também mais perdido, quando descobri Les Faux-monnayeurs.

Na primeira parte do primeiro encontro, Gide era na minha perspectiva simplesmente um objeto: para aquele trabalho de final de curso, eu analisei Paludes munida de um aparato crítico que, como uma cerca que contorna uma propriedade, firmava um destino para minha escrita. Grande parte das leituras que eu fazia naquele momento punha as minhas ideias em movimento dentro de um espaço contornado pela palavra imanência (a obra literária é, na formulação de Theodor W. Adorno, conteúdo social sedimentado ${ }^{6}$.

\footnotetext{
${ }^{6} \mathrm{~A}$ formulação aparece reiteradas vezes na reflexão de Adorno e configura um pressuposto para as suas análises. Podemos encontrá-la, por exemplo, no ensaio "Palestra sobre lírica e sociedade", In: Notas de literatura I. Há
} 
A coordenada da imanência impunha-se, pela forma através da qual eu me fixava em relação a ela, de maneira mais refratária aos indícios de minha presença enunciativa sobretudo porque, diante dessa coordenada, o verbo dentro do qual encontrei meu posicionamento foi fixar-me. Essa estagnação surgiu - penso retroativamente - por conta de uma relação com o aspecto objetivo da História que a imanência implica e que nunca fui capaz de estabelecer. Sendo assim, eu estaria fadada a repetir dados históricos que outros já tinham encontrado e interpretado em meu lugar, de modo mais eficiente do que eu, certamente de modo mais robusto. Contudo, não se tratava, por essa razão, de uma situação em que aquilo que chamei de presença enunciativa originasse uma refração completa face à teoria. A ideia de uma imanência do objeto dá a medida dessa refração ${ }^{7}$. Mas a questão não corresponde a uma recusa de minha parte em reconhecer a presença de conteúdo social sedimentado na forma de uma obra de arte. Trata-se de algo bem mais simples e até mais irrelevante do que isso, de certo ponto de vista, trata-se inclusive de algo que não chega a se constituir de forma opositiva. Eu sentia que naquele edifício teórico não haveria espaço para o meu desejo de traçar um itinerário com a escrita - cuja desorientação, cuja trajetória, cuja irresponsabilidade me aliciam de imediato.

De modo que, nesse primeiro contato com Gide, nenhum fogo aceso senão um lampejo, uma fagulha. No ano seguinte, ainda na graduação, a plenitude do primeiro encontro adveio por acaso, uma vez que Gide não estava previsto em nenhuma relação bibliográfica das disciplinas que eu cursava. Numa das primeiras aulas de um curso de literatura francesa, no

também uma interpretação desse conceito no texto de Antonio Candido sobre a leitura que Roger Bastide faz de Machado de Assis, que li no primeiro ano de faculdade e que funcionou como uma ponte para que eu compreendesse o conceito de imanência. "Machado de Assis de outro modo", In: Recortes.

${ }^{7}$ Além de que para o próprio Adorno, por exemplo, a subjetividade do leitor cumpre um papel fundamental de mediação na construção crítica. Essa é a tese principal enunciada em "O ensaio como forma", op. cit. 
entanto, recebemos uma cópia de três páginas localizadas no meio de Les Faux-Monnayeurs, de uma cena em que um grupo de personagens promove uma discussão confusa e intelectualizada sobre a forma romance, na qual eu via muita ironia. Para o curso, tratava-se apenas de entrar em contato brevemente com um livro de Gide que, da perspectiva escolhida, tinha aberto portas para os romances que iríamos efetivamente ler:

\author{
Voyage au bout de la nuit de Louis-Ferdinand Céline \\ Tropismes de Nathalie Sarraute \\ La modification de Michel Butor \\ La vie mode d'emploi de Georges Perec \\ Tous les matins du monde de Pascal Quignard
}

Mas depois daquelas três páginas xerocadas eu não quis mais ler nada disso, eu não quis nem mais ler Virginia Woolf - a quem eu havia dedicado até então minha primeira experiência de pesquisa - mas só, unicamente, Les Faux-Monnayeurs.

Fui então subjugada a algum redirecionamento, contornei alguma esquina ou desci para o vale de alguma montanha. Vivi uma transformação esquisita, cujo sintoma se deu por meio dessa troca de autores. Desde então, atravessei outras pontes, contornei outras esquinas, desci para o vale de muitas montanhas. Mas todo esse movimento deambulatório se manteve circunscrito dentro de uma mesma esfera - André Gide - em que os livros são, cada um: um país, uma península, um rio. $\mathrm{E}$ por vezes mesmo um continente inteiro, um arquipélago inteiro).

Starobinski diz, no texto "La relation critique", que a investigação crítica é como $a$ viagem daqueles que partem por partir: 
L'œuvre critique, certes, peut très honorablement s'astreindre à l'application d'un programme préétabli. Mais il vaut mieux qu'elle ressemble au voyage de ceux " qui partent pour partir », sans savoir où la pérégrination les mènera. Il faut tenter de passer d'un plan méthodologique à un autre, même si l'on possède une particulière compétence ou si l'on a une prédilection pour l'un d'entre eux. Or ce déplacement-là n'est régi lui-même par aucune méthode rigoureuse. Je souhaiterais que soit faite ici la part d'un choix, mais d'un choix qui se garde de l'irrespect et de l'arbitraire ${ }^{8}$.

A crítica se constrói na forma de um trajeto, que implica em algum sentido uma instabilidade - um processo movediço - no qual o convívio prolongado com o texto se oferece na imagem de um deslocamento. Starobinski dá muita ênfase a termos tais como trajeto e viagem, e essa ansiedade itinerante guarda uma rejeição primeira em predispor a determinação de um método específico ${ }^{9}$ ao próprio ato de ler - que abre portas, ao invés de abrigar-se inerte, cercado, no interior de uma só casa fechada. A leitura é, assim, a própria aventura.

\footnotetext{
8 "A obra crítica, é certo, pode de forma honorável se restringir à aplicação de um programa pré-estabelecido. Mas é preferível que ela se pareça com a viagem daqueles "que partem por partir", sem saber onde a peregrinação os levará. É preciso tentar passar de um plano metodológico a outro, mesmo se possuímos uma particular competência ou se temos predileção por um deles. Todavia esse deslocamento não é regido por nenhum método rigoroso. Eu desejaria que fosse realizada aqui uma escolha, mas uma escolha que conserve o desrespeito e o arbitrário". "La relation critique", Op. Cit. p. 35-6.

${ }^{9} \mathrm{Na}$ tentativa de traçar uma correlação, posso dizer que a imanência designa um método crítico. Mas é claro, e isso é fundamental, que a ideia de um método adquire um peso outro se pensarmos a sua implicação num contexto francês (ainda que Starobinski tenha realizado sua formação na Suíça, a sua reflexão é quase inteiramente baseada em autores franceses). Para as diversas práticas críticas realizadas no Brasil, seria preciso especificar que tipo de métodos estariam em jogo, e as associações possíveis com paradigmas franceses. De todo modo, não me sinto ausente, em minha experiência com algumas disciplinas da Universidade de São Paulo, da seguinte afirmação de Starobinski: "Il faut se rappeler que toute méthode précise stabilise le plan auquel elle s'applique adéquatement. Mieux elle spécificiera son langage, et plus seront prédéterminés les faits qu'elle saisira et la manière dont ceux-ci seront coordonnés. Les éléments qu'elle confrontera seront en rapport d'homogénéité et de congruence. L'investigation ayant défini son angle d'approche, il arrive rarement qu'elle ne trouve quelque chose qui ressemble à ce qu'elle cherchait, offert au langage qui était tout préparé pour le décrire". "É preciso se lembrar de que todo método preciso estabiliza o plano ao qual ele se aplica adequadamente. Melhor ele especificará sua linguagem, e mais serão pré-determinados os fatos que ele irá abarcar e a maneira pela qual estes últimos serão coordenados. Os elementos que ele confrontará estarão em relação de homogeneidade e de congruência. Para a investigação, assim que define seu ângulo de aproximação, é raro que não encontre alguma coisa que pareça com aquilo que ela procurava, oferta à linguagem que estava de todo preparada para a descrever". Ibid. p. 33.
} 
Mas não uma aventura solitária. É preciso, primeiro de tudo, jogar para longe as ideias de heróis que povoam ainda o horizonte, as hierarquias de gênios acadêmicos, os rankings, as escadarias intelectuais. Essa empreitada, pela qual sou por vezes levada e que por vezes conduzo, tem origem na escrita de exploradoras e aventureiros que me acompanham ainda hoje, agora. Para Jacques Rancière ${ }^{10}$, as interpretações, o ato de traduzir a palavra do outro com o seu próprio pequeno artesanato de palavras, é antes de tudo produzir uma ação no mundo. Gostaria de mencionar especialmente os trabalhos de Lívia C. Gomes ${ }^{11}$, Lygia Winter $^{12}$, Sheila Ribeiro ${ }^{13}$, Heloisa Pait ${ }^{14}$, Denis Wood $^{15}$, Viviane Pereira ${ }^{16}$, além do trabalho em curso de Leda Cartum ${ }^{17}$. Essas pessoas se propuseram, cada uma a seu modo e dentro de suas respectivas instituições, a andar pisando em cima dos pontilhados que contornam as

\footnotetext{
${ }^{10}$ Essa ideia perpassa toda a construção de $O$ mestre ignorante - cinco lições sobre a emancipação intelectual, mas também aparece em Politique de la littérature : " les interprétations sont elles-mêmes des changements réels, quand elles transforment les formes de visibilité d'un monde commun et, avec elles, les capacités que les corps quelconques peuvent y exercer sur un paysage nouveau du commun ". "As interpretações são elas próprias mudanças reais, quando transformam as formas de visibilidade de um mundo comum, e, com elas, as capacidades que corpos quaisquer possam exercer sobre uma paisagem nova do comum". p. 39.

11 "A escrita literária é política e age no mundo porque seus artifícios leem o leitor, silenciando a tagarelice repetitiva de suas ideias feitas e questionando ou corroendo as semelhanças discursivas que se repetem na violência do habitus". Gomes, Lívia Cristina. Machado com Flaubert ou a política da escrita. Dissertação (Mestrado) - Faculdade de Filosofia, Letras e Ciências Humanas da Universidade de São Paulo. São Paulo, 2011. p. 12.

12 Winter, L. M. Escritas do suporte. Tese (Doutorado). Campinas, 2012.

${ }^{13}$ Ribeiro, S. C. Congruência absurda // corpomídia da metrópole comunicacional. Tese (Doutorado). São Paulo, 2014.

${ }^{14}$ Refiro-me mais precisamente a seu relato de experiência docente em que prevalece o caráter, não de hierarquia acadêmica, da transmissão unilateral de um bloco de conhecimento, mas do fundamental encontro entre pessoas, a ideia de uma pequena comunidade que se forma em torno de uma atividade comum e que produz, pouco a pouco, sentido. "As alunas e os contos: a narrativa curta brasileira num curso de escrita criativa nos Estados Unidos”, In: Revista Brasileira de Literatura Comparada, №. 15, 2009.

${ }^{15}$ Op. Cit.

${ }^{16}$ Pereira, Viviane Araújo Alves da Costa. lonesco crítico em: "Da teoria da derrisão à derrisão da teoria". Tese (Doutorado). USP - São Paulo, 2014.

${ }^{17}$ Atual mestranda da Área de Estudos Linguísticos, Literários e Tradutológicos em Francês, da FFLCH-USP. Todas as propostas citadas foram aquelas a que pude ter acesso e que mais dialogaram com minha experiência de compor uma dissertação. Vejo que atualmente se ergue em diversas universidades, não só brasileiras, uma série de questionamentos em torno das condições de enunciação que dão lugar a uma pesquisa, e espero, no prosseguimento de minha trajetória acadêmica, poder dialogar com mais pesquisadores nesse sentido. Agradeço a Marcos Natali pelas frutíferas indicações que chamaram minha atenção para esse ponto.
} 
formas acadêmicas. Elas quiseram andar por esses pontilhados e perguntar para essas formas: o que vocês têm a me dizer? 
$U_{\text {ma estação }}$ 


\section{Eu digo ele, mas esse ele sou eu ${ }^{18}$}

André Gide foi um grande escritor do século XX. Fiquei marcada com a condenação que ouvi numa aula de literatura a respeito do trabalho de um aluno que começava dessa forma. O pressuposto para essa advertência era que a generalização levava o aluno a construir um muro entre ele mesmo, na posição de leitor, e o livro: repetindo esse clichê, o autor do trabalho estava fugindo de Gide e da responsabilidade de ler. É claro que, diante de tamanha ênfase, o meu impulso foi de imediato o de não me deixar levar por nenhum subterfúgio semelhante. Tomei distância de toda postura que pudesse corresponder a essa fuga e quis assumir enfaticamente a responsabilidade por minhas leituras. Ademais, o repertório teórico que me alimentava - como a "Relação crítica" de Starobinski - concentrava-se igualmente na vigilância contra lugares-comuns da crítica.

Mas a escrita armazena destinos próprios, para os quais, na condição de marinheira ancorada na ilha da vontade e da autoria, nunca se está suficientemente precavida. O barco vai com toda certeza se descontrolar; o real desencanto do barquinho empurrado pela correnteza. André Gide foi um grande escritor do século XX: repetindo eu mesma esse clichê, intuo de seu enorme vazio (além do eco da advertência da aula de literatura) o peso de um julgamento de Roland Barthes, para quem o clichê - em suas palavras, a Doxa - é uma repetição morta, que não vem do corpo de ninguém - senão, precisamente, do corpo dos Mortos $^{19}$. A repetição sem vida é uma aterradora e a cada vez surpreendente falta de alguém.

\footnotetext{
${ }^{18}$ A frase é de Gide : « Je dis « il », mais ce « il » c'est moi. » 15 de maio de 1949. Journal, Vol II. p. 1073.

19 « La Doxa est une répétition morte, qui ne vient du corps de personne - sinon peut-être, précisément, de celui des Morts ». Roland Barthes par Roland Barthes. p. 85.
} 
Mas será isso mesmo? Seria mesmo possível dizer que não há ninguém, seria mesmo possível, através do clichê, amparar-se em uma oposição excludente entre presença e ausência?

Esse questionamento foi aquilo que primeiro de tudo dirigiu o meu interesse por Gide: suspeitei que ele repetia clichês criando na repetição um espaço que pudesse habitar, no qual pudesse estar presente. Essa suspeita se materializou no meu projeto inicial com a possibilidade de pensar uma espécie de repetição ao mesmo tempo subversiva e produtiva do clichê amoroso em L'Immoraliste ${ }^{20}$. E, submersa ainda nessa suspeita - porque a pesquisa, por maior que tenha sido a curva em relação ao início, nunca rompe consigo mesma, com algo como um si mesma, uma coisa que não se reduz a nenhuma outra e um tormento que retorna com insistência e obstinação -, vejo, no mais pleno deserto do lugar-comum, uma silhueta presente em Gide foi um grande escritor do século $X X$, que é em primeiro lugar e, muito precisamente, Gide. Aqui não se pode ter pressa, apelar para a radicalidade de que no clichê só haja uma enorme e surpreendente ausência. A cada vez que o clichê é repetido, algo ressoa, ainda que ressoe numa sala vazia, ainda que ressoe só uma lembrança bem diluída ${ }^{21}$. Alguém está ali.

Observemos de mais perto que posição Gide, esse primeiro sujeito, o sujeito evidente, toma nessa frase. O verbo foi propõe aqui uma travessia do nome Gide para a designação que

\footnotetext{
${ }^{20}$ Tudo começou com o trecho citado na página 73 dessa dissertação. Tratava-se de uma repetição que naquele momento eu imaginava provida de um corpo. Depois, pouco a pouco, fui abandonando essa nomenclatura, uma vez que eu via nela o risco de me distanciar demasiado daquilo que me motivava. Isto é, falar sobre corpo, cristalizá-lo demais a partir de sua tradição teórica, andar primeiramente em volta dele e depois para cada vez mais longe, esgotar ao longe o ímpeto da presença (que está, possivelmente, não nas ideias, não no objeto, não nas referências, e sim no ritmo daquilo que se lê, daquilo que se escreve).

${ }^{21}$ Como na primeira temporada do seriado American Horror Story, cujo subtítulo é Murder House. Essa casa assombrada, para a qual uma família acaba de se mudar, está aparentemente vazia, mas é também um aglomerado de fantasmas de todas as pessoas que já moraram ali e que morreram ali. É um grande como viver junto entre mortos e vivos, um acúmulo de clichês do cinema de terror estadunidense, mas também um experimento com as possibilidades e nuances da presença.
} 
Ihe é atribuída, um grande escritor do século XX. Essa trajetória corresponde propriamente ao sentido de um verbo de ligação, que vincula o sujeito às suas características. No verbo de ligação, não há ação, degrau, acidente, ou qualquer percalço que se instale: a passagem de uma coisa à outra ocorre de forma direta, quase como se o verbo se transformasse em uma transparência, em um vidro: Gide foi um grande escritor do século XX. Mas o que significa essa existência transparente? O verbo de ligação é algo que, ainda que invisivelmente, se impõe no meio do percurso. O sujeito passa por esse vidro com o olhar, aspirando com impaciência àquilo que o espera na sua frente. Mas ele não chega realmente a atravessar nada. Ele permanece ali parado, olhando para frente, mas observando ao mesmo tempo o seu próprio reflexo, que está ele também sinalizado no vidro. Pode não haver ação alguma num verbo de ligação - o sujeito está parado, olhando -, mas há por certo algo como uma retroação nesse indício de reflexo no vidro. Ele olha para o seu predicado, e olha ao mesmo tempo para si. Ele nunca chega até o predicado, mas olha para si.

Gide permaneceu assim: contemplando a atribuição de um grande escritor que fora colocada à sua frente, ao mesmo tempo que observava a si mesmo. O seu si mesmo esteve, desde o início, fora da atribuição, em algum outro lugar. Para Alain Goulet, a autoria de Gide é uma autoria em abismo: on est (...) loin d'un rêve mégalomaniaque d'auto-glorification de l'auteur. L'auteur en abyme relève bien plutôt d'un exercice d'interrogation, parfois d'auto dérision ou même d'auto flagellation ${ }^{22}$. O autor não se autoglorifica, mas olha para si, dirige uma interrogação para si mesmo, pratica algo como uma autoderrisão, e por vezes mesmo a autoflagelação. Isso quer dizer que, em Gide foi um grande escritor do século XX, é preciso

\footnotetext{
22 “Estamos (...) longe de um sonho megalomaníaco de autoglorificação do autor. $\mathrm{O}$ autor em abismo diz muito mais respeito a um exercício de interrogação, por vezes de autoderrisão ou mesmo de autoflagelação." "L'auteur mis en abyme (VALÉRY et GIDE)", In : Lettres françaises. №. 7. p. 56.
} 
considerar com certa desconfiança a travessia clara e limpa entre o nome e o seu predicado, e talvez seja esse o malogro da rapidez com a qual um clichê faz sentido. Há algo impedindo um processo fusional entre o sujeito e o seu predicado, invocando uma separação, que no entanto não determina que Gide seja o oposto daquilo. Mas, simplesmente, que se pode olhar com desconfiança para a fusão, que não há simplesmente um sujeito e simplesmente um objeto.

Tentemos, em primeiro lugar, nos localizar no que concerne à atribuição externa de um grande escritor. Não tenho a intenção, é claro, de desdobrar para todos os lados as razões que permitiram que Gide representasse essa figura, vestisse essa máscara. Desejo, pontualmente, atentar para um aspecto que o fez parecer grande diante do século e diante de si mesmo: a sua participação, por volta de 1909, na formação da Nouvelle Revue Française $(N R F)$, uma das mais imponentes revistas literárias francesas e que deu origem à célebre editora Gallimard. A NRF era, em seu grupo inicial, um lugar de discussão, de convergência de tendências literárias, de leitura dos contemporâneos e também, é evidente, de destaque para aqueles que dela participavam. Mas o que me interessa especialmente aqui é que, acima de tudo, a ideia de um encontro fundava o ponto de coesão dessa revista:

La Nouvelle Revue Française (...) ne se voulait pas une chapelle, et son éclectisme, affirmé dès 1909, n'admettait de bornes que celles de I'honnêteté intellectuelle (...) ; elle n'était rien moins qu'une école et, en fait de manifeste, son premier numéro s'était contenté de Considérations fort générales de Schlumberger, et d'une petite gerbe de citations qui traduisaient surtout, en matière esthétique, le goût du travail et de la mesure, et une certaine méfiance à l'endroit de l'inspiration, de 
l'improvisation, des séquelles de la facilité romantique... La cohésion de l'équipe de la N.R.F. avait été celle d'un groupe d'amis qui s'appréciaient, s'estimaient dans leur différences. ${ }^{23}$

Inaugurar a NRF não significava necessariamente criar um movimento de circunscrição fechada, em que todos se mantivessem dentro de uma uniformidade intelectual. Embora houvesse, de modo geral entre os seus membros, uma certa desconfiança voltada para os lados da inspiração, da improvisação, das sequelas da facilidade romântica, a revista não pressupunha profundas identificações de ordem estética, tampouco a imposição de diretrizes para a criação e para a crítica nela praticadas. Não se tratava do estabelecimento de um programa crítico. Nem de manifestos ou de sistemas de criação, luta. Tratava-se, isto sim, da coesão que emanava de um grupo de amigos, da coesão de um encontro. A despeito dos rumores em torno dos impulsos autoritários de Gide para com a revista, havia ali algo de uma comunidade instaurada no contorno de uma atividade comum. Essa é a mesma ideia que Auguste Anglès, em seu estudo sobre a formação da NRF, assume como ponto de partida. Para ele, aliás, a organização coletiva da NRF cruza em algum momento uma condição fundamental, da qual Gide se valia na sua própria atividade. Para o crítico, a escrita de Gide sempre se sustentou na projeção de uma coletividade, ou ao menos na projeção de uma relação ${ }^{24}$.

\footnotetext{
23 “A Nouvelle Revue Française (...) não pretendia ser uma igreja, e seu ecletismo, afirmado já em 1909, só admitia os limites da honestidade intelectual (...); ela não era nada menos do que uma escola e, a título de manifesto, seu primeiro número se contentou com as Considérations bastante gerais de Schlumberger, e com um pequeno punhado de citações que traduziam sobretudo, em matéria estética, o gosto pelo trabalho e pela medida, e certa desconfiança voltada para os lados da inspiração, da improvisação, das sequelas da facilidade romântica... A coesão da equipe da N.R.F. era a de um grupo de amigos que se apreciavam, se estimavam em suas diferenças". Martin, C. Gide. p. 139.

${ }^{24}$ Anglès, A. André Gide et le premier groupe de La NRF. La formation du groupe et les années d'apprentissage (1890-1910). p. 14.
} 
Posso exemplificá-lo com uma imagem que o próprio Anglès emprega: as dedicatórias. As amizades de Gide, exibidas orgulhosamente nas dedicatórias de seus livros, não sugerem apenas uma estima especial do autor pelo destinatário da dedicatória. Elas são algo além, sinalizam uma importância além: a de que, na verdade, não há ali a ideia de um destinatário. Os nomes que aparecem nas páginas iniciais de Gide não se projetam rumo $a$ alguém - como um presente, um resultado que se oferece com devoção - mas apenas fazem questão de marcar o itinerário da viagem de ter escrito o livro na companhia de uma pessoa. É, em algum sentido, escrever o próprio nome numa árvore, o que não quer dizer nada além de eu estive aqui. As dedicatórias são o você esteve aqui de Gide (elas são a própria imanência). Isso aparece na dedicatória de Les Faux-monnayeurs:

\author{
A Roger Martin du Gard \\ je dédie mon premier roman \\ en témoignage d'amitié profonde
}

A. G. $^{25}$

Roger Martin du Gard, escritor contemporâneo a Gide e seu grande amigo, influenciou Gide em muitos aspectos, e essa influência é tomada normalmente como o significado dessa dedicatória. Segundo Henri Godard:

Les faux-monnayeurs n'aurait pas existé, en tout cas le roman ne serait pas ce qu'il est, sans l'intimité établie pendant ces années entre Gide

\footnotetext{
25 "A Roger Martin du Gard eu dedico o meu primeiro romance, como testemunho de uma amizade profunda". Les Faux-monnayeurs. p. 9.
} 
et Roger Martin du Gard. En celui-ci, Gide (...) trouve (...) la vivante incarnation, dans ce XXe siècle qui en est déjà à sa deuxième décennie, de la tradition romanesque qui, au XIXe, a pris force de modèle si ce n'est de canon, et contre laquelle, depuis Paludes en 1985, lui-même n'a cessé de s'inscrire. C'est ce modèle que Roger Martin du Gard perpétue, intelligemment et avec un talent estimable, en se réclamant de Tolstoï. ${ }^{26}$

Há, sob a perspectiva de Henri Godard, uma espécie de modelo de romance cujo legado remonta ao século XIX, e ao qual Martin du Gard se alia, no desejo de prolongá-lo; Roger Martin du Gard é a encarnação viva dessa tradição romanesca que tomou a força de um modelo e de um cânone. Para Gide, o romance era um sistema pronto, fechado, artificial, que era preciso tornar menos petrificado. O romance tornou-se para ele, assim, um grande eixo, uma base para ser subvertida (voltarei a falar sobre isso mais tarde). Roger Martin du Gard, sendo aquele que materializava o desejo por uma incorporação plena da maneira tradicional de escrever romances, funcionará como uma espécie de contraponto de Gide ${ }^{27}$.

Entretanto, na dedicatória de Les Faux-monnayeurs, du Gard é citado, não como uma fonte intelectual para a elaboração desse primeiro romance, tal como sugere Henri Godard, e sim como um eixo afetivo: a citação está ali para testemunhar uma amizade profunda. O que é mais comumente chamado de influência toma corpo em Gide como a escrita que, constantemente, das mais variadas formas, ressoa outras presenças, a presença mesmo de suas companhias.

\footnotetext{
26 "Les faux-monnayeurs não existiria, ou, de todo modo, o romance não seria aquilo que é, sem a intimidade estabelecida durante estes anos entre Gide e Roger Martin du Gard. Neste, Gide (...) encontra (...) a viva encarnação, nesse século XX que já está em sua segunda década, da tradição romanesca que no século XIX se fortificou como um modelo, senão como um cânone, e contra a qual, desde Paludes, em 1985, ele mesmo não deixou de se colocar. É esse modelo que Roger Martin du Gard perpetua, de modo inteligente e com estimável talento, reivindicando para si a influência de Tolstói". Godard, H. Le roman modes d'emploi. p. 96.

${ }^{27}$ De maneira mais geral, Martin du Gard era, segundo Claude Martin, uma espécie de polo positivo, racionalista de Gide, no qual ele encontrava um eixo para suas próprias oscilações. Martin, C. op. cit. p. 140.
} 
É preciso andar um pouco para trás e mencionar uma outra coisa, sobre a qual Gide mesmo não se cansa de falar, e que diz respeito ao ser de diálogo que ele acredita ser:

Comment expliquer que cette cohabitation en moi des extrêmes n'amenât point tant d'inquiétude et de souffrance, qu'une intensification pathétique du sentiment de l'existence, de la vie ? Les tendances les plus opposés n'ont jamais réussi à faire de moi un être tourmenté ; mais perplexe - car le tourment accompagne un état dont on souhaite de sortir, et je ne souhaitais point d'échapper à ce qui mettait en vigueur toutes les virtualités de mon être ; cet état de dialogue qui, pour tant d'autres, est à peu près intolérable, devenait pour moi nécessaire. ${ }^{28}$

O conflito existente no estado de diálogo é precisamente aquilo que leva Gide a acreditar em uma intensificação do sentimento de existência, de vida. Embora ele tenha inúmeras vezes formulado como essa coexistência de tendências opostas é para ele tão fundamental, há aqui um detalhe que aponta para mais longe, que é a fusão que ele realiza entre o seu estado de diálogo e o sentimento de vida que o estado de diálogo desperta. Como se o diálogo fosse inerente à ideia que Gide faz da vida, o pressuposto de sua existência, segundo aquilo que ele pôde formular.

Vejo aqui algo para o que Alain Goulet apontou certa vez: Gide precisava escrever para viver $^{29}$. Em Gide, a escrita e a própria vida dão de cara uma com a outra, andam encostadas uma na outra. Isso pode ser lido de forma não tão obscura (já que esse é um fenômeno por si

\footnotetext{
28 "Como explicar que essa coabitação dos extremos em mim não trazia tanta inquietude e sofrimento quanto uma intensificação patética do sentimento da existência, da vida? As tendências mais opostas jamais conseguiram me tornar um ser atormentado; mas perplexo - pois o tormento acompanha um estado do qual se deseja sair, e eu não desejava de forma alguma escapar daquilo que dava vigor a todas as virtualidades do meu ser; esse estado de diálogo, que para tantos é quase intolerável, tornava-se para mim necessário". Epígrafe de Morceaux choisis.

${ }^{29}$ Goulet, A. "Gide em Pauta". In: Revista ALEA. jul-dez. 2003. p. 195.
} 
obscuro), por exemplo, na prática do Diário, que Gide jamais ousou abandonar. O Diário é o lugar em que a vida e a escrita formam um ponto de intersecção muito evidente e até mesmo didático ${ }^{30}$.

Seria possível, então, imaginar uma circunstância em que as trajetórias entre os destinos: diálogo, escrita e vida constituiriam o próprio espaço dentro do qual Gide se localiza, dentro do qual podemos vê-lo. Renata Lopes Araújo - cujo trabalho de mestrado nasce essencialmente de um desejo de fazer dois escritores, Gide e Perec, se encontrarem - ressalta o quanto é importante não considerar a figura autoral Gide dentro dos paradigmas da inspiração e do isolamento, mas sim a partir dos paradigmas da abertura e da interlocução. Ela põe em relevo, inclusive, de que forma, em Paludes, a imagem do escritor não é apresentada como uma figura mística ou um criador, mas como aquele que repete infinitamente a diferença ${ }^{31}$. Observando, ainda que muito brevemente, certos pilares em relação aos quais Gide se orientava, constroem-se janelas para a casa fechada do autor janelas ou terraços ou mesmo uma escadaria completa e depois mais andares - e o espaço se torna infinitamente mais amplo, mais convidativo e arejado.

Certos opositores de Gide, por exemplo, foram fundamentais para as suas construções:

Massis précisait bien qu'il dédaignait de faire à Gide " un procès d'immoralité, le procès fait à Baudelaire, à Wilde, à Rimbaud, par exemple. II s'agit bien de cela ! C'est le procès fait à Rousseau, c'est-à-dire à un réformateur. Gide est un réformateur, en ce que sa critique porte atteinte à I'unité de la personne humaine, à l'organisation même de l'être spirituel ». Et Gide acquiesçait, demandant même à Massis la permission de mettre en

\footnotetext{
${ }^{30}$ Claudia Amigo Pino oferece essa perspectiva no início de sua tese sobre Roland Barthes, valendo-se de uma divisão que determinaria dois caminhos possíveis para esse autor: a escrita da vida concomitante ao seu presente (calcada no diário de Gide), e a escrita a partir da morte (encontrada na escrita da História, de Michelet). In: Em busca de uma vida nova: O projeto de romance de Roland Barthes. pp. 20-41.

${ }^{31}$ Araújo, R. L. André Gide e Georges Perec: os diálogos potenciais. pp. 8-9.
} 
épigraphe d'un des chapitres des Faux-Monnayeurs, qu'il écrivait alors, la phrase capitale de son article de novembre 1923 à propos du Dostoïevsky : Ce qui est mis en cause ici, c'est la notion même de l'homme sur laquelle nous vivons. C'était bien là, et il plaisait à Gide d'être ainsi attaqué au bon endroit, découvrir la véritable dimension de la pensée gidienne. ${ }^{32}$

Para Henri Massis, crítico em atividade no momento em que Gide obteve um enorme reconhecimento como escritor (as décadas de 1910 e 1920), Gide é um reformador naquilo que sua crítica tem de afronta à unidade da pessoa humana, à organização do ser espiritual. Não se trata das críticas mais rasas e até muito constantes a respeito de sua imoralidade, motivadas pelo fato de que ele criava personagens que haviam superado em alguma medida a heteronormatividade dominante (como, por exemplo, em Si le grain ne meurt ou em Corydon). Massis teve sensibilidade para compreender que a afronta reformadora de Gide se dirigia à unidade da pessoa humana. É essa a sua mais fundamental provocação.

Para Gide, a sensibilidade crítica do opositor foi imprescindível, já que a sua defesa de uma outra maneira de lidar com o eu, de se colocar na posição de um eu, se levantou com força, com clareza, com militância somente depois dessa crítica. Ele pôde, assim, desenvolverse, ramificar-se, abrir mais portas e mais janelas no interior de si mesmo: agradava a Gide ser atacado no lugar certo, descobrir a verdadeira dimensão de seu pensamento. $\mathrm{O}$ ataque de seu opositor é acima de tudo um desvelamento de si próprio. A crítica de Massis torna-se de tal modo constitutiva, que Gide pede permissão para utilizá-la como epígrafe de seu ensaio sobre

\footnotetext{
32 "Massis deixava bem claro que se abstinha de processar Gide "por sua imoralidade, tal como havia sido com Baudelaire, com Wilde ou com Rimbaud, por exemplo. Trata-se precisamente disso! É o processo contra Rousseau, isto é, contra um reformador. Gide é um reformador pelo que sua crítica tem de afronta à unidade da pessoa humana, à própria organização do ser espiritual". E Gide concordava com isso, pedindo inclusive permissão a Massis para colocar como epígrafe de um dos capítulos de Les Faux-monnayeurs, que ele estava escrevendo naquele momento, a frase capital de seu artigo de novembro de 1923 sobre Dostoievski: o que se põe em xeque aqui é a própria noção do homem na qual vivemos apoiados. Era exatamente isso, e agradava a Gide ser atacado no lugar certo, descobrir a verdadeira dimensão do pensamento gideano". Martin, C. Gide. p. 141.
} 
Dostoievski, ensaio que também manifesta uma leitura de Dostoievski como leitura de si próprio. Esse movimento só irá cada vez mais se multiplicar ${ }^{33}$. Contudo, é importante dizer que tais trocas, por assim dizer, não se submetem ao grandioso lance de escadas das influências, mas como que constituem uma zona plana de jogo, uma planície em que as associações se transformam no próprio trampolim da escrita: l'origine de l'oeuvre, ce n'est pas la première influence, c'est la première posture ${ }^{34}$.

${ }^{33}$ Relembro algo fundamental que Barthes percebe em Gide em "Notas sobre André Gide e seu diário": "é uma obra egoísta, mesmo quando - e, sobretudo, exatamente quando - fala dos outros. Embora a marca de Gide seja sempre a grande acuidade, o seu grande valor está na força de reflexão, de retorno para o próprio Gide". Inéditos vol 2 - Crítica. p. 3.

34 “A origem da obra não é a primeira influência, é a primeira postura”. RB par RB. p. 119. 
Paisagens intermediárias 


\section{Mapa}

"Gide", texto de Georges Poulet de La pensée indeterminée, se propõe já em suas primeiras linhas a realizar uma investigação sobre o espaço em André Gide. Mas, logo que adentra essa busca, Poulet encontra, não um espaço que possa explorar, mas uma grande suspeita sobre a existência mesma de um espaço em Gide:

Il apparaît tout de suite que, chez Gide, l'espace, pris sous sa forme la plus générale et la plus nue, n'existe pas. Ou bien il se présente sous l'apparence d'une simple pluralité indéterminée de lieux. Ceux-ci, pour Gide, sont le plus souvent rigoureusement séparés les uns des autres. ${ }^{35}$

O espaço não existe, diz ele, segundo a determinação a mais geral, a mais nua, em Gide. O que é um espaço geral, nu? Poulet não o explica de modo generalizante, mas partindo do próprio texto de Gide do qual ele retira suas leituras, Les Nourritures terrestres. Nesse livro, o espaço é fundado por uma pluralidade indeterminada de lugares separados uns dos outros. Não só separados, como rigorosamente separados: trata-se de uma escansão enfática e ostensiva.

Les Nourritures terrestres (d'où, pour plus de commodité, nous tirons ici nos exemples) sont remplies par de longues énumérations de villes, de jardins, d'oasis, de sources, qui ont pour caractéristique principale de ne jamais former un ensemble de lieux liés les uns aux autres et fixés en des points précis sur une étendue les contenant tous. L'espace gidien est une pure collection de localités détachées, placées indépendamment les unes

\footnotetext{
35 "Aparece logo de cara que, em Gide, o espaço, tomado sob sua forma a mais geral e a mais nua, não existe. Ou ainda ele se apresenta sob a aparência de uma simples pluralidade indeterminada de lugares. Estes, para Gide, estão com frequência rigorosamente separados uns dos outros". Poulet, G. "Gide ", In : La pensée indeterminée. p. 232.
} 
des autres dans la pensée, comme une certaine quantité de portraits de personnes diverses, contenus dans le même album. ${ }^{36}$

Para Poulet, há uma abundância de cidades, jardins, oásis, colocados em longas enumerações em Les Nourritures terrestres que, no entanto, não se articulam num todo que seja vinculado e referenciado por pontos precisos, numa região que os contenha todos. Em outras palavras, seria impossível fazer com que as localidades de Les Nourritures terrestres se organizassem num grande ponto de encontro. Elas estão simplesmente dispersas, não se vinculam nem se tocam, só operam de forma introspectiva nas suas esferas particulares, nos seus mundos próprios. É por isso que a sua forma textual é a enumeração. Não se trata de frases com verbos que liguem essas localidades, frases nas quais elas ocupem a posição de complementos. Elas simplesmente emergem, desvinculadas de todo o resto, como nesse excerto:

Naples; petite boutique du coiffeur devant la mer et le soleil. Quais de chaleur ; stores qu'on soulève pour entrer. On s'abandonne. Est-ce que cela va durer longtemps ? Quiétude. Gouttes de sueur aux tempes. Frisson de la mousse de savon sur les joues. ${ }^{37}$

Num livro que reúne uma coletânea de obras de artes plásticas cujo tema é a cartografia, a curadora e pesquisadora Katharine Harmon diz que mapas ... carregam

\footnotetext{
36 “Les Nourritures terrestres (de onde, por comodidade, nós tiramos aqui nossos exemplos) são preenchidas por longas enumerações de cidades, de jardins, de oásis, de fontes, que têm por característica principal não formar jamais um conjunto de lugares ligados uns aos outros e fixos em pontos precisos numa extensão que os contenha todos. $O$ espaço gideano é uma pura coleção de localidades destacadas, posicionadas independentemente umas das outras no pensamento, como uma certa quantidade de retratos de pessoas diversas, contidos num mesmo álbum". Ibid. p. 233.

37 "Nápoles; pequeno estabelecimento do cabeleireiro diante do mar e do sol. Docas de calor; cortinas que erguemos para entrar. Abandonamo-nos. Será que vai durar muito tempo? Quietude. Gotas de suor nas têmporas. Atrito da espuma do sabão nas bochechas". Les Nourritures terrestres. p. 51.
} 
promessas implícitas de rotas para o desconhecido ${ }^{38}$, e, mais tarde, que mapas convencionais não podem fazer mais do que apontar o caminho para a experiência individual, imprevisível³. Essa circunscrição do papel do mapa convencional é uma oposição que a autora estabelece entre a cartografia tradicional e artistas plásticos que incorporam a promessa de experiência contida nos mapas, levando essa experiência adiante, desdobrando-a cada um à sua maneira. Penso que a função que Poulet atribui ao espaço em Gide é bastante semelhante à promessa de experiência contida num mapa convencional:

Tout se passe comme si chez Gide les lieux, de même que les temps, et finalement les expériences humaines, étaient toujours incomparables les uns aux autres et offraient chacun une valeur absolue. En quelque endroit que l'être gidien se découvre ou s'imagine, le voilà prêt à goûter en cet endroit le maximum de contentement qu'il comporte, à en jouir comme si c'était là le seul bonheur qu'il y eût au monde et le seul lieu. ${ }^{40}$

Os espaços só importam à medida que o être gidien, na fórmula de Poulet, se veja prestes a encontrar neles algum tipo de sedução, de contentamento. Prestes a: essas experiências não são relatadas ou desenvolvidas, elas apenas assomam sob a forma incipiente de expectativas - como um mapa não é o próprio lugar, mas a sua promessa.

Retornando à pergunta que formulei antes, aquela configuração espacial mais geral e mais nua - que não está em Gide, e que Poulet evoca a título de oposição - seria, então, um todo coordenado, que contém em si uma multiplicidade obediente, ligada pela narração (pelos trajetos das personagens, por exemplo). De fato, em Les Nourritures terrestres não há

\footnotetext{
38 "Maps ... bear implicit promises of routes into and out of the unknown". Harmon, K. "Introduction". In: The Map as Art. p. 9.

39 "Conventional maps can do no more than point the way to unpredictable, individual experience". Ibid. p. 15.

40 "Tudo se passa como se em Gide os lugares, assim como os tempos, e finalmente as experiências humanas, fossem sempre incomparáveis uns aos outros e oferecessem cada um um valor absoluto. Em qualquer lugar que o ser gideano se descubra ou se imagine, ei-lo prestes a provar nesse lugar o máximo de contentamento que ele comporta, a gozar disso como se fosse o único prazer que existisse no mundo e o único espaço". Poulet, G. Op. Cit. p. 235.
} 
nenhum impulso narrativo que desbrave trajetos nos espaços que são incansavelmente enumerados. Eles são simplesmente nomeações, florestas intactas, desprovidas de verbos que os associem, como as trilhas associam pontos divergentes no espaço (ando de uma casa até o alto de uma pedra, dirijo numa rodovia durante a noite, do meu apartamento até uma casa na praia). O que conta é a sua numerosa existência desarticulada, e não os eventos que se desdobrariam naqueles lugares - e que, por sua vez, engendrariam novos eventos em lugares que se vinculariam aos anteriores.

Poulet ainda diz que os lugares em Gide são enumerados a partir dos caprichos da associação de ideias ${ }^{41}$, numa evocação não coordenada ${ }^{42}$. O espaço gideano é uma pura coleção de localidades destacadas, posicionadas independentemente umas das outras no pensamento, como uma certa quantidade de retratos de pessoas diversas, contidos num mesmo álbum. A imagem do álbum me traz à memória uma outra evocação de álbum, que não é de todo estranha à primeira - e que pode inclusive iluminá-la. Refiro-me a um texto de Roland Barthes intitulado "Déliberation", cujo tema central é a escrita de um diário. Em determinado momento, Barthes dirige-se aos Diários de Gide:

Les œuvres de la littérature, de Dante à Mallarmé, à Proust, à Sartre, ont toujours eu, pour ceux qui les ont écrites, une sorte de fin, sociale, théologique, mythique, esthétique, morale, etc. Le livre, " architectural et prémédité ", est censé reproduire un ordre du monde, il implique toujours, me semble-t-il, une philosophie moniste. Le Journal ne peut atteindre au Livre (à l'CEuvre) ; il n'est qu'Album, pour reprendre la distinction mallarméenne (c'est la vie de Gide qui est une "œuvre ", ce n'est pas son Journal). L'Album est collection de feuillets non seulement permutables (ceci encore ne serait rien), mais surtout suppressibles à l'infini : relisant mon

\footnotetext{
${ }^{41}$ Em francês : les caprices de l'association des idées. Ibid. p. 233.

42 « Évocation non coordonnée ». Ibid. p. 234.
} 
journal, je puis barrer une note après l'autre, jusqu'à l'anéantissement complet de l'Album, sous prétexte que " cela ne me plaît pas ".$^{43}$

O álbum de Barthes evoca o mesmo tipo de oposição que a imagem do álbum em Poulet. Em Barthes, o álbum surge numa contraposição emprestada de Mallarmé entre Álbum e Livro. O Livro seria algo que se realiza a partir de um plano da obra, que é arquitetural, além de representar alguma coisa ao mesmo tempo em que a ordena, depreendendo de toda aquela trajetória uma espécie de objetivo, de término (que Barthes exemplifica na enumeração de finalidades sociais, teológicas, míticas, estéticas, morais). Já o álbum não parte desse mesmo pressuposto. O álbum é uma mera coleção de folhas permutáveis e suprimíveis. Lembro-me do grande romance proustiano que se constrói sempre a partir da adição: Proust colava páginas no meio do manuscrito já revisto pelo editor da Recherche du temps perdu, de modo que o seu livro fosse uma constante expansão de dentro para fora (expansão que durou toda a sua vida). Já a lógica do álbum é a supressão, administrada por uma arbitrariedade pessoal operante na escrita do diário: não gosto disso, vou rasgar aquilo outro. Essa supressão lança luz ao caráter permutável das partes de um álbum, que talvez nem sejam partes, uma vez que isso pressuporia um todo ao qual elas se integrassem. Barthes não torna a existência do todo um ponto de reflexão em si, mas ainda assim posso me perguntar se o álbum pressupõe realmente a totalidade, assim como Poulet se questiona sobre a existência de um todo que agrupe a desigualdade dos lugares em Gide. Os trajetos, os vínculos se esgotam

\footnotetext{
43 As obras da literatura, de Dante a Mallarmé, a Proust, a Sartre, sempre tiveram, para aqueles que as escreveram, uma espécie de fim, social, teológico, mítico, estético, moral, etc. O livro "arquitetônico e premeditado", é visto como reproduzindo uma ordem do mundo, ele implica sempre, parece-me, uma filosofia monista. O Diário não pode atingir o Livro (a Obra); é apenas um Álbum, para retomar a distinção mallarmeana (a vida de Gide é que é uma "obra”, não o seu Diário). O Álbum é coleção de folhas não apenas permutáveis (isso ainda não seria nada), mas principalmente suprimíveis ao infinito: relendo o meu Diário, posso cancelar uma anotação depois da outra, até o aniquilamento completo do Álbum, sob o pretexto de que "não me agrada". Barthes, R. « Délibération ». p. 678-9 para o original e “Deliberação”. p. 369-70, Trad. Mario Laranjeira.
} 
assim que se ultrapassa a circunscrição dos lugares em sua particularidade. Isso, inclusive, é dito no próprio Les Nourritures terrestres:

Les sources seront où les feront couler nos désirs ; car le pays n'existe qu'à mesure que le forme notre approche, et le paysage à l'entour, peu à peu, devant notre marche se dispose ; et nous ne voyons pas au bout de l'horizon; et même près de nous ce n'est qu'une successive et modifiable apparence. $^{44}$

44 "As fontes estarão onde as farão correr nossos desejos; pois o país só existe à medida que o forma nossa aproximação, e a paisagem ao redor, pouco a pouco, diante de nossa caminhada se dispõe; e nós não enxergamos o término do horizonte; e mesmo perto de nós não se trata senão de uma sucessiva e mutável aparência." Les Nourritures terrestres. p. 20. 


\section{O espaço que somos}

Gostaria ainda de retomar muito brevemente, nessas paisagens intermediárias, um artigo de Émile Benveniste intitulado "De la subjectivité dans le langage", fundamental para o que direi mais tarde. Esse texto se concentra na seguinte pergunta: o que é um eu? o je é, primeiramente, um ensinamento da língua: é a língua que ensina a definição do homem ${ }^{45}$, e não o contrário. Benveniste o enuncia num texto dedicado ao tema da subjetividade na linguagem. Mas, para além de uma paráfrase das ideias de Benveniste (que de resto são colocadas de forma clara pelo autor), me interessa pensar a terminologia por ele empregada ao longo desse artigo, quando ele fala precisamente do sujeito:

La « subjectivité » dont nous traitons ici est la capacité du locuteur à se poser comme « sujet ${ }^{46}$

Le discours provoque l'émergence de la subjectivité. ${ }^{47}$

L'instance de discours est ainsi constitutive de toutes les coordonnées qui définissent le sujet. ${ }^{48}$

L'installation de la " subjectivité " dans le langage crée, dans le langage et, croyons-nous, hors du langage aussi bien, la catégorie de la personne. ${ }^{49}$

\footnotetext{
45 " C'est un homme parlant que nous trouvons dans le monde, un homme parlant à un autre homme, et le langage enseigne la définition même de l'homme ". " De la subjectivité dans le langage ", In:PLG I. p. 259.

46 "A "subjetividade" de que falamos aqui é a capacidade do locutor de se colocar como "sujeito"." Ibid. p. 259.

Os grifos em negrito são meus.

47 "O discurso provoca a emergência da subjetividade". Ibid. p. 263.

48 "A instância de discurso é assim constitutiva de todas as coordenadas que definem o sujeito". Ibidem.

49 "A instalação da "subjetividade" na linguagem cria, na linguagem e, acreditemos, também fora dela, a categoria da pessoa". Ibidem.
} 
La forme personnelle est, si l'on peut dire, l'indicateur de subjectivité. ${ }^{50}$

Diz Benveniste: a "subjetividade" da qual falamos aqui é a capacidade do locutor de se colocar como "sujeito". Primeiramente, me chama a atenção a palavra subjetividade entre aspas, que produz, a meu ver, um distanciamento em relação à naturalidade com a qual o termo pode ser empregado. Após esse primeiro distanciamento, que coloca num andaime os pressupostos $^{51}$ de uma subjetividade sem aspas, Benveniste diz, de modo simples e direto, que a subjetividade é a capacidade do locutor de se colocar. Já não se trata, de saída, de se exprimir, como é comum pensar, levando em conta um certo raciocínio das relações entre sujeito e língua. Segundo essa lógica, quando um locutor diz je, ele simplesmente transforma em palavras a sua subjetividade previamente existente e consolidada. Mas não para Benveniste. Em francês o verbo empregado (se poser) se aproxima do equivalente se posicionar em português, que talvez seja ainda mais adequado nesse caso. $\mathrm{O}$ sujeito é, antes de tudo, um posicionamento: ser sujeito é ocupar um lugar em algum tipo de espaço. Descontextualizados, esse espaço nos aparece como um enigma, mas retornando ao título do artigo, tomamos conhecimento de que ele se refere ao espaço da língua: "De la subjectivité dans le langage". Não se trata, assim, de uma relação sequencial de anterioridade (substância sujeito) / posteridade (expressão linguística), mas de uma sincronia espacial, em que sujeito e língua se oferecem de uma só vez.

\footnotetext{
50 “A forma pessoal é, se podemos dizer assim, o indicador de subjetividade". Ibid. p. 264.

51 No que concerne a esses pressupostos, Benveniste menciona, por exemplo, uma substância psíquica que frequentemente se torna uma espécie de referência objetiva do pronome je. Algo como uma massa amorfa, um estado de pré-linguagem que definiria o nosso eu.
} 
Atentemos ainda para a segunda citação, que traz à tona a ideia de um movimento: $o$ discurso provoca a emergência da subjetividade. A subjetividade emerge, como um mergulhador emerge do fundo da água. O movimento de emergir é um acontecimento na água, que pressupõe, dessa forma, um espaço em que ele possa ocorrer: a subjetividade emerge dentro de um espaço mais vasto, que é a linguagem. Emergir é tornar-se relevante dentro de um estabelecimento prévio, tal como a uniformidade da água antes do mergulhador dela emergir. Além desse verbo, para Benveniste, a subjetividade também se instala: ela é como o novo morador de uma casa, ou como o novo parasita de um organismo. De resto, coordenadas e indicadores: todos termos correspondentes à localização num mapa, que convocam a ideia de posicionamento. Ser sujeito é ocupar uma posição que seja indicadora dessa coordenada sujeito: como se, dizendo je, eu me transformasse num mapa em que meu interlocutor tu pudesse me ver e me encontrar. 
Regiões: Cordilheiras 


\section{Neve que bloqueia as rotas}

Em La Symphonie pastorale, um pastor se aproveita de uma excepcional retenção em casa por causa da neve, que fecha as estradas e o impede de cumprir seus trajetos costumeiros, para narrar sua própria história:

La neige, qui n'a pas cessé de tomber depuis trois jours, bloque les routes. Je n'ai pu me rendre à R... où j'ai coutume depuis quinze ans de célébrer le culte deux fois par mois. Ce matin trente fidèles seulement se sont rassemblés dans la chapelle de La Brévine.

Je profiterai des loisirs que me vaut cette claustration forcée, pour revenir en arrière et raconter comment je fus amené à m'occuper de Gertrude. $^{52}$

A tempestade de neve que impede a sua saída instaura um tédio generalizado por toda a comuna (essa manhã, somente trinta fiéis se reuniram na capela). A atmosfera que toma a população é de apatia e recolhimento: todos se retiram em suas próprias casas, e o pastor, sem escolha, é ele mesmo levado a um claustro forçado. Sob a influência dessa reclusão solitária, em que o tempo se prolonga uniforme, anestesiado, o pastor resolve construir a sua narração. Não é de se estranhar: quando somos invadidos pelo tédio, subjugados a uma monotonia de cenário, as fugas, as visitas imaginárias se multiplicam: lugares a céu aberto e viagens mentais, cenas e o passado que reaparece de modo exaustivo.

O encadeamento dos parágrafos potencializa uma tendência associativa presente nessa história que será contada: aproveitarei do tempo livre que me oferece essa clausura

\footnotetext{
52 “A neve, que não parou de cair já faz três dias, bloqueia as estradas. Não pude ir à R... onde tenho o costume há quinze anos de celebrar o culto duas vezes por mês. Essa manhã trinta fiéis somente se reuniram na capela de La Brévine. / Aproveitarei o tempo livre que me oferece esse claustro forçado para me voltar ao passado e contar como fui levado a me ocupar de Gertrude." La Symphonie pastorale. p. 11.
} 
forçada, para voltar ao passado e contar como fui levado a me ocupar de Gertrude. Ainda que o ato de narrar seja esclarecido pela sobra de tempo livre, nada sobrevém como justificativa de por que a história contada será justamente a de Gertrude, e não qualquer outra. Entre o isolamento causado pela neve e Gertrude há uma associação de ideias imediata e nebulosa. Além disso, nesse mesmo trecho, o pastor prepara o terreno para sua história como se um espaço precisasse ter sido aberto para que a confidência pudesse tomar lugar. Para ele, o gesto de contar aquela história exige um hiato no desenrolar cotidiano da vida - tal como as revelações que só acontecem por pessoas embriagadas, de noite - que abrigue a narrativa de como ele foi levado a se ocupar de Gertrude. Esse espaço singular, oportuno para a confidência, é uma ilha fora do hábito: o pastor está enclausurado pela neve, não pode ir à R... e é aí que decide escrever. A escrita é a figuração dessa clausura e também dessa exceção. Acompanhemos o início da história anunciada:

Il y a deux ans et six mois, comme je remontais de La Chaux-deFonds, une fillette que je ne connaissais point vint me chercher en toute hâte pour m'emmener à sept kilomètres de là auprès d'une pauvre vieille qui se mourait. Le cheval n'était pas dételé ; je fis monter l'enfant dans la voiture, après m'être muni d'une lanterne, car je pensai ne pas pouvoir être de retour avant la nuit.

Je croyais connaître admirablement tous les entours de la commune ; mais passé la ferme de la Saudraie, l'enfant me fit prendre une route où jusqu'alors je ne m'étais jamais aventuré. ${ }^{53}$

O início daquilo que, futuramente, culminará no encontro com Gertrude é desencadeado a partir de uma sinuosidade em relação ao percurso habitual do pastor:

\footnotetext{
53 “Há dois anos e seis meses, quando eu voltava de La Chaux-de-Fonds, uma mocinha que eu não conhecia veio me procurar apressadamente para me levar a sete quilômetros dali, para uma pobre velha que estava morrendo. O cavalo não estava desatrelado; eu fiz a jovem subir na carroça, depois de ter me munido de uma lanterna, pois imaginei não poder retornar antes do anoitecer. / Eu acreditava conhecer admiravelmente todos os arredores da comuna; mas, passada a fazenda de la Saudraie, a jovem me fez tomar uma estrada pela qual até então eu nunca havia me aventurado." Ibid. p. 12.
} 
repentinamente, a sua presença é convocada para acompanhar o falecimento de uma senhora, numa cidade vizinha, cujo trajeto será atravessado junto da jovem que acaba de abordá-lo. O imprevisto dessa situação é duplicado na concretude do itinerário percorrido, que significa, ele também, uma novidade digna de nota para o pastor: eu acreditava conhecer admiravelmente todos os arredores da comuna; mas, passada a fazenda de la Saudraie, a jovem me fez tomar uma estrada pela qual até então eu não havia nunca me aventurado. 0 encontro com a jovem levanta uma ressalva dentro do espaço presumido - ressalva simétrica à excepcionalidade da clausura pela neve, que produziu a escrita.

Assim, a jovem, acompanhando o pastor até a residência da velha enferma, desorganiza uma noção de espaço anterior, levando-o por um novo trajeto. Aliás, é curioso como a oração é introduzida pelo verbo croire: eu acreditava conhecer admiravelmente todos os arredores da comuna. Ou seja, o que a jovem desestrutura é precisamente uma crença, inserindo - não necessariamente para a figura do pastor, mas de uma forma mais ampla, de sobrevoo - uma desconfiança na narrativa. É claro que isso não é nada demais; trata-se apenas de uma crença num suposto domínio dos espaços. Não deixa, contudo, de ser a crença de um pastor. Edifica-se aí uma espécie de aglomeração de sentidos que se enfileiram num recinto apertado, introdutório, para a organização de uma cena preliminar. O núcleo da trama é como que anunciado por pequenos indícios que vão se acumulando desde o início. Dessa forma, previamente a qualquer rompimento de hábitos - que ocorrerá efetivamente no encontro com Gertrude -, as frases do pastor se abrem à propagação de uma suspeita enigmática, como um eco ouvido antes da voz que lhe deu origem.

O que me interessa acima de tudo é observar o valor estruturante da exceção. Ela é um eixo em torno do qual toda a narrativa se levanta. No último excerto que comentei, essa exceção é introduzida por um mas, que é, linguisticamente, a concentração numa só partícula 
de um acúmulo de excepcionalidade: eu acreditava conhecer admiravelmente todos os arredores da comuna; mas, passada a fazenda de la Saudraie, a jovem me fez tomar uma estrada pela qual até então eu nunca havia me aventurado. Conservemos essa informação.

Na casa em que o pastor realiza a extrema unção, ele conhece Gertrude, sobrinha da mulher que estava prestes a falecer. Através da jovem que o acompanhou, ele fica sabendo que Gertrude tem algum problema interacional (a jovem insinua que ela é doente mental) e, compadecido, segundo suas próprias palavras, o pastor decide levá-la consigo até a sua casa. Ao chegarem, no entanto, ele e Gertrude são recebidos com muita hostilidade por sua esposa Amélie e por seus filhos. Mais tarde, o pastor tem uma discussão com Amélie a respeito da situação:

Aux premières phrases de sa sortie, quelques paroles du Christ me remontèrent du cœur aux lèvres, que je retins pourtant, car il me paraît toujours malséant d'abriter ma conduite derrière l'autorité du livre saint. Mais dès qu'elle argua de sa fatigue je demeurai penaud, car je reconnais qu'il m'est arrivé plus d'une fois de laisser peser sur ma femme les conséquences de mon zèle. Cependant ces récriminations m'avaient instruit sur mon devoir ; je suppliai donc très doucement Amélie d'examiner si à ma place elle n'eût pas agi de même et s'il lui eût été possible de laisser dans la détresse un être qui manifestement n'avait plus sur qui s'appuyer. ${ }^{54}$

A forma pela qual a discussão se organiza na voz do pastor é bastante singular, o que pode ser observado desde a primeira frase: logo de cara, ele revela que os argumentos subiram à sua boca, no entanto, naquele momento, ele os reteve todos, temeroso de ocultarse sob o discurso bíblico (toda essa narrativa, aliás, é uma oscilação entre colar-se à moral

\footnotetext{
54 “Nas primeiras frases de sua investida, algumas palavras de Cristo me subiram do coração aos lábios, que eu retive no entanto, pois parece-me sempre inadequado abrigar minha conduta sob a autoridade do livro santo. Mas desde que ela argumentara sobre o seu cansaço fiquei constrangido, pois reconheço que me aconteceu mais de uma vez deixar pesar sobre minha mulher as consequências de meu zelo. Contudo essas recriminações me haviam instruído sobre meu dever; eu suplicava então muito delicadamente que Amélie examinasse se em meu lugar ela não teria agido da mesma maneira e se lhe teria sido possível largar no sofrimento um ser que evidentemente não tinha mais ninguém em quem pudesse se apoiar." Ibid. pp. 23-4.
} 
protestante, a partir do livro santo, e distanciar-se dela, produzindo alguma outra coisa). A seguir, há uma nova contradição entre ideias introduzida pelo mas, indicando que - embora se opusesse a Amélie, por mais que tivesse silenciado a sua opinião -, a partir do momento em que ela assume estar exausta pelo serviço doméstico e pelos outros filhos, o pastor, tomado por um sentimento de culpa, admite que ela está certa. Essa minha paráfrase longa e até um pouco confusa ressoa o raciocínio intrincado, na forma pela qual ele é apresentado no excerto. Logo a seguir, lemos:

Contudo essas recriminações me haviam instruído sobre meu dever; eu suplicava então muito delicadamente que Amélie examinasse se em meu lugar ela não teria agido da mesma maneira e se lhe teria sido possível largar no sofrimento um ser que evidentemente não tinha mais ninguém em quem pudesse se apoiar.

A continuação do relato não estabelece uma posição firme de acordo com a esposa (por ela já estar exausta, já ter de cuidar dos outros filhos, etc.); pelo contrário, a conclusão do raciocínio é apenas uma teimosia, que direciona o pastor de volta à sua inclinação inicial de tomar conta de Gertrude. Ou seja, de uma só vez, ele concorda e discorda de Amélie. Ou, ainda, só pode relatar a sua discordância através de potenciais harmonias em relação à esposa (potenciais pois elas não chegam a fundamentar em verdade a sua decisão): ela tem razão, ela está exausta, todo o trabalho da família e da casa recai sobre seus ombros, compreendo tudo isso, mas quero abrigar Gertrude mesmo assim. A argumentação se dá de forma irregular, com muitas voltas.

E o desejo de manter Gertrude sob o mesmo teto não cessa de dar lugar a explicações:

Il ne me vint pas aussitôt à l'esprit de prendre soin moi-même de cette pauvre abandonnée ; mais après que j'eus prié - ou plus exactement pendant la prière que je fis, entre la voisine et la petite servante, toutes deux 
agenouillées au chevet du lit, agenouillé moi-même, - il m'apparut soudain que Dieu plaçait sur ma route une sorte d'obligation et que je ne pouvais pas sans quelque lâcheté m’y soustraire. ${ }^{55}$

A obrigação de cuidar de Gertrude é algo milagroso, que surge de forma repentina: apareceu-me subitamente que Deus colocava sobre meu caminho uma espécie de obrigação e que eu não poderia sem alguma covardia dela me subtrair. Justificar um tal sentimento de incumbência em relação a Gertrude com o emprego do verbo aparecer, na impessoalidade da $3^{\text {a }}$ pessoa ${ }^{56}$, é opor-se a um possível comprometimento de seu gesto com o que havia ocorrido anteriormente. O que aparece simplesmente aparece, é algo repentino, desmotivado. Ao mesmo tempo, o discurso do pastor nesse parágrafo funciona como uma exposição das condições através das quais ele tomou sua decisão de se tornar preceptor de Gertrude. Há uma tendência à retratação, uma busca pelo compadecimento alheio. Mas como explicar aquilo que é infundado? Quando o pastor emprega o verbo aparecer, ele se justifica esvaziando toda e qualquer justificativa: a causalidade divina pode ser lida também como um ato gratuito ${ }^{57}$. Isso porque, se as frases construíssem uma real fundamentação de seu gesto,

\footnotetext{
55 “Não me veio imediatamente à cabeça tomar conta eu mesmo dessa pobre abandonada; mas depois de ter rezado - ou mais exatamente, durante a oração que fiz, entre a vizinha e a jovem criada, ambas ajoelhadas na beira da cama, ajoelhado eu mesmo, - apareceu-me subitamente que Deus colocava sobre meu caminho uma espécie de obrigação e que eu não poderia sem alguma covardia dela me subtrair." Ibid. p. 21.

${ }^{56} \mathrm{O}$ uso do termo impessoalidade me é sugerido pelo seguinte excerto de Émile Benveniste: "La forme dite de $3^{e}$ personne comporte bien une indication d'énoncé sur quelqu'un ou quelque chose, mais non rapporté à une " personne " spécifique. L'élément variable et proprement " personnel » de ces dénominations fait ici défaut. C'est bien I' " absent " des grammairiens arabes. II ne présente que l'invariant inhérent à toute forme d'une conjugaison. La conséquence doit être formulée nettement : la " $3^{e}$ personne » n'est pas une " personne »; $c^{\prime}$ est même la forme verbale qui a pour fonction d'exprimer la non-personne." "A forma dita de 3 a pessoa comporta uma indicação de enunciado sobre alguém ou alguma coisa, mas ela não está vinculada a uma "pessoa" específica. O elemento variável e propriamente "pessoal" dessas denominações falta aqui. É exatamente o "ausente" dos gramáticos árabes. Ele apenas apresenta aquela invariável inerente a toda forma de uma conjugação. A consequência deve ser formulada claramente: a "3a pessoa" não é uma "pessoa"; é inclusive a forma verbal que tem por função exprimir a não pessoa." "Structure des relations de personne dans le verbe ", In : PLG I. p. 228.

${ }^{57} \mathrm{O}$ que adquire ainda mais sentido se pensado numa relação mais ampla com a obra de Gide, que foi muitas vezes lida como uma reiteração insistente do ato gratuito. Isso está, por exemplo, no texto de Roger Bastide em Anatomie d'André Gide, no capítulo intitulado "Masque, fête et nudité", ou em "Notas sobre André Gide e seu Diário" de Barthes, no fragmento a respeito da gratuidade de Les Faux-Monnayeurs, que, segundo Barthes, é
} 
Gertrude teria sido recusada, depois das sucessivas investidas de Amélie contra a sua estadia. O súbito interesse do pastor em levar a jovem consigo só pode, em tais condições, ser argumentado do ponto de vista de uma intervenção divina: é uma vez mais um estado de exceção, que só faz sentido levando em conta que tudo nos é relatado através das palavras de um homem religioso, numa circunstância muito peculiar.

Essa particularidade aflora na coordenação das orações: não me veio imediatamente à cabeça tomar conta eu mesmo dessa pobre abandonada; mas depois de ter rezado-ou mais exatamente, durante a oração que fiz, entre a vizinha e a jovem criada, ambas ajoelhadas na beira da cama, ajoelhado eu mesmo, - apareceu-me subitamente (...) Subsistem, de forma a protelar a aparição, inúmeras ressalvas e pontuações: o mas, de mas depois de ter rezado, o traço, que impõe uma pausa na oração anterior, e ainda a expressão ou mais exatamente, que vem retificar e precisar a ideia manifesta logo antes. Isso tudo é ainda seguido pela descrição minuciosa do posicionamento do pastor durante a oração, como se a cena visual, junto da especificidade da sintaxe, construíssem um todo com vistas a um efeito persuasivo.

As frases do pastor parecem ter de construir-se de maneira irremediavelmente singular, necessitando de longas e pausadas explicações: as inúmeras justificativas de que ele se vale, as ressalvas dentro de ressalvas são um enorme funil para onde escorregam todas as palavras. Isso se relaciona com o fato evidente de, subjacente ao relato, encontrar-se um indecoroso desvio de normas requeridas para a vida exemplar de um pastor: a paixão

menos o relato de uma história do que um jogo, que se vale de elementos associados à estrutura de um romance. In: Inéditos, Vol. 2, Crítica. p. 17. 
extraconjugal por Gertrude ${ }^{58}$. Dessa forma, quando ele torna pública a sua sórdida confissão através da palavra escrita, é previsível que ele se sirva de um filtro que suavize o escândalo (o excesso de justificativas, as ressalvas, a complexidade de suas opiniões, sempre contrabalançadas por partículas de oposição $\left.{ }^{59}\right)$. Mas esse filtro é tão eficaz, cada fato se torna tão relativizado nessa narrativa, que La Symphonie pastorale se anuncia um livro muito mais provocativo do que verdadeiramente é (ao menos para os meus olhos de leitora em 2015). De todo modo, essa leitura não é o centro de meu interesse; desejo menos avançar rumo às origens ou verdades misteriosas escondidas nas formas das quais o pastor se vale do que diminuir o passo da leitura, precisamente, nessas formas.

As orações que precedem as conjunções opositivas, de modo geral, funcionam como uma fundação, um assentamento. Penso, por exemplo, na cena em que o pastor deixa Gertrude tocando piano sozinha na igreja, mas retorna antes da hora marcada apenas para poder espiá-la: /l n'est point dans mon naturel d'épier, mais tout ce qui touche à Gertrude me tient au cœur ${ }^{60}$. Não é de minha natureza espiar, diz ele. Sobressai antes de tudo a prudência em enunciar a natureza que, até ali, governou a sua vida. Já no instante seguinte, porém, esse esforço edificante, esse estrado do discurso se quebra, pela inserção do mas: não é de minha

\footnotetext{
${ }^{58}$ Alain Goulet descreve esse livro como "a sátira de um pastor moedeiro falso" ("la satire d'un pasteur fauxmonnayeur"). In: Lire Les Faux-Monnayeurs de Gide. p. 11. O pastor é, para Goulet, um grande impostor.

${ }^{59}$ Esse extremo cuidado com o que é dito e escondido é, aliás, algo recorrente em Gide, sobretudo no Journal. Em entrevista a respeito da nova edição do Journal, a pesquisadora Martine Sagaert diz que "Gide pratique l'autocensure. Les suppressions sont liées au contexte. Elles concernent l'emploi du temps personnel (les changements de résidence), les proches et les amis (sans doute pour des raisons de sécurité), mais surtout certains commentaires sur Hitler et Pétain. Telle notation "à chaud", dans un contexte si trouble, où il est si difficile d'avoir une opinion juste, a sa raison d'être sous sa forme manuscrite. Une fois imprimée, elle risque de fossiliser la réflexion en cours, de trahir son auteur." "Gide pratica a autocensura. As supressões estão ligadas ao contexto. Elas concernem ao emprego do tempo pessoal (as mudanças de residência), aos conhecidos e amigos (talvez por razões de segurança), mas sobretudo a certos comentários sobre Hitler ou Pétain. Uma tal notação feita "no calor da hora", num contexto tão turbulento, em que é tão difícil ter uma opinião precisa, tem sua razão de ser na sua forma manuscrita. Uma vez impressa, ela corre o risco de fossilizar a reflexão em curso, de trair o seu autor". "Martine Sagaert - Les manuscrits du Journal d'André Gide. Entretien avec Catherine Viollet", In: Revue Genesis, №. 32. p. 135.

60 "Não é de minha natureza espiar, mas tudo aquilo que concerne a Gertrude me toca o coração" La Symphonie pastorale. p. 70.
} 
natureza espiar, mas tudo aquilo que se refere a Gertrude toca meu coração. O estabelecimento da natureza só é introduzido para poder ser negado; isso significa que, desde a raiz, temos acesso a uma disposição de frases cujo eixo é a própria tensão. É por isso que, num dos excertos iniciais, pedi que memorizássemos a oração eu acreditava conhecer admiravelmente todos os arredores da comuna; mas, passada a fazenda de la Saudraie, a jovem me fez tomar uma estrada pela qual até então eu nunca havia me aventurado, organizada por um mas. As aparições desse conector em La Symphonie pastorale são regulares, insistentes.

Retornemos ao trecho em que o pastor observa Gertrude ao piano. Ao mesmo tempo em que prevalece nessa cena uma espécie de força contraditória que rege a coordenação das orações, o gesto de espiar é explicado por meio de um impulso do coração direcionado a Gertrude. Isto é, o fato de Gertrude ser tão cara ao pastor, de tocar tão diretamente o seu coração, acaba por funcionar, junto da determinação de seu instinto de discrição (não é de minha natureza espiar), como um apaziguamento da inconveniência em observá-la escondido. O desvio do seu comportamento natural é soterrado por uma outra natureza, que é a natureza proeminente dos seres que despertam o seu afeto. Essa natureza mais imediata é de tal forma suprema que oprime todos os seus esforços em nadar de volta para a terra firme. Assim, a sua deliberação em espiar acaba sendo destituída de qualquer carga deliberativa, tornando-se simplesmente um instinto ${ }^{61}$, que vem reforçar, uma vez mais, a propensão imaculada desse gesto.

Portanto, as orações, além de trazerem no seu cerne uma força contraditória, estão carregadas de uma certa propensão à inocência. Isto é, o pastor conta a sua história já

\footnotetext{
61 Aliás, não é novidade o peso que o argumento do instinto costuma ter sobre uma ação que pode ser recriminada.
} 
desbravando à nossa frente um caminho de interpretação dentro da floresta dos acontecimentos. Ao final da frase, o julgamento, que poderia ser uma das competências da leitura, foi feito em nosso lugar, como uma textura, um alto-relevo das palavras. Junto do ponto final reencontramos o pastor pronto para receber o perdão, o que significa que contar a sua história é também apoderar-se de tudo aquilo que dela poderá ser inferido.

Narrar é aqui manter-se vigilante e sob controle. Esse é um aspecto tão proeminente em Gide que Philippe Lejeune, numa leitura das autobiografias ${ }^{62}$, afirma que toda leitura de Gide está predestinada a ser uma mera recomposição do caminho planejado pelo próprio escritor: Gide pôde prever tudo, e qualquer interpretação de seus textos virá sempre com certo retardamento em relação a seu próprio projeto. Embora eu particularmente ache que a afirmação pressuponha uma espécie de destino do leitor demasiadamente restrito, e também o domínio de uma intencionalidade demasiadamente hipotética, há algo de reconhecível nesse autocontrole que Gide forja ter do produto de sua escrita. Trata-se de um grande esforço administrativo, um controle extremo e preparatório de tudo aquilo que é dito, que, no caso de La Symphonie pastorale sobretudo, não deixa de ser um controle do caos: aquele que enuncia é um sujeito contraditório, irregular, excepcional, reunido por conjunções de oposição. Os no entanto, mas, traços, as expressões destinadas à especificação do que se fala são aglomerações de formas curvilíneas e angulares, vales, irregularidades, acidentes sobre o solo. Mas o esforço administrativo lança luz ao fato, precisamente, de que esses inúmeros acidentes sobre o solo pressupõem ainda uma unidade, uma contenção do caótico e do contraditório numa espécie de ponto de encontro, que é, precisamente, o espaço instituído

\footnotetext{
62 Lejeune, P. "Gide et l'espace autobiographique", In: Le pacte autobiographique. O que retomei aqui se encontra sobretudo nas páginas 194-6.
} 
pelo je do pastor: um espaço complexo e poderosamente arquitetado, ao qual respeitam todos os verbos e predicados escritos nas páginas de La Symphonie pastorale. 


\section{A porta estreita}

Entremos agora por uma pequena porta cujo limiar, assim que cruzado, dá para as seguintes linhas introdutórias:

D'autres en auraient pu faire un livre; mais l'histoire que je raconte ici, j'ai mis toute ma force à la vivre et ma vertu s'y est usée. J'écrirai donc très simplement mes souvenirs, et s'ils sont en lambeaux par endroits, je n'aurai recours à aucune invention pour les rapiécer ou les joindre ; l'effort que j'apporterais à leur apprêt gênerait le dernier plaisir que j'espère trouver à les dire. ${ }^{63}$

Logo no início de La Porte étroite somos recebidos por um alerta desse je - que mais tarde descobriremos chamar-se Jérôme - a respeito da natureza do que estamos lendo. Isso não é um livro, diz ele. O aviso não é por um instante sequer adiado: outros, diz Jérôme já na primeira frase, poderiam ter feito disto um livro. Outros, não eu. E o que seria, então, La Porte étroite? Embora isso não seja indicado de forma clara, há aqui uma oposição à ideia de livro que dá pistas do que seria, para Jérôme, aquilo que ele escreve: escreverei muito simplesmente minhas lembranças, e se elas são por vezes inconsistentes, não recorrerei a nenhuma invenção para as emendar ou unir. Esse material a partir do qual outros poderiam ter feito um livro são as lembranças desse eu que escreve. Ele nada mais faz além de recordar escrevendo: diferentemente do pastor de La Symphonie pastorale, cuja narração é subordinada a uma situação de clausura e frio, em que nada mais pode ser feito para passar

\footnotetext{
63 "Outros poderiam ter feito disto um livro; mas a história que conto aqui, esgotei toda a minha energia vivendoa e minha virtude nisto se consumiu. Escreverei então muito simplesmente minhas lembranças, e se elas são por vezes inconsistentes, não recorrerei a nenhuma invenção para as emendar ou unir; o esforço que eu empregaria no seu acabamento estragaria o último prazer que espero encontrar em dizê-las." La Porte étroite. p. 11.
} 
o tempo, Jérôme começa a escrever, simplesmente, sem sentir a necessidade de justificar a sua ação ou de situar-se no espaço em que a realiza. Exceto por um vago aqui. O dêitico não descreve coisa alguma, apenas aponta, de modo que Jérôme se vale dessa marcação linguística com a naturalidade de alguém que, numa conversa em que os corpos estão presentes, num espaço definido e evidente, diz aqui ${ }^{64}$. Aqui, leitor: você está lendo o que é esse aqui, você vê onde estamos, não preciso explicar nada. Para alguém que não dá uma definição senão negativa de sua escrita (isto não é um livro), o dêitico é a forma ideal de referenciar, ao mesmo tempo irredutível e muito imprecisa.

Esse primeiro parágrafo absorve o leitor para um espaço singular, ao passo que, na recusa demarcada em relação ao livro, indetermina as coordenadas de leitura concernentes a esse espaço singular. Não há no anúncio gênero definido a priori, tipologia: a escrita é tudo o que temos. Ela é inclusive o próprio assunto de todo esse primeiro parágrafo: escreverei muito simplesmente minhas lembranças, e se elas são por vezes inconsistentes, não recorrerei a nenhuma invenção para as emendar ou unir. Jérôme rejeita a consistência da escrita, que seria caracterizada, segundo suas palavras, por uma invenção que emenda ou une. Há um descosimento voluntário e pontual que é aqui anunciado como uma oposição ao livro. O livro, portanto, pressuporia uma invenção, uma energia construtiva cuja emenda e união são as características principais, e que são aqui dignas de menção.

\footnotetext{
${ }^{64}$ Benveniste interpreta o emprego do dêitico aqui como integrante do conjunto de indicadores que atestam a presença de um locutor no discurso, para além dos próprios pronomes je/tu: "cette référence constante et nécessaire à l'instance de discours constitue le trait qui unit à je/tu une série d' « indicateurs » relevant, par leur forme et leurs aptitudes combinatoires, de classes différentes, les uns pronoms, les autres adverbes, d'autres encore locutions adverbiales." "Essa referência constante e necessária à instância de discurso constitui o traço que liga a eu/tu uma série de "indicadores" que sinalizam, por sua forma e por suas aptidões combinatórias, classes diferentes, uns pronomes, outros advérbios e outras locuções adverbiais". "La nature des pronoms ". In : PLG I. p. 253. É daí que tiro a ideia de presença nas linhas introdutórias de La Porte étroite.
} 
Essas características associadas vagamente a uma ideia de livro podem remontar à lógica de uma certa racionalidade manifesta na Poética de Aristóteles, a qual Jacques Rancière retoma:

L'histoire est obligée de raconter les événements l'un après l'autre dans leur succession, tandis que la poésie sélectionne et ne retient des événements d'une vie que ce qui est susceptible d'entrer dans un schéma causal. Elle ne raconte pas des vies, elle constitue des intrigues, des enchaînements d'actions nécessaires ou vraisemblables. (...) Une disjonction s'établit ainsi entre « la vie » dans sa factualité et l'ordre du savoir rationnel. ${ }^{65}$

Há, para Rancière, uma disjunção que se produz entre $a$ vida em sua factualidade e a ordem do saber racional, que é, parece-me, da mesma ordem que a cisão que Jérôme retoma para justificar o seu relato. No trecho citado de La Porte étroite, vida, lembranças, fragmentos, se opõem a livro, esforço, invenção. Essa ideia de livro como uma construção inventada, um esforço arquitetural que pressupõe uma lógica determinada, é também muito próxima da escrita do romance, sintetizada no seguinte excerto de Le Degré zero de l'écriture, de Barthes:

Le passé simple signifie une création : c'est-à-dire qu'il la signale et qu'il l'impose. Même engagé dans le plus sombre réalisme, il rassure, parce que, grâce à lui, le verbe exprime un acte clos, défini, substantivé, le Récit a un nom, il échappe à la terreur d'une parole sans limite : la réalité s'amaigrit et se familiarise, elle entre dans un style, elle ne déborde pas le langage ${ }^{66}$

\footnotetext{
65 “A história é obrigada a narrar os eventos um depois do outro obedecendo à sua própria sucessão, enquanto a poesia seleciona e só retém dos eventos de uma vida aquilo que é suscetível de entrar num esquema causal. Ela não narra vidas, mas constitui intrigas, encadeamentos de ações necessárias ou verossímeis. (...) Uma disjunção se estabelece, assim, entre "a vida" na sua factualidade e a ordem do saber racional." Rancière, J. "L’historien, la littérature et le genre biographique", In: Politique de la littérature. p. 193.

66 "O passé simple significa uma criação: o que quer dizer que ele a indica e que a impõe. Mesmo engajado no mais sóbrio realismo, ele assegura, porque, graças a ele, o verbo exprime um ato fechado, definido, substantivado, a Narrativa tem um nome, ela escapa do horror de uma palavra sem limite: a realidade se afunila e se familiariza, ela entra num estilo, ela não transborda a linguagem". Barthes, R. Le Degré zéro de l'écriture. $\mathrm{p}$. 2.
} 
Não me parece de todo impróprio associar essas palavras de Roland Barthes sobre o romance francês do século XIX ao que Jérôme insinua ser um livro. O livro consistiria na palavra limitada, num ato cerrado e circunspecto, cuja principal fonte de ligação é o passé simple, o qual subordina as orações a uma passagem ao mesmo tempo cronológica e consequencial do tempo. E que designa, em seu todo, um mundo a cujos limites podemos ter acesso, um mundo que não escapa, um mundo que assegura. Diferente daquilo que Jérôme deseja escrever ${ }^{67}$. Jérôme nega então a familiaridade de uma integração totalizante do livro: segundo a sua breve introdução, ele não utilizará nenhum tipo de invenção construtiva que venha costurar aquilo que na memória, por si, se dá de forma inconsistente, aflora par lambeaux. E ele justifica a sua escolha: o esforço que eu empregaria no seu acabamento estragaria o último prazer que espero encontrar em dizê-las. O prazer em estruturar a história como ele bem entende é digno de nota, e é a única justificativa aqui apresentada para a sua escrita.

Não há, de fato, vínculo causal ostensivo entre as cenas contadas no livro. La Porte étroite é constituído de páginas preenchidas por blocos de palavras entre os quais existem muitos espaços: espaços materializados por brancos que separam esses blocos, como pequenas ilhas, mas também espaços interiores aos próprios blocos de palavras, como pequenos lagos no interior de pequenas ilhas. Esse segundo tipo de hiato é geralmente representado por reticências no meio dos parágrafos:

\footnotetext{
${ }^{67}$ Além disso, é a partir desse tipo de romance livresco e arquitetural que Gide escreve. O que quero dizer é que os autores que produzem esse tipo de romance - Balzac, Victor Hugo, Stendhal - constituem as condições de enunciação da escrita de Gide, no sentido que Foucault emprega o termo em Les mots et les choses. O romance é um dos espaços possíveis a partir do qual é facultada a escrita, e dentro do qual Gide se localiza (caminhando rumo às fronteiras que a ele se apresentam como tais naquele momento).
} 
mais comme aggravé notre amour.

au monotone cours commença où, Une vie un milieu très sonore, le moindre comme vie de nos cœurs s'entendait.

Quelques jours après le départ de ma tante un soir, à table, nous parlâmes d'elle - je me,
souviens :

"Quelle agitation! disons-nous. Se peut-il répit à son de la vie ne laissent pas plus de répit à son âme? Belle apparence de l'amour, que devient ici ton reflet? „... Car nous nous souvenions du mot de Goethe qui, parlant de voir se réféchir le mait : "Il serait beau de Et nous établissio monde dans cette âme. " hiérarchie estions aussitôt je ne sais quelle hierarchie, estimant au plus haut les facultés contemplatives. Mon oncle, qui s'était tu jusqu'alors, nous reprit en souriant tristement:

a Mes enfants, dit-il, mème brisée, Dieu reconnaitra son image. Gardons-nous de juger les hommes d'après un seul moment de leur scur, elle le qui vous déplait en ma pauvre connais, elle le doit a des événements que je sévèrement que vouvoir la critiquer aussi si plaisante de vous faites. Il n'y a pas qualité vieillir, se gâter a jeunesse qui ne puisse, à chez Félicie, n'était d'abous appelez : agitation, prime-saut, chait d'abord qu'élan charmant n'étions pas bien différents, et grâce... Nous de ce que vous paraissez aujourd'hui. J'étais assez pareil à toi, Jérôme; plus peut-être que asse le sais. Félicie ressemblait beaucoup à e ne le sais. ment même - et brusquement je la retrouve, jouta-t-il en se tournant vers sa fille, dans certains éclats de ta voix; elle avait ton sourire - et ce geste, qu'elle a bientôt perdu, de rester comme toi, parfois, sans rien faire, assise, les coudes en avant, le front buté dans les doigts croisés de ses mains.

Miss Ashburton se tourna vers moi, et presque a voix basse :

"Ta mère, c'est Alissa qui la rappelle."

L'été, cette année, fut splendide. Tout semblait pénétré d'azur. Notre ferveur triomphait du mal, de la mort; l'ombre reculait devant nous. Chaque matin j'étais éveillé par ma joie ; je me levais dès l'aurore, à la rencontre du jour m'élançais... Quand je rêve à ce temps, je le revois plein de rosée. Juliette, plus matinale que sa sœur qui prolongeait très tard ses veillées, descendait avec moi dans le jardin. Entre sa sœur et moi elle se faisait messagère ; je lui racontais interminablement notre amour et elle ne semblait pas se lasser de m'entendre. Je lui disais ce que je n'osais dire à Alissa devant qui, par excès d'amour, je devenais craintif et contraint. Alissa semblait se prêter craintif et contraint. Ae je parlasse si gaiement

O caráter lacunar é inclusive explicitado na história contada por meio de um amigo de Jérôme que escuta a sua confissão: à vrai dire, il y a dans ton histoire quelque chose que je ne m'explique pas bien; tu n'as pas dû tout me raconter... ${ }^{68}$.

Mas o descosimento não implica que a história se construa, por consequência, na ausência de todo e qualquer fio condutor. Primeiro porque não são raros os momentos em que, mesmo após um branco na página, a narrativa continue avançando de modo linear: o que foi dito antes da pausa é retomado depois dela. Isso significa que Jérôme não se esquiva completamente da forma do livro, como anunciado no parágrafo introdutório; o caráter

68 "Para dizer a verdade, tem algo na sua história que não consigo entender; você não deve ter me contado tudo..." La Porte étroite. p. 58. 
fragmentário das lembranças consiste num traço como que tímido e inconstante. A expectativa que ele cria com o seu anúncio não é inteiramente satisfeita no desenrolar da escrita. Não é que ele não cumpra de todo o seu desejo de não vincular as cenas, mas apenas que, embora negue o livro, a sua escrita se organiza como que num espaço de livro: há algo de pertencimento e de não pertencimento a essa forma estabelecida.

Além disso, mesmo as partes mais propriamente lacunares são orientadas por um fio condutor: a escolha de cenas dá-se, a meu ver, por sua potencial excentricidade, que unifica a natureza daquilo que é contado. Já encontramos uma dessas excentricidades logo nas primeiras páginas, quando Jérôme introduz a narrativa dos verões que passava com a família na casa de sua tia Lucile Bucolin. Muitas frases de La Porte étroite são habitadas pelo estabelecimento de algo rotineiro no passado, através de verbos no tempo imperfeito: je vivais auprès de ces deux femmes à l'air également doux et triste ${ }^{69}$, j'étais de santé délicate ${ }^{70}$, presque toutes les heures du jour que nous ne passions pas au jardin, nous les passions dans "la salle d'étude ${ }^{71}$. Esses imperfeitos consolidam uma rotina que será invariavelmente quebrada, de modo que emerja a cena excepcional. Dentro do contexto das férias passadas na casa da tia, que se repetem ao longo dos anos, Jérôme pontua a cena marcante:

Un jour de cet été - ou de l'été suivant, car dans ce décor toujours pareil, parfois mes souvenirs superposés se confondent - j'entre au salon chercher un livre ; [ma tante] y était. J'allais me retirer aussitôt ; elle qui, $\mathrm{d}^{\prime}$ ordinaire, semble à peine me voir, $\mathrm{m}^{\prime}$ appelle. ${ }^{72}$

\footnotetext{
${ }^{69}$ Ibid. p. 12.

70 Idem.

71 Ibid. p. 14.

72 “Um dia desse verão - ou do verão seguinte, uma vez que nesse cenário sempre parecido, por vezes minhas lembranças superpostas se confundem - eu entro no salão buscar um livro; [minha tia] estava lá. Eu ia me retirar tão logo; ela que, geralmente, mal parece me ver, me chama." La Porte étroite. p. 19.
} 
Introduzi o trecho comentando que Jérôme pontua uma cena marcante, mas isso, após a leitura do excerto, deve ser relativizado. Jérôme instala a sua memória com tal despreocupação temporal, que o cerceamento da cena ocorre apenas através de um dia desse verão - ou do verão seguinte. Ele inclusive levanta uma ressalva com relação à veracidade da data: nesse cenário sempre parecido, por vezes minhas lembranças superpostas se confundem. Por algum motivo, o que se registrou em sua cabeça não foi a exatidão do ano no calendário, mas o lugar do acontecimento: o salão, que funcionava como uma pequena biblioteca e que consistia no principal passatempo de Jérôme durante as temporadas na tia. Depois desse súbito encontro, numa atmosfera de fascínio e medo de Lucile Bucolin ${ }^{73}$, ele pensa imediatamente em deixar a biblioteca. Mas logo acrescenta: ela que, geralmente, mal parece me ver, me chama. Após uma oração alagada pelo advérbio geralmente - a indiferença da tia em relação à presença do sobrinho -, somos conduzidos até a beira de uma rachadura nesse solo uniforme e alagado, em que o acúmulo do geralmente pode escoar: ela me chama. A frase é, assim, na sua própria base, estruturada para que aconteça alguma coisa fora do comum. Em termos de tempos verbais, é digno de nota que isso que será relatado se introduz na singularidade do tempo presente e não mais na resignação imperturbada do imperfeito. Além da relevância do espaço sobre a data do calendário, a marcação temporal que dirige a escrita está inteiramente concentrada no instante excêntrico.

Acompanhemos a continuação da cena:

" Pourquoi t'en vas-tu si vite ? Jérôme ! est-ce que je te fais peur ? " Le cœur battant, je m'approche d'elle; je prends sur moi de lui sourire et de lui tendre la main. Elle garde ma main dans l'une des siennes et de l'autre caresse ma joue.

\footnotetext{
73 “J'éprouvais un singulier malaise auprès de ma tante, un sentiment fait de trouble, d'une sorte d'admiration et d'effroi". "Eu experimentava um mal estar singular perto da minha tia, um sentimento composto de embaraço, de uma espécie de admiração e de assombro". La Porte étroite. p. 18.
} 
"Comme ta mère t'habille mal, mon pauvre petit !... »

Je portais alors une sorte de vareuse à grand col, que ma tante commence de chiffonner.

" Les cols marins se portent beaucoup plus ouverts ! dit-elle en faisant sauter un bouton de chemise. - Tiens ! regarde si tu n'es pas mieux ainsi ! " et, sortant son petit miroir, elle attire contre le sien mon visage, passe autour de mon cou son bras nu, descend sa main dans ma chemise entrouverte, demande en riant si je suis chatouilleux, pousse plus avant... J'eus un sursaut si brusque que ma vareuse se déchira ; le visage en feu, et tandis qu'elle s'écriait :

« Fi ! le grand sot ! » je m'enfuis. ${ }^{74}$

Essa continuação recupera uma cena inesquecível para Jérôme, obscura para a sua compreensão infantil e que, ademais, não é esclarecida pela escrita adulta. Em alguma medida, as memórias mantêm a falta de distanciamento, o raio curto de visão do próprio momento: elas não procuram ir adiante, tampouco explicar ${ }^{75}$. Jérôme presentifica - e não relembra, de forma pacífica e apaziguada - a cena em que a tia o chama para perto de si, amarrotando a sua roupa, alarmando a criança com a cena do botão da camisa. Ele corre para o jardim e o momento termina, simplesmente. Como uma rachadura no solo: ao mesmo tempo em que o instante singular abre uma ruptura na planificação dos verões sempre iguais na casa da tia, essa ruptura não escava um poço ou um túnel, a narrativa não passa a se

\footnotetext{
74 "Por que vai tão depressa? Jérôme! Você tem medo de mim?" Com o coração batendo, me aproximo dela; aproveito para sorrir e the estender a mão. Ela segura minha mão numa das suas e com a outra acaricia minha bochecha. "Como sua mãe te veste mal, minha pobre criança! ...". Eu vestia então uma espécie de jaqueta de gola alta, que minha tia começa a amarrotar. "As golas de marinheiro se usam muito mais abertas! Disse ela abrindo um botão da camisa. - Aqui! Veja se você não está melhor assim!" e, tirando seu pequeno espelho, ela puxa o meu rosto contra o seu, passa em torno do meu pescoço o seu braço nu, desce a sua mão por baixo da minha camisa entreaberta, pergunta rindo se eu sinto cócegas, desce ainda mais... Eu levei um susto tão grande que minha blusa rasgou; a face em chamas, e enquanto ela exclamava: "Humpf! Que bobão!" Eu saí correndo." La Porte étroite. pp. 19-20.

${ }^{75}$ Falando sobre os Diários de Gide, Éric Marty pontua esse mesmo efeito de presentificação pela escrita, que originou minha associação com La Porte étroite: "Gide évite que l'événement ne soit saisi par la mémoire, ne soit synthétisé, écrasé, relié à d'autres événements par une conscience généralisante, il se donne les moyens de préserver l'événement dans sa présence unique, encore retentissante, il le soustrait à toute analogie corruptrice ou abâtardissante, il le livre tel quel, inentamé". "Gide evita que o evento seja abarcado pela memória, sintetizado, esmagado, religado a outros eventos por uma consciência generalizante, ele forja para si mesmo formas de preservar o evento na sua presença única, que ainda ressoa, ele o subtrai de toda analogia que degenera, corrompe, e o oferece tal e qual, intacto". L'écriture du jour. Le journal d'André Gide. p. 13.
} 
desenvolver subterraneamente. Não é por acaso que Gide recua diante de suas duas primeiras ideias de título para esse livro, La voie étroite ( $A$ via estreita) ou La Route étroite ( $A$ rota estreita $)^{76}$. A via e a rota o comprometeriam em empreitadas mais prolongadas, e era preciso, a título de experimentação, libertar-se da promessa para com uma forma longa, era preciso encurtar, manter o valor apenas de um convite, de uma entrada. A rachadura no solo, que mencionei, não é mais do que isso, uma abertura estreita, uma fresta. Há, nisso sim, a presença do anúncio primeiro das memórias de reencontrar o prazer em dizer as lembranças, sem fazer delas um livro. Não há outro motivo para aquilo que Jérôme conta senão a excepcionalidade do que ele viveu, o seu caráter corporal, alarmante e jamais enunciado até o fim.

A excepcionalidade é um aspecto tão proeminente em La Porte étroite, que ela deixa a sua marca até mesmo nos espaços da casa. Já na cena que analisei por último, Jérôme corre para o jardim para ficar sozinho. São inúmeros os momentos em que as personagens se recolhem, seja para uma conversa secreta, seja para que possam se isolar dos espaços comuns da casa, em que se reúne o resto da família, para refletirem sozinhas:

Juliette, plus matinale que sa sœur qui prolongeait très tard ses veillées, descendait avec moi dans le jardin. Entre sa sœur et moi elle se faisait messagère ; je lui racontais interminablement notre amour et elle ne semblait pas se lasser de m'entendre. Je lui disais ce que je n'osais dire à Alissa devant qui, par excès d'amour, je devenais craintif e contraint. ${ }^{77}$

\footnotetext{
${ }^{76}$ Anglès, A. « Six personnages em quête d'une revue ", In : op. cit., Vol I. p. 16.

77 “Juliette, mais matinal que sua irmã, que prolongava até muito tarde o seu momento de despertar, descia comigo até o jardim. Entre a sua irmã e eu ela se fazia mensageira; eu lhe contava interminavelmente nosso
} 
O espaço reservado às intermináveis declarações de amor indiretas de Jérôme para a prima Alissa - pelo intermédio de Juliette - é o jardim, onde essa confidência, oprimida dentro do espaço da casa, pode se ampliar de maneira livre e irrestrita. É aliás fundamental que a confissão no jardim seja aqui introduzida, tanto tornou-se um hábito, naqueles eventos contados no imperfeito: Juliette, mais matinal que sua irmã, que prolongava até muito tarde o seu momento de despertar, descia comigo até o jardim. A divisão entre espaços públicos e privados dentro da própria casa é um costume adquirido.

Ao jardim, como o lugar de conversas secretas ou de evasão, opõem-se o vestíbulo, a antessala e o salão, ocupados pelas festas e reuniões:

L'arbre de Noël que préparait ma tante Plantier réunissait chaque année un grand nombre d'enfants, de parents e d'amis. Il se dressait dans un vestibule formant cage d'escalier et sur lequel ouvraient une première antichambre, un salon et les portes vitrées. ${ }^{78}$

A árvore do vestíbulo é sujeito do verbo reunir, figurando uma multidão acumulada em relação à qual Jérôme se torna tão refratário: ele está demasiado preenchido pelo seu amor secreto pela prima, de modo que a convivência com os outros se torna sempre muito penosa. Como nessa cena em que ele tenta esclarecer uma conversa obscura com Alissa:

Elle me quitta brusquement. Du monde entra qui me sépara d'elle. Je pensais la rejoindre dans le salon; je l'aperçus à l'autre extrémité de la pièce, entourée d'une bande d'enfants dont elle organisait les jeux. Entre elle et moi je reconnaissais diverses personnes auprès de qui je n'aurais pu

amor e ela não parecia se cansar de me ouvir. Eu dizia a ela aquilo que não ousava dizer à Alissa, diante de quem, por excesso de amor, eu me tornava temeroso e constrangido". Ibid. p. 45.

78 "A árvore de Natal que preparava minha tia Plantier reunia a cada ano um grande número de crianças, de parentes e de amigos. Ela se erguia num vestíbulo no vão da escada sobre o qual se abria uma primeira antessala, um salão e os vitrais." Ibid. p. 75. 
m'aventurer sans risquer d'être retenu; politesses, conversations, je ne m'en sentais pas capable ; peut-être qu'en me glissant le long du mur... J'essayai.

Comme j'allais passer devant la grande porte vitrée du jardin, je me sentis saisir par le bras. Juliette était là, à demi cachée dans l'embrasure, enveloppée par le rideau.

" Allons dans le jardin d'hiver, dit-elle précipitamment. Il faut que je te parle. Va de ton côté ; je t'y retrouve aussitôt. " ${ }^{79}$

Jérôme está angustiado por, num momento determinante de uma conversa com Alissa, ela deixá-lo bruscamente. Essa inadvertida ausência é para ele a coisa mais aterradora do mundo, sobretudo diante da reunião de toda a família, que se junta para uma comemoração: entre ela e eu, eu reconhecia diversas pessoas perto de quem eu não poderia me aventurar sem arriscar ser retido; cortesias, conversas, eu não me sentia capaz. Mas, ao elaborar uma estratégia de fuga pela borda da sala, colado na parede, Jérôme é interrompido por Juliette que, escondida atrás da cortina, parece ter algo importante e igualmente secreto para dizer ao primo. Por essa razão, ela o convoca para uma reunião de última hora no jardim de inverno, para onde ambos vão, cada um de um jeito, para que possam ficar sozinhos.

Um traço fundamental da divisão dos cômodos da casa de Lucile Bucolin é a possibilidade de algo poder ou não ser dito ali: a repartição interna à casa designa também uma repartição de palavras. O espaço, em La Porte étroite, está organizado segundo certas convenções intrínsecas das personagens a respeito daquilo que vai sair de suas bocas, o que quer dizer que a sala, o vestíbulo, o jardim são menos os locais habituais do passeio, das brincadeiras, das refeições, do que materializações de um espaço de palavras. É possível, a

\footnotetext{
79 “Ela me deixou bruscamente. Uma multidão entrou que me separava dela. Eu pensava em reencontrá-la no salão; eu a vi na outra extremidade do cômodo, cercada de um grupo de crianças para as quais ela organizava as brincadeiras. Entre ela e eu, eu reconhecia diversas pessoas perto de quem eu não poderia me aventurar sem arriscar ser retido; cortesias, conversas, eu não me sentia capaz; talvez me espreitando pela parede... Eu tentei. Quando eu ia passar diante da grande porta de vidro do jardim, me senti pegar pelo braço. Juliette estava lá, meio escondida pelo vão, envolvida pela cortina. 'Vamos para o jardim de inverno, disse ela precipitadamente. Preciso falar com você. Vá primeiro; eu te encontro em breve'." Ibid. p. 79.
} 
partir dessa leitura, desenhar uma planta da casa de Lucile Bucolin e preenchê-la segundo os paradigmas discursivos que regem os cômodos: vestíbulo de conversas desimportantes, jardim para confissões, quarto destinado ao diálogo consigo mesmo.

E o que mais é o aqui de Jérôme no parágrafo introdutório senão uma coordenada espacial para se referir, não a um lugar, mas a um amontoado de palavras? E o que é a clausura solitária do pastor de La Symphonie pastorale dentro de casa senão a possibilidade de finalmente dizer a sua confissão? 


\section{Minhas próprias cordilheiras}

Em La Symphonie pastorale, o espaço de enunciação do je é um espaço de contradição e de aparições, numa tentativa incessante de fazer com que associações inexplicáveis sejam incorporadas ao artifício da explicação. É como se esse espaço de enunciação supusesse que os trajetos das frases se orientassem segundo um vínculo causal. Esse é o a priori da escrita do pastor, o espaço efetivo em que ele se localiza: vou escrever como fui levado a tomar conta de Gertrude e preciso fazê-lo de forma ordenada, compreensível, preciso explicar tudo, inclusive o meu ímpeto de começar a escrever sobre esse acontecimento. Mas isso não significa absolutamente que, tendo esse espaço como a priori, ele não possa se esquivar de cada uma de suas determinações. O que quero dizer é que o pastor até se explica, até se retrata, mas nada disso impede que, sob as suas decisões, se dissimule uma arbitrariedade extremamente pessoal, apaixonada, e que é por ele ancorada na ideia de uma intervenção divina.

Jérôme habita a mesma região em que reina o vínculo causal e estreito, já com as malas prontas para fugir dali: não vou me construir segundo essas regras, não vou escrever livro nenhum. Mas a recusa total de sua origem é impossível. Vejo-o através da forte irregularidade que a escrita de La Porte étroite apresenta no que concerne à não-linearidade: por vezes as cenas estão soltas, livres, mas por vezes o vínculo causal e narrativo prevalece. Sartre o formulou muito acuradamente a propósito da obra de Gide de modo geral, em "Gide Vivant": I'art de Gide veut établir un compromis entre le risque et la règle ${ }^{80}$. Assim, o espaço

\footnotetext{
80 "A arte de Gide quer estabelecer um compromisso entre o risco e a regra". Sartre, J-P. "Gide vivant", In: Les temps modernes, $\mathrm{n}$ ㅇ66. Disponível em: http://e-gide.blogspot.com.br/2013/04/gide-vivant-par-j-p-sartre.html Acesso em: 01/08/2014.
} 
que esse je encontra como fuga possível da determinação do livro - que é figurado, em $L a$ Porte étroite, no espaço da excepcionalidade inexplicável - é extremamente apertado. Tão apertado, que Jérôme é repetidamente levado a retornar ao conforto da habitação antiga, em que há vinculação das memórias, continuidade.

Ambos os espaços das subjetividades que aqui se escrevem desejam portanto viajar rumo a um espaço disperso, singular e não articulado, como o espaço de Georges Poulet. Mas, assim como em Les Nourritures terrestres todo espaço não passa de uma enumeração - como os terrenos de um mapa -, essa destinação almejada, em La Porte étroite e La Symphonie pastorale, é apenas uma seta, não um real destino. Há, no espaço de origem (do vínculo e da totalidade), uma primeira força de gravidade demasiado magnética impedindo a viagem para outras regiões, que se mantém sob a forma de uma promessa para o futuro.

Esses dois jes se posicionam, então, numa área bastante indeterminada: eles se sobrepõem a uma região plana, por todos conhecida e já há muito estabilizada, que se revela contudo demasiadamente insatisfatória. Diante de tais circunstâncias, eles sentem a necessidade de conturbar a estabilidade prévia, alçando-se sobre algo diverso e novo. Só que essa novidade não chega a constituir nenhum ponto de chegada, nenhum destino de viagem, o que quer dizer que esses jes não encontram na sua peregrinação qualquer forma de se acomodar, eles não têm nenhum sossego. São, precisamente, como montanhas: irregularidades reinantes as quais se impõem sobre uma origem perceptivelmente plana do solo, mas que não passam de um império arbitrário e transitório. Montanhas se formam e diante da perfuração contínua das raízes que nelas se apoiam, das avalanches contínuas de gelo do pico das montanhas, da incansável atividade do clima ou mesmo da contínua empreitada humana - elas desaparecem. O solo, um dia, volta a se estabilizar, ele com certeza, 
um dia, dentro de milhares de anos, volta a corrigir-se ${ }^{81}$. Montanhas são um estágio indeciso e alarmante da existência.

É muito importante que tudo que tenha sido dito gire em torno de um je. A escrita em primeira pessoa, em Gide, só encontra razão de ser enquanto há algo labiríntico, alarmante, excepcional para ser dito: são exatamente esses os aspectos que promovem a reunião desses jes. Aliás, os eixos de construção que observei em La Porte étroite e La Symphonie pastorale constituem um vasto campo no qual se localizam muitos textos de Gide construídos a partir de um je, como condições que possibilitam que esse je se afirme a cada vez. Gostaria de passar rapidamente por alguns exemplos antes de me deslocar efetivamente para a próxima região.

L'Immoraliste, livro publicado poucos anos depois de La Porte étroite ${ }^{82}$, e frequentemente analisado como uma duplicidade em relação a este último ${ }^{83}$, é outra narrativa de Gide em que há uma história contada do ponto de vista de um je, Michel. Tratase de um je em alguma medida apaziguado por aquilo que habitualmente denomina-se discurso indireto: Michel conta a sua história a um amigo que a reproduz inteiramente numa carta, destinada ao círculo de amigos íntimos de ambos. Nós lemos, não as palavras de Michel, mas a sua reprodução na carta. O cerne da história contada se concentra na narração de seu

\footnotetext{
${ }^{81}$ Doran, T. The Weight of Mountains. Disponível em: http://vimeo.com/87651855

82 L'Immoraliste é de 1902 e La Porte étroite, de 1909. Com essa aproximação histórica, sugiro que haja alguma semelhança entre os dois projetos, embora isso não constitua, de forma alguma, uma regra em Gide. Ele pode escrever duas coisas muito similares, como também dois livros absolutamente diferentes entre si numa mesma época, como é o caso de Les Nourritures terrestres (1917) e Les Caves du vatican (1922).

83 É o que fazem, por exemplo, Roland Barthes em "Notas sobre André Gide e seu Diário", ao denominar essas duas narrativas de "díptico" (p. 12), e Scott Manning, em "Revelation and dissimulation in André Gide's autobiographical space", chamando essas duas narrativas de "early récits", com muitos pontos de convergência entre si (como, por exemplo, o ocultamento de partes importantes das histórias, p. 318).
} 
casamento, na sua doença e na subsequente convalescença, seguida das viagens em companhia da esposa, Marceline. Mas algo estranho sobrevoa esse casamento a todo momento:

Mes rapports avec Marceline demeurèrent donc, en attendant, les mêmes - quoique plus exaltés de jour en jour, par un toujours plus grand amour. Ma dissimulation même (si l'on peut appeler ainsi le besoin de préserver de son jugement ma pensée), ma dissimulation l'augmentait. Je veux dire que ce jeu m'occupait de Marceline sans cesse. Peut-être cette contrainte au mensonge me coûtât-t-elle un peu d'abord ; mais j'arrivai vite à comprendre que les choses réputées les pires (le mensonge, pour ne citer que celle-là) ne sont difficiles à faire que tant qu'on ne les a jamais faites ; mais qu'elles deviennent chacune, et très vite, aisées, plaisantes, douces à refaire, et bientôt comme naturelles. ${ }^{84}$

Michel, nessas linhas, aproxima uma série de ideias opostas que, no seu casamento, podem conviver: as declarações de amor e a dissimulação do amor, o esforço da mentira e o prazer da mentira. Estruturalmente, o excerto caminha como um ziguezague ou um labirinto: em oito linhas, existem cinco operadores de contradição ou de ressalva. Primeiramente, os mais evidentes mas, que opõem com clareza uma coisa à outra (o esforço da dissimulação ao aprendizado de que elas podem ser prazerosas: as coisas tidas como as piores só são difíceis de executar se nós nunca as executamos; mas elas se tornam cada uma, e muito rapidamente, fáceis, prazerosas, agradáveis de serem refeitas, e tão logo como que naturais). E, depois, certos operadores que fazem incidir sobre o relato a ideia de restrição sem escancará-la, como no caso do talvez (talvez essa restrição à mentira tenha me custado um pouco no início), que

\footnotetext{
84 "Minha relação com Marceline permaneceu então, nesse meio tempo, a mesma - ainda que diariamente exaltada por um amor sempre crescente. Minha própria dissimulação (se podemos chamar assim a necessidade de preservar minha reflexão de seu julgamento), minha dissimulação o aumentava. Quero dizer que este jogo me ocupava de Marceline incessantemente. Talvez essa restrição à mentira tenha me custado um pouco no início; mas cheguei logo a compreender que as coisas tidas como as piores (a mentira, para não citar senão esta) só são difíceis de executar se nós nunca as executamos; mas que elas se tornam cada uma, e muito rapidamente, fáceis, prazerosas, agradáveis de serem refeitas, e tão logo como que naturais." L'Immoraliste. p. 71.
} 
adiciona um pequeno obstáculo em relação à ideia exposta antes - já com certa inconstância, pelo ainda que - de que o vínculo de Michel e Marceline os dirigia rumo a uma felicidade crescente.

O sentido, aqui, não é construído a partir do acréscimo de uma ideia à outra, como uma bola de neve, mas sim a partir de despojamentos e subtrações, como uma linha que se puxa de um novelo: algo é enunciado para que, logo em seguida, uma outra coisa venha restringir a sua preponderância, desviar o sentido através de ressalvas, contradizer. Além disso, não há propriamente uma simetria estabelecida pelas partículas adversativas, isto é, elas não separam antagonismos. Ao invés disso, elas introduzem algo inesperado: opõe-se ao esforço da dissimulação o prazer, mas dissimulação e prazer não constituem semanticamente antônimos. O que significa que há, aqui também, uma tendência à excepcionalidade. Esse je, não obstante a peculiaridade de sua situação, e também a distância introduzida pela narrativa indireta, tem algo de similar àqueles de La Symphonie pastorale e La Porte étroite, no sentido de que ele também se constrói de forma contraditória e excêntrica.

Essa maneira como que acidentada por meio da qual o je se coloca está em toda parte, como por exemplo nas duas reuniões de memórias de Gide, Si le grain ne meurt e Ainsi soit-il ou les jeux sont faits. No primeiro livro, Gide elabora frases tais como: pour moi je ne puis dire si quelqu'un m'enseigna ou comment je découvris le plaisir ; mais, aussi loin que ma mémoire remonte en arrière, il est là ${ }^{85}$. Ou ainda:

Roger Martin du Gard, à qui je donne à lire ces Mémoires, leur reproche de ne jamais dire assez, et de laisser le lecteur sur sa soif. Mon intention pourtant a toujours été de tout dire. Mais il est un degré dans la

\footnotetext{
85 "Eu mesmo não saberia dizer se alguém me ensinou ou como eu descobri o prazer; mas, tão longe minha
} memória pode voltar, ele está lá". Si le grain ne meurt. p. 10. 
confidence que l'on ne peut dépasser sans artifice, sans se forcer ; et je cherche surtout le naturel. ${ }^{86}$

É como se ele só pudesse enunciar o que quer que fosse com a condição de que esse enunciado surgisse como uma oposição a algo estabelecido antes (não posso dizer como descobri o prazer; Roger Martin du Gard me desaprova; minha intenção sempre foi dizer tudo). Esses estabelecimentos todos funcionam como uma espécie de trampolim do discurso.

Outros dois exemplos de Ainsi soit-il ou les jeux sont faits: je suis, pour obtenir ce que je veux, tenace, hardi, téméraire même et sans regards pour les obstacles ; mais pour résister à ce que les puritains appellent « la tentation », je ne vaux rien. ${ }^{87}$ Ou ainda:

Si j'avais à recommencer ma vie et qu'il me fût loisible d'en disposer à plaisance, à la manière dont je vois les choses aujourd'hui, j'y donnerais sans doute plus de temps au travail (j'entends : à celui de mon instruction) mais sûrement plus de temps à l'aventure. ${ }^{88}$

É preciso que sempre haja algum tipo de curva nas frases, de esquina, de oposição que dê vazão ao que se deseja dizer. Em suma, a escrita em primeira pessoa leva, em Gide, a uma obsessão pela forma contraditória do mas: essa conjunção não é apenas um modo de vincular dois pensamentos distintos numa organização ulterior, mas a forma em si dentro da qual se orienta o seu pensamento, dentro da qual ele exclusivamente se constrói. Por mais que os jes de La Symphonie pastorale, La Porte étroite, L'Immoraliste, Si le grain ne meurt e Ainsi soit-il

\footnotetext{
86 "Roger Martin du Gard, a quem dou a ler essas Memórias, lhes reprova o fato de não dizerem jamais o bastante, e de deixarem o leitor ávido por mais. Minha intenção no entanto sempre foi de dizer tudo. Mas há um grau na confidência que não se pode ultrapassar sem artifício; e eu busco sobretudo o natural”. Ibid. p. 280. 87 “Eu sou, para obter o que quero, tenaz, ousado, mesmo imprudente e sem vistas para os obstáculos; mas para resistir àquilo que os puritanos chamam "tentação", eu não valho nada." Ainsi soit-il ou les jeux sont faits. p. 54. 88 "Se eu tivesse que recomeçar minha vida e que me fosse permitido distribuí-la a meu bel prazer, à maneira segundo a qual vejo as coisas hoje, eu daria talvez mais tempo ao trabalho (e com isso quero dizer: àquele da minha instrução) mas certamente mais tempo à aventura." Ibid. p. 37
} 
ou le jeux sont faits sejam muito diversos entre si e únicos a cada vez, eles parecem todos moradores de uma mesma casa, ou alpinistas de um mesmo conglomerado de montanhas.

Philippe Lejeune, no capítulo destinado a Gide em Le pacte autobiographique, apreende a dispersão e as contradições do je na autobiografia:

On ne peut assumer sa vie sans d'une certaine manière en fixer le sens ; ni l'englober sans en faire la synthèse ; expliquer qui on était, sans dire qui on est. Mis à part l'engagement, tous ces autres aspects de l'autobiographie répugnent à Gide très profondément. L'idée de la " connaissance de soi " lui semble un piège : elle implique limitation et artifice. Il ne saura se résoudre ni à se démasquer, ni à se peindre au présent, ni à choisir, ni à conclure, ni, simplement, à tout dire. (...) Si le grain ne meurt est le produit paradoxal de deux exigences contradictoires, un essai pour concilier les avantages de l'aveu et le refus des structures de la personne et du discours que suppose l'autobiographie classique. ${ }^{89}$

Aqui, Lejeune põe em relevo a exigência do discurso uno e coerente de um eu, que funciona como uma espécie de síntese tradicionalmente associada à autobiografia, e que é, para ele, tudo aquilo de que Gide escapou durante toda a sua vida: Gide não saberia se resolver nem se desmascarar, nem pintar-se no presente, nem escolher, nem concluir, nem dizer tudo. Ao mesmo tempo, subsiste uma outra demanda, que contradiz a primeira,

\footnotetext{
89 “Não se pode assumir a própria vida sem de uma certa maneira fixar o seu sentido; nem englobá-la sem fazer a sua síntese; explicar quem se era, sem dizer quem se é. Posto de lado o engajamento, todos esses outros aspectos da autobiografia são muito profundamente repugnantes para Gide. A ideia do "conhecimento de si" Ihe parece uma armadilha: ela implica limitação e artifício. Ele não saberia se resolver nem se desmascarar, nem pintar-se no presente, nem escolher, nem concluir, nem, simplesmente, dizer tudo. (...) Si le grain ne meurt é o produto paradoxal de duas exigências contraditórias, uma tentativa de conciliar as vantagens da confissão e a recusa às estruturas da pessoa e do discurso que supõe a autobiografia clássica". Lejeune, P. "Gide et l'espace autobiographique", In: Le pacte autobiographique. p. 174.
} 
presente na tentativa de conciliar com uma recusa às estruturas de pessoa e do discurso que supõe a autobiografia clássica as vantagens da confissão. Ou seja, Gide recusa uma coerência e uma unidade, que são normalmente tratadas como paradigmas da subjetividade, ao passo que insiste em reafirmar o seu je de maneira incansável, dentro de um espectro de vantagens da confissão. No raciocínio de Lejeune, a própria decisão de escrever sobre si mesmo é fruto de exigências contraditórias.

Roland Barthes traz também um aspecto paradoxal de Gide nas páginas de "Notas sobre André Gide e seu diário", em dois fragmentos intitulados "Fidelidade" e "Contradições":

Em que sentido, então, pôde mover-se essa natureza fiel, cujas obras, porém, deixam uma impressão de cambiância e mobilidade - a tal ponto que houve quem o acusasse de esquivar-se por inconstância? Aqui é preciso dissipar o preconceito da rigidez: certos espíritos chegam a parecer constantes à força de serem sempre inteiriços; escamoteiam suas guinadas (por mais consequentes que sejam), e de sua nova opinião só apresentam a face endurecida, que eles solidificam com alta dose de violência. A atitude de Gide diante destes é mais humilde e comedida. Com uma consciência que a moral comum tem o estranho hábito de chamar de doentia, ele se explica, se entrega, se retrata delicadamente ou então se afirma com coragem, mas não engana o leitor sobre nenhuma de suas mudanças; Gide põe tudo no movimento de seu pensamento, e não em sua brutal profissão. ${ }^{90}$

Gide não engana o leitor sobre nenhuma de suas mudanças: as suas transições serão, a cada vez, expostas, afirmadas corajosamente. Isso integra em seu cerne um movimento que, para Barthes, costuma ser interpretado como inconstância ou evasão, e que é precisamente aquilo que torna Gide um eu - precisamente, a sua fidelidade. Esse ponto, aliás, atravessa quase todos os fragmentos de "Notas sobre André Gide e seu Diário": quando Barthes cita

\footnotetext{
${ }^{90}$ Barthes, R. “Notas sobre André Gide e seu diário”, In: Inéditos, Vol II - Crítica. p. 9.
} 
Hegel numa defesa da contradição ${ }^{91}$, quando comenta o romance diabólico Les FauxMonnayeurs $^{92}$, ou ainda quando percebe que aquilo que mais marcou Gide na leitura de Goethe foi o das Schaudern - algo como o tremor, a oscilação ${ }^{93}$.

E o que seria oposto a essa mobilidade, a essa cambiância própria de Gide que é reafirmada a cada vez? Diz Barthes: certos espíritos chegam a parecer constantes à força de serem sempre inteiriços; escamoteiam suas guinadas (por mais consequentes que sejam), e de sua nova opinião só apresentam a face endurecida. Os espíritos que se obstinam na própria petrificação ocultam voluntariamente todas as suas transformações - ainda que sejam muito consequentes. Esse ainda que sugere que transformações consequentes poderiam, sem contradição, entrar na lógica dos espíritos constantes; que essa constância, assim, pressuporia uma lógica discursiva da consequência, de uma sequência consequente. Retorno ao espaço que procurava Poulet no início de seu texto, que, na sua forma tradicional e crua, implicava a necessidade de vínculos sequenciais, de uma totalidade que fosse capaz de tudo abarcar. Em Poulet, víamos que essa expectativa era frustrada logo no início: em Gide o espaço, em sua forma geral e nua, não existe. A mesma coisa no que concerne ao espírito gideano, para Barthes, que se explica, se entrega, se retrata delicadamente ou então se afirma com coragem, mas não engana o leitor sobre nenhuma de suas mudanças. Reunindo essas análises centradas em diferentes aspectos de Gide, é possível apreender um traço recorrente: todas elas

\footnotetext{
91 "Gostaria que aquele que criticam Gide por suas contradições (sua recusa a escolher como todos) se lembrassem desta página de Hegel: "Para o senso comum, a oposição entre verdadeiro e falso é algo fixo; ele espera que se aprove ou que se rejeite em bloco um sistema existente. Não concebe a diferença entre os sistemas filosóficos como o desenvolvimento progressivo da verdade; para ele, diversidade quer dizer unicamente contradição (...) O espírito que apreende a contradição não sabe libertá-la e conservá-la em sua unilateralidade, e reconhecer, na forma daquilo que parece entrechocar-se e contradizer-se, momentos mutuamente necessários" Ibid. pp. 7-8.

92 "Assim como Les Caves du Vatican, Les Faux-Monnayeurs são um romance diabólico; quero dizer que, sendo a unicidade da ação incessantemente rompida em proveito de perspectivas imprevisíveis e muitas vezes inexploradas, o que se tem é uma fantasia infernal". Ibid. p. 19.

${ }_{93}$ Ibid. p. 5.
} 
apontam para o fato de que a lógica da totalidade coesa não satisfaz Gide, ainda que ele tenha algum tipo de relação com ela (como a sua habitação inicial). Ainda que preexista a tudo o princípio da fidelidade.

A fidelidade é, inclusive, o termo que o próprio Gide emprega para descrever o seu ponto de vista posterior em relação a Les Nourritures terrestres:

J'ai tout aussitôt quitté celui que j'étais quand j'écrivais Les Nourritures ; au point que si j'examine ma vie, le trait dominant que j'y remarque, bien loin d'être l'inconstance, c'est au contraire la fidélité. Cette fidélité profonde du cœur et de la pensée, je la crois infiniment rare. ${ }^{94}$

É curioso como a distância entre a transformação imediata que nele se operou ao fim de Les Nourritures terrestres e o traço constante da fidelidade seja percorrida sem qualquer mediador de oposição: logo deixei aquele que eu era quando escrevia Les Nourritures; a ponto que, se examino minha vida, o traço dominante que percebo, bem longe de ser a inconstância, é ao contrário a fidelidade. Não se trata de opor as transformações ao caráter fiel, mas, isto sim, de uni-los num fio único, contínuo, como o seu traço dominante. Através da expressão a ponto que, a fidelidade é posicionada no ápice da montanha da contradição.

Em outro momento, Barthes cita um excerto do Journal em que Gide explica como a variedade de seus estados de espírito não está de modo algum submetida à passagem do tempo; pelo contrário, esses diferentes estados são fruto de uma convivência, de uma simultaneidade:

\footnotetext{
94 "Logo deixei aquele que eu era quando escrevia Les Nourritures; a ponto que, se examino minha vida, o traço dominante que percebo, bem longe de ser a inconstância, é ao contrário a fidelidade. Essa fidelidade profunda do coração e do pensamento creio que seja infinitamente rara". Les Nourritures terrestres. p. 12.
} 
Gide é (...) um ser simultâneo. É quase como se, no começo, tivesse sido dado completo pela Natureza. Depois, foi com calma expondo sucessivamente os diferentes aspectos de si mesmo, mas é sempre bom lembrar que esses aspectos na realidade são contemporâneos uns dos outros, como, aliás, suas obras. ${ }^{95}$

Gide vai expondo sucessivamente os diferentes traços de si, mas a sucessão é fruto apenas da impossibilidade de os estados se escreverem conjuntamente; em outras palavras, a ênfase de Barthes recai sobre uma concomitância de fundo que prevalece na escrita de Gide. Auguste Anglès também sugere que, para Gide, essa simultaneidade era fundamental, e que ela habitava todos os seus planos de escrita:

La seule obligation de les publier l'une après l'autre aurait créé l'apparence de leur succession et induit en erreur ceux qui lui ont imputé à crédit ou à débit une illusoire évolution. Contre cette tendance à le mettre en perspective il s'est constamment insurgé, et il n'a cessé de revendiquer son appartenance à l’ordre du simultané. ${ }^{96}$

É impossível colocá-lo em perspectiva, isto é, organizá-lo num texto linear, hierarquizálo. Gide pertence à ordem do simultâneo. Essa sincronia de obras múltiplas e de estados múltiplos que convivem chama menos atenção para o tempo - na simultaneidade, o tempo é uma monotonia - do que para o seu espaço de coabitação. Como se todos os livros pudessem ser postos um ao lado do outro e lidos, habitados de uma só vez, pensados todos de uma só vez $z^{97}$

\footnotetext{
95 “Notas sobre André Gide e seu diário". p. 7.

96 Op. Cit. p. 14.

97 É evidente que isso precisa, em alguma medida, ser relativizado: o tempo exerceu efeito sobre a escrita de Gide, como por exemplo a sua experiência na União Soviética (algo como uma maturidade, uma atenção maior para algo além dele mesmo). De todo modo, não é possível submeter a multiplicidade de aspectos de Gide, largamente diferentes uns dos outros, difusos, a uma lógica histórica, em que a História como discurso linear sobre os fatos se torne uma origem determinante e peremptória daquilo que é dito.
} 
Mas é preciso levantar uma ressalva importante: para Lejeune e Barthes, os textos analisados são exclusivamente as memórias e o Diário: gêneros que são um holofote projetado no eu. De modo que as suas asserções valem dentro de uma região circunscrita e que - ainda que de maneira decerto cuidadosa - conservam alguma ligação com a imagem de autor. Para Lejeune, na ideia de pacto autobiográfico; para Barthes, na sua identificação com a imagem do escritor Gide ${ }^{98}$. Não é que eu mesma não me identifique - aliás, em todos os pontos - com uma representação de Gide que crio para mim mesma, incansavelmente, ao longo de minhas leituras. Mas, ao ter escolhido analisar primeiro, e mais minuciosamente, dois livros ficcionais (La Symphonie pastorale e La Porte étroite), desejo atribuir uma ênfase um pouco diversa ao je, menos ligada a um elo autoral do que a um espaço que se funda a cada vez que se diz eu - o que, em certo sentido, se torna profusamente agregador. A subjetividade nos livros de Gide é também, nessa leitura, um ensinamento da língua, como qualquer subjetividade para Benveniste. O problema de um sujeito contraditório é ao mesmo tempo muito maior e muito menor do que aquele das memórias e do diário: é um problema de pronome, um problema do eu.

Lejeune já notou algo diverso do habitual na escrita de si em Gide, que está estampado no título de seu texto: "Gide e o espaço autobiográfico". Para Gide, não cabe mais falar em autobiografia, mas no espaço que por ela se pode criar. Assim, também não é possível, nas narrativas ficcionais, terceirizar a voz do je para a função de um narrador: esse je não pode ser visto com as sujas lentes de uma categoria crítica que fecha os olhos para as singularidades

\footnotetext{
98 "Duvido que o Diário desperte grande interesse se a leitura da obra não tiver previamente despertado curiosidade sobre o homem". Ibid. p. 1.
} 
de cada situação em que se diz eu. Os jes de Gide não são nem o autor, tampouco o narrador, mas um espaço, cordilheiras. 
Regiões: Falésias 


\section{Paisagem noturna}

O segundo capítulo do romance Les Faux-monnayeurs se inicia com o senhor

Profitendieu voltando do trabalho, em uma conversa com o colega Oscar Molinier. Do qual, aliás, não vê a hora de se livrar, com o objetivo de chegar em casa e tomar seu esperado banho, um momento extraordinário, e que por isso consiste no eixo de organização de todo o seu dia:

Monsieur Profitendieu était pressé de rentrer et trouvait que son collègue Molinier, qui l'accompagnait le long du boulevard Saint-Germain, marchait bien lentement. Albéric Profitendieu venait d'avoir au Palais une journée particulièrement chargée : il s'inquiétait de sentir une certaine pesanteur au côté droit ; la fatigue, chez lui, portait sur le foie, qu'il avait un peu délicat. Il songeait au bain qu'il allait prendre ; rien ne le reposait mieux des soucis du jour qu'un bon bain; en prévision de quoi il n'avait pas goûté ce jourd'hui, estimant qu'il n'est prudent d'entrer dans l'eau, fût-elle tiède, qu'avec un estomac non chargé. Après tout, ce n'était peut-être là qu'un préjugé ; mais les préjugés sont les pilotis de la civilisation. ${ }^{99}$

O senhor Profitendieu pensava no banho daquela noite, que o acalmaria mais do que qualquer outra coisa e cuja previsão, naquele dia, havia desencadeado a precaução de não ter tomado o lanche da tarde. Quem fala todas essas coisas? Naturalmente, o narrador: essa voz que tudo sabe e que cria ostensivas representações a partir da sua onisciência, que em outras circunstâncias poderia ser chamada simplesmente imaginação. O narrador onisciente é como

\footnotetext{
99 “O senhor Profitendieu tinha pressa em voltar para casa e achava que seu colega Molinier, que o acompanhava ao longo do bulevar Saint-Germain, andava muito devagar. Albéric Profitendieu acabava de passar por um dia particularmente cheio no Palácio: inquietava-se por sentir certo peso do lado direito; a fadiga, nele, atingia o fígado, que era um pouco delicado. Pensava no banho que tomaria; nada o descansava melhor das preocupações do dia que um bom banho; prevendo isso ele não havia tomado lanche naquele dia, estimando que não era prudente entrar na água, mesmo morna, senão com o estômago vazio. Afinal, isso talvez não fosse mais do que um preconceito; mas os preconceitos são os pilares da civilização." Les Faux-monnayeurs, p. 19 para o original e Os moedeiros falsos, pp. 19-20 para a versão em português. Trad. Mario Laranjeira.
} 
um apaixonado que trama sem parar, munido de uma energia incansável; que interpreta, obsessivo, cada olhar, cada enigma lançado por aquele a quem se dirige o seu amor. Lembrome dos Fragments d'un discours amoureux de Roland Barthes, no qual a figura de um apaixonado é engolida por uma espécie de ciclo vicioso da interpretação, que faz com que ele enclausure todas as suas percepções dentro de um único e invariável signo: ela/ele me ama de volta. Para o apaixonado tudo faz sentido. É a mesma utopia, uma utopia do sentido, que se esconde no cerne da onisciência: todos os acidentes esparsos nos quais tropeço encaminham-se para a mesma grande totalidade da vida ${ }^{100}$.

Eu já havia mencionado que talvez seja uma imprudência crítica partir do pressuposto de que o narrador, de saída, exista, exista sempre. Toda uma heterogeneidade de fenômenos pode se obscurecer pelas lentes imundas dessa categoria crítica, que integra o aprendizado mais elementar de qualquer aluno de Letras. Aprendemos a ler um narrador no romance como quem aprende a decifrar as letras do alfabeto combinadas em palavras na folha. 0 narrador é um pressuposto da leitura, como as letras são os pressupostos das palavras. Mas essa imprudência crítica é um risco irresistível no que concerne a Les Faux-monnayeurs. Isso porque é da categoria do narrador que parte a escrita do romance - como um fogo de artifício parte da terra para estourar no alto, despedaçar-se. O livro parte, precisamente, de uma prática narrativa comum aos escritores franceses do século XIX101, e faz a narração estourar no alto, onde se espalha despedaçada. Aliás, em Les Faux-monnayeurs, o caráter subversivo, o fogo de artifício do narrador, é um processo altamente evidenciado, quase didático; o

\footnotetext{
${ }^{100}$ Essa ideia - de que o mundo faz sentido - está presente também em todo o já mencionado capítulo sobre a Escritura do Romance em Le Degré zéro de l'écriture, de Roland Barthes, e é precisamente aquilo que servirá como base de oposição para o desenvolvimento da noção de écriture blanche, na análise de Camus.

${ }^{101}$ A propósito desse pressuposto, Lejeune diz o seguinte : « on a pu dire des Faux-Monnayeurs qu'ils étaient une sorte de festival du roman traditionnel, bien plus qu'une ouverture sur le roman moderne (par opposition à l'œuvre de Proust, de Joyce, de Kafka, ou de Faulkner) ». Le pacte autobiographique. pp. 184-5.
} 
próprio Gide procura justificar esse posicionamento infinitamente, seja na escrita do Journal des Faux-Monnayeurs, seja na ideia de um romance puro, surgida numa conversa entre Édouard, Sophroniska e Laura no capítulo "Édouard expose ses idées sur le roman"102. Eu poderia experimentar desenvolver essa analogia entre um tipo de narração próprio ao romance do século XIX francês e o fogo de artifício que ela vira no romance de Gide. No entanto, não é de meu interesse fazê-lo exatamente nesse momento ${ }^{103}$. Trago essa questão ao texto apenas como forma de pontuar a ideia da voz do narrador como uma voz suposta no romance (independentemente de como o temperamento do narrador irá, a cada vez, lidar com essa suposição).

E o que fala essa voz de narrador no excerto acima? Em primeiro lugar, ela resume algo dos hábitos de Profitendieu sumariamente, em larga escala: la fatigue, chez lui, portait sur le foie, qu'il avait un peu délicat. Il songeait au bain qu'il allait prendre ; rien ne le reposait mieux des soucis du jour qu'un bon bain. Nada o descansava melhor das preocupações do dia que um bom banho: o narrador que diz isso deve conhecer muito bem o senhor Profitendieu, cada momento do seu dia, o que ele pretende fazer em seu tempo livre, os hábitos de seu fígado. Como se, como uma segunda esposa, ele dormisse ao seu lado, dominasse indiscretamente todas as suas manias, as suas menores predileções, as estratégias capazes de acalmá-lo. Tudo

\footnotetext{
102 Édouard: Ce que je veux, c'est présenter d'une part la réalité, présenter d'autre part cet effort pour la styliser, dont je vous parlais tout à l'heure. Les Faux Monnayeurs, p. 184. Ainda que não seja meu objetivo nesse texto, sinto a necessidade de colocar em relevo que considerar de modo literal quaisquer palavras escritas (sejam as palavras da personagem romancista Édouard, sejam as palavras de Gide no Journal des Faux-Monnayeurs) é uma aposta demasiado incerta para o leitor. Não há palavra final, nunca se sabe onde está Gide. Não parece existir esforço maior, para ele, do que se esquivar. No caso do diálogo entre Édouard, Sophroniska e Laura, por exemplo, essa evaporação da voz autoral, de uma voz-eixo, surge através da ênfase na ridicularização da teoria do romance de Édouard, a ponto de Sophroniska e Laura terem de segurar o riso diante do pedantismo e da afetação do romancista.

${ }^{103}$ Além de que uma parte da crítica de Gide já cuidou disso. Penso, por exemplo, numa certa vertente do pensamento marxista que se interessa pelas possibilidades de narração na modernidade (Georg Lukács, em "O romance como epopeia burguesa", ou Theodor W. Adorno, em "Posição do narrador no romance contemporâneo"), ou mesmo numa parcela especializada da crítica de Gide (Regina Salgado Campos em "Gide e o questionamento do romance", Alain Goulet em seus dois livros sobre Les Faux-monnayeurs).
} 
isso só pode ter sido dito por alguém que o conhece muito bem, que não é o próprio Profitendieu, no entanto. Mas com cujas asserções ele poderia consentir, salvo, talvez, por algum escrúpulo de saber-se decifrado por um outro (algo previsível no caso de uma figura pública tão imponente, tão suntuosa quanto o senhor Profitendieu).

O que vem a seguir em termos de narração já se mistura um pouco mais com aquilo que o próprio senhor Profitendieu deve ter pensado pontualmente naquele dia, já estamos colados nele: en prévision de quoi il n'avait pas goûté ce jourd'hui, estimant qu'il n'est prudent d'entrer dans l'eau, fût-elle tiède, qu'avec un estomac non chargé. Ele mesmo, ao ter escolhido não tomar o lanche da tarde, pode ter se justificado aos próprios olhos com essas exatas palavras: não é prudente entrar na água, mesmo morna, senão com o estômago vazio ${ }^{104}$. 0 fût-elle tiède insere uma especificação pouco harmônica com a eloquência distanciada do narrador onisciente. O próprio narrador, aliás, já se preveniu da mescla indevida entre vozes, introduzindo as palavras de Profitendieu por um discurso indireto, indicado pelo estimant que. Ele estimava, não eu. Os discursos foram cuidadosamente cercados para que o leitor não se engane a respeito de quais palavras são propriedade de quais bocas. Por outro lado, o que o senhor Profitendieu possa ter dito não corresponde a uma sentença propriamente sua: a formulação toda se assemelha àquela superstição popular com ampla adesão dos falantes, a uma espécie de albergue do discurso. É o lugar-comum que todos nós corremos o risco, uma hora ou outra, de repetir, como o senhor Profitendieu: não se come e entra na água, mesmo morna, não é prudente fazer isso.

Logo depois, lemos: Après tout, ce n'était peut-être là qu'un préjugé ; mais les préjugés sont les pilotis de la civilisation. Quem fala aqui? Até antes do ponto e vírgula, é possível 
admitir que se trata ainda da voz de Profitendieu. E o que segue, inserido pelo mas? Mas os preconceitos são os pilares da civilização. Poderia, é certo, ser ainda Profitendieu assumindo o clichê da superstição que o acometeu e autojustificando o emprego desse clichê, de modo bastante afetado, como um sustentáculo da vida em comunidade. No entanto, há em os preconceitos são os pilares da civilização um grãozinho de crítica, um gracejo consigo mesmo que a imagem tirânica, esse círculo de seriedade em torno do senhor Profitendieu, não estaria apta a assumir (por vezes, em minhas asserções sobre o senhor Profitendieu, me sinto sua terceira esposa, onisciente e imaginativa). O que está em jogo é um sutil e ao mesmo tempo descarado mecanismo de alternância de vozes, cujo traçado fronteiriço inexiste senão pelo mas. Vejo, todavia, engendrar-se aqui um papel bastante inusitado da partícula de oposição que, ao invés de introduzir apenas uma ideia oposta ou uma concessão (proferida por um mesmo sujeito), introduz também e sobretudo um novo enunciador. É curioso, aliás, notar como os mas habituais (isto é, aqueles que ocasionam o simples trânsito entre predicados de sentidos opostos) transparecem, via de regra, em discursos de personagens ${ }^{105}$. A impropriedade se restringe à articulação do narrador. Dizendo de outro modo, é precisamente o narrador - essa suposição, essa naturalidade do romance - que institui um problema enunciativo em Les Faux-monnayeurs ${ }^{106}$.

\footnotetext{
105 É, de fato, muito mais raro encontrar, no que concerne aos discursos das personagens em Les Fauxmonnayeurs, articulações opositivas que coloquem um problema análogo ao que estou analisando aqui. Os discursos das personagens são muito mais coesos e bem-acabados, por assim dizer. Apenas como ilustração, cito um excerto da carta em que Bernard, ressentido pela descoberta de que é um filho bastardo, se despede do pai, o senhor Profitendieu: "Peut-être estimez-vous que je vous dois la reconnaissance pour avoir été traité par vous comme un de vos enfants; mais d'abord j'ai toujours senti entre eux et moi votre différence d'égards". Les Fauxmonnayeurs, pp. 24-5. Aqui, o mas não introduz senão uma perfeita simetria na relação de oposição com o sentido da oração anterior.

${ }^{106}$ Alain Goulet também atentou para o deslocamento da figura do narrador como um pressuposto do romance em Les Faux-monnayeurs: "multipliant les points de vue, il [Gide] proposait un véritable kaléidoscope de points de vue qui mettait explicitement en question la fonction du narrateur." "Multiplicando os pontos de vista, ele [Gide] propunha um verdadeiro caleidoscópio de pontos-de-vista que colocava explicitamente em questão a função do narrador". Goulet, A. Lire Les Faux-Monnayeurs de Gide. p. 9. Grifo meu.
} 
O alargamento do emprego do mas nesse excerto acende, assim, uma fagulha, que me leva a perguntar: quem fala isso? Mas qualquer que fosse a resposta que eu pudesse encontrar, ela jamais seria tão elucidativa quanto a própria pergunta, que se converte aqui num holofote projetado na ideia de uma presença. Que presença? Presença de quem? Essa curiosidade parece inevitável. Mas já é tarde demais para uma resposta, fomos cegados no instante mesmo em que fixamos diretamente a luz do holofote, e não aquilo que ela iluminava. No mais, a incerteza das interrogações sem resposta - Quem fala isso? Quem está aqui? - só duplica uma primeira incerteza, dada no emprego da conjunção em mais les préjugés sont les pilotis de la civilisation. Isso quer dizer que não estou apta a afirmar nada quanto à identidade desse novo enunciador - ele sequer existe como identidade. Não posso falar dele empregando a terminologia da identidade, mas sim a terminologia do espectro.

É por essa razão que hesito em identificá-lo com a imagem circunscrita do narrador. Quando o narrador fala, temos plena certeza de que é a sua imponente voz que está sendo proferida. O narrador, aqui, parece de todo seguro de si, e se diferencia de maneira esclarecida do senhor Profitendieu através do distanciamento imposto pelo estimant que. $\mathrm{Na}$ última frase do excerto, entretanto, a oscilação entre voz do senhor Profitendieu e voz de espectro é sub-reptícia, clandestina. Um degrau num corredor escuro. A atividade do mas nessa frase é, assim, uma luminosidade de fósforo, um lampejo, uma fagulha que se precipita rumo a uma insólita suspeita, que vem reluzir com teimosia de volta no mundo esférico do narrador: o discurso não va de soi. Uma suspeita impenetrável: o discurso supõe uma presença. O trajeto do romance deixa de ser um correlato do trajeto da vida das personagens para se transformar no próprio trajeto da derrocada do narrador (que não deixa de ser um trajeto crítico, da minha crítica); o itinerário de uma regressiva transição rumo a uma primeira obscuridade, rumo à vida noturna de um primeiro e fantasmagórico enunciador. 
Passemos agora à investigação de um excerto pertencente a Le Prométhée Mal Enchaîné, a reescrita de Gide do mito de Prometeu. Trata-se do seguinte: dois amigos de Prometeu, Damoclès e Coclès, vão juntos assistir ao monólogo estrelado pela figura mitológica e sua águia num teatro de Paris. O trecho seguinte encerra o capítulo dedicado ao espetáculo:

- Messieurs, il faut aimer son aigle, l'aimer pour qu'il devienne beau ; car c'est parce qu'il sera beau que vous devez aimer votre aigle... A présent j'ai fini, Messieurs ; mon aigle va faire la quête ; Messieurs, il faut aimer mon aigle. - Cependant je lance quelques fusées.

Grâce à la diversion pyrotechnique la réunion s'acheva sans trop d'encombre ; mais Damoclès prit froid en sortant de la salle. ${ }^{107}$

Aqui temos contato com duas vozes bem delineadas: a primeira, seguida do travessão, é a voz do próprio Prometeu; a que vem a seguir, depois dos pontos, é a voz do narrador que vem expondo todo o percurso do mito em Paris. Pretendo me deter estritamente nessa segunda voz, que já é problemática o suficiente para a extensão desse trabalho. Grâce à la diversion pyrotechnique la réunion s'acheva sans trop d'encombre ; mais Damoclès prit froid en sortant de la salle: o encadeamento todo dessa frase se vale de dois artifícios retóricos de ligação (grâce à e mais) que, em teoria, constroem uma conexão lógica e causal entre os

107 “Senhores, é preciso amar a vossa águia, amá-la para que ela se torne bela; pois é porque ela será bela que vós deveis amar vossa águia... Agora terminei, senhores; minha águia recolherá as contribuições; Senhores, é preciso amar minha águia. - No entanto, solto alguns fogos de artifício. /

Graças à diversão pirotécnica a reunião terminou sem grandes impedimentos; mas Damoclès tomou friagem saindo da sala". Le Prométhée Mal Enchaîné. pp. 77-8. 
eventos contidos nas orações. Mas não é isso o que vemos operar aqui. Pensemos no que está sendo dito: de que forma soltar fogos de artifício dentro de uma pequena sala de teatro não causa tumulto? Se parafraseio, porém, estritamente o que está na boca do narrador, são os fogos de artifício que evitam o tumulto. É graças à diversão pirotécnica que o espetáculo termina sem grande alvoroço, tanto para os espectadores, quanto, lembremos, para a águia de Prometeu, que está sobrevoando a pequena sala. Dessa forma, o grâce à não articula as orações, mas coloca um problema de articulação no sentido de que a sua utilização não garante o vínculo causal a que habitualmente a expressão se presta. Pelo contrário, ele parece aqui se transformar num insólito operador de contradição. Preparados dessa maneira, o que nós leitores podemos esperar do mais, que vem a seguir?

Grâce à la diversion pyrotechnique la réunion s'acheva sans trop d'encombre ; mais Damoclès prit froid en sortant de la salle. Aparentemente, nada de muito extraordinário: a reunião concluiu-se sem muita confusão, exceto que Damoclès tomou friagem ao sair da sala para a rua, numa noite gelada de Paris. Aqui o mas cumpre uma de suas funções previstas, que é introduzir a ideia de concessão entre as duas orações: não houve confusão, salvo a friagem de Damoclès. Mas será isso mesmo? Parafraseando a oração em minha própria língua, abro espaço a uma proximidade e a um ruído. Releiamos a conjunção à luz dessa proximidade e dando ouvidos a esse ruído.

Partindo da oração la réunion s'acheva sans trop d'encombre, imagino algumas possibilidades de continuação que poderiam mais ou menos prever-se, levando em conta o conector lógico mas. (Embora essa tentativa seja, de minha parte, bastante manipuladora, uma vez que estabilizei como oração de base a sólida la réunion s'acheva sans trop d'encombre, e não a areia movediça introduzida por grâce à la diversion pyrotechnique la réunion s'acheva sans trop d'encombre. Contudo, diante de minha manipulação, façamos um 
esforço para supor que aceitamos entrar no jogo com a ingenuidade daquele que ainda supõe a linearidade causal garantida pelo emprego dos conectores lógicos. É, afinal, uma sistematicidade suposta na língua). O que poderia funcionar como oposição a a reunião terminou sem grandes impedimentos? Talvez, numa formulação genérica, pudéssemos encontrar:

A reunião terminou sem grandes impedimentos, mas houve um pouco de agitação na hora da saída.

Poderíamos ainda ler, dentro de uma perspectiva corporal e descritiva:

A reunião terminou sem grandes impedimentos, mas as pessoas se aglomeravam, coladas umas às outras, tentando sair de uma só vez pela porta estreita.

Ou mesmo:

A reunião terminou sem grandes impedimentos, mas Damoclès foi levado pela multidão e torceu o pé.

Ou ainda, sendo mais catastróficos:

A reunião terminou sem grandes impedimentos, mas a águia, impedida de voar para fora da sala, acabou sendo atingida por um dos fogos.

Nada disso:

A reunião terminou sem grandes impedimentos, mas Damoclès tomou friagem saindo da sala. 
Ora, tomar friagem não se relaciona nem com o tumulto, nem com os fogos de artifício, tampouco com a águia. Nenhum dos fios soltos anteriormente é puxado pelo vínculo concessivo instituído na conjunção. Assistimos, em mais Damoclès pris froid en sortant de la salle, à emergência de um elemento novo, absolutamente lateral em relação a tudo o que fora estabelecido antes. A língua francesa oferece um termo certeiro para descrever, diante disso, a minha impressão: o particípio déboussolée.

Acrescento um dado visual que a simples cópia do excerto nessa página de Word não é capaz de abarcar:

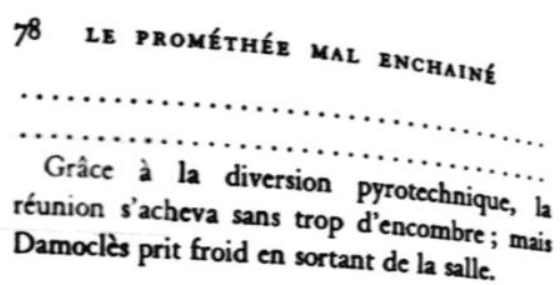

LA MALADIE DE DAMOCLĖS

O trecho, como eu disse, representa o final de um capítulo, que se localiza no alto da página da esquerda do livro, seguido pelo branco dessa mesma página. Na página ao lado, o leitor observa, de cara, o título do capítulo seguinte: "La maladie de Damoclès". Os títulos são 
de fato descritivos, de modo que lemos, nesse capítulo, o desenvolvimento do resfriado de Damoclès. Articulemos esse dado à breve análise que acabei de realizar. Há algo de estranho naquele elemento imprevisto que é introduzido pelo mas. Dentre todos os inesperados desconexos com o que veio anteriormente, é a doença de Damoclès que é estabelecida, justamente aquilo que será desenvolvido no capítulo seguinte. Há algo de uma manipulação descarada, de uma arbitrariedade de encadeamento em relação à qual nós, leitores, costumamos ser especialmente malevolentes; o que leva a pensar que estamos de tal modo aferrados ao mundo fechado e coerente do romance, que ele funda ainda nosso horizonte de expectativa (embora o título do livro seja um alerta cristalino: O Prometeu mal encadeado). Todavia, tomando-o ou não com malevolência, devemos admitir que um encadeamento arbitrário dos fatos é ainda um encadeamento. A presença como que inapropriada do mas não decreta que entre as orações a desconexão seja absoluta, mas simplesmente propõe que, entre elas, haja uma conexão de outra ordem. A partícula de oposição serve menos a uma real oposição entre os significados do que ao próprio mal encadeamento da narrativa. Ela opera como que a serviço de um deus ex machina.

Mas o que é um deus ex machina? Nas encenações antigas, todos os fios soltos durante a peça eram amarrados pela representação de um deus cuja estátua descia literalmente de uma maquinaria, um deus surpreendente e apaziguador. Um deus que vem do alto e não do horizonte; que vem, portanto, de fora. A expressão sofreu historicamente um esquecimento - por uma questão de sobrevivência, uma vez que não há representação que dê conta de um deus cristão descendo em uma máquina - e hoje indica figurativamente qualquer solução inesperada. Mas no seio da ideia de uma solução inesperada, resistindo à abstração metafórica, se mantém a concretude do deus descendo da máquina, ou ao menos a concretude de seu movimento: o nosso deus ex machina significa uma vontade estranha à 
esfericidade de cada mundo ficcional, à lógica própria que cada mundo ficcional estabelece (nos termos de Aristóteles, à sua verossimilhança). O nosso deus ex machina é, assim, uma presença exterior.

Voltemos ao livro: há em Le Prométhée Mal Enchaîné algo semelhante ao impulso de Les Faux monnayeurs e também de Les Caves du Vatican ${ }^{108}$ de esgotar, nadando para além das balizas de narração, a potência contida em cada empreitada de narrador. Um impulso de partir para todos os lados, de explorar, não só horizontal, mas vertical e diagonalmente, a amplitude da narração ${ }^{109}$. Sempre encontro em Gide essa vontade imatura de experimentar tudo. No caso dos livros aqui mencionados, essa exploração, operada no terreno da narração tradicional, só pode ocorrer sob a forma de um deus ex machina. Ela remeterá inevitavelmente a uma presença que vem de fora, reluzindo acima de tudo a aleatoriedade das associações de um alguém ${ }^{110}$. O enunciador não está mais coberto dos pés à cabeça pela coerência da narração, mas, lentamente, conector por conector, vai se despindo e se exibindo para o leitor, ainda que - num entendimento total do jogo de sedução - seu strip-tease nunca seja um percurso completo. Isso significa que a narração, aqui, não é mais um enorme cobertor - como, de modo geral, para Stendhal, como para Balzac - mas simplesmente um véu. Por maior que seja a discrepância entre o emprego do mas no excerto de Le Prométhée Mal Enchaîné e o mas de Les Faux monnayeurs, o rastro, o lampejo, é ainda o mesmo: uma presença velada, um espectro.

\footnotetext{
${ }^{108}$ São livros com datas de publicação muito próximas: Le Prométhée Mal Enchaîné e Les Faux-monnayeurs são de 1925, e Les Caves du Vatican, de 1922.

109 "O que me atrairá para um novo livro não são tanto as novas figuras quanto uma nova maneira de as apresentar. Este se terminará bruscamente, não por esgotamento do assunto, que deve dar a impressão de ser inesgotável, mas, ao contrário, por seu alargamento e por uma espécie de evasão de seu contorno. Ele não deve se fechar, mas espalhar-se, desfazer-se". Diário dos moedeiros falsos, p. 106.

${ }^{110}$ Lembro-me de Benveniste em "Structure de la langue et structure de la société", dizendo que chacun parle à partir de soi [cada um fala a partir de si]. In : PLG II. p. 98.
} 


\section{A posição legítima}

As escritas em primeira pessoa, em Gide, ofereciam - ainda que num espaço acidentado - um controle da preponderância do je que, de algum modo, parece perder-se no emprego da terceira pessoa. No primeiro caso, embora houvesse uma sutil desestabilização da linearidade, embora houvesse rompimentos, erosões, terrenos irregulares e montanhosos, nos quais não se caminha com nenhuma tranquilidade, embora isso tornasse a trajetória irremediavelmente traiçoeira, tudo, nessa primeira pessoa - todas as montanhas, vales e erosões - voltava-se servilmente para um je. Alain Goulet chama a atenção para essa espécie de campo magnético do je que Gide cria em seu primeiro pseudônimo, André Walter, identificando-o, no entanto, a uma região desértica: no início, o mundo de André Walter é estranhamente deserto, e seus Cahiers se organizam como um complexo jogo de espelhos que multiplicam sua imagem ${ }^{111}$. Esse jogo de espelhos que multiplica o je vincula-se, a meu ver, à enunciação produzida pelo je, ao posicionamento implicado na singularidade e na evasão do pronome, mais do que a uma imagem autoral que tem origem no pseudônimo. Mas a preponderância do complexo jogo de espelhos traz um dado importante: quando um je fala, em nenhum momento ele precisa sequer pensar em se preocupar sobre estar ou não ali, ocupar ou não aquele espaço: o espaço é o seu próprio império, o espaço é ele mesmo, as contradições são inclusive a ostentação do seu si mesmo. Todas as coordenadas se organizam segundo a sua posição suprema, confusa e controladora.

${ }^{111}$ GOULET, A. “Gide em Pauta”, p. 202. 
Já em narrativas que são enunciadas por algum tipo de terceira pessoa, como Les FauxMonnayeurs e Le Prométhée Mal Enchaîné, um problema de outra ordem acomete a enunciação, que parece ser o seguinte: como ocupar a escrita - alguém, afinal, está ocupandoa, emergindo enquanto escreve, e não pode ser de outro modo - como ocupar a escrita dizendo tudo o que se deve dizer a partir de uma boca terceirizada, uma boca impessoal? Como entrar na terceira pessoa que é, nas palavras de Benveniste, uma não-pessoa? Como lidar com a minha presença, junto da presença deste outro, que nem sei quem é? Todas essas dúvidas transparecem, como um palimpsesto, na leitura das adversativas presentes na narração em terceira pessoa.

As adversativas cumprem, então, um papel fundamental em minha exploração. $\mathrm{Na}$ primeira parte, elas indicavam a estrutura do pensamento dos jes: os mas associavam num emaranhado frasal a existência dispersa e caótica desses jes. Já aqui, a atenção detida nas adversativas ilumina o fato de que, na indecisão sobre o posicionamento enunciativo, na emigração desse posicionamento para fora do je, em sua suposta fusão com o il, o mas passa a designar espaços de ruptura, de lapso. O que o antecede pode até estabelecer uma área de terra firme (como nos excertos analisados: isso talvez não fosse mais do que um preconceito, a reunião terminou sem grandes impedimentos), mas o que vem depois do conector (mas os preconceitos são os pilares da civilização, mas Damoclès pegou um resfriado saindo da sala) é já composto por uma outra matéria, é já a voz espectral de um enunciador desconhecido. 0 mas é aqui uma fronteira física: num movimento de passagem, deixa-se a terra firme do narrador rumo a um destino novo - como quando um mergulhador, do alto de uma falésia, cai de cabeça no mar. 
Espectro, rastro, presença. Esses termos empregados com frequência aqui assumem contornos vagos, pouco explícitos. Essa indefinição me leva até uma ideia de Rancière, presente no texto "A literatura impensável":

Aquilo que virá a ser recoberto pelo nome "indeterminado" de literatura poderia então ser o redesdobramento daquilo que aqui está fechado, o conjunto aberto e sem lei das aventuras da letra com falta de um corpo, onde a delimitação dos discursos não para de se apagar, voltando a tomar figura sem cessar, onde qualquer distribuição legítima das posições de enunciação desaparece na comunidade sem contornos dos seres falantes. $O$ ser da literatura seria o ser da língua onde esta se furta às ordenações que dão aos corpos vozes próprias para colocá-los em seu lugar e em sua função: uma perturbação na língua análoga à perturbação democrática dos corpos quando só a contingência igualitária os põe juntos. ${ }^{112}$

Fica claro que promovi aqui um salto das leituras dos dois excertos de Gide para aquilo que virá a ser recoberto pelo nome "indeterminado" de literatura: um conjunto aberto e sem lei das aventuras da letra com falta de um corpo. Três coisas perdem sua constância e seu predomínio nessa aventura da letra: a fronteira dos discursos, as posições legítimas de enunciação, o contorno dos seres falantes. Essas três avalanches se produzem a partir do que Rancière identifica como o ser da literatura. Mas qual a necessidade em falar de um ser da literatura, num contexto em que o que está em jogo é, não a identificação de uma propriedade intrínseca - que poderíamos associar ao ser -, mas o despovoamento das identidades, a abertura de fronteiras, a provisoriedade dos seres falantes? Creio que essa pergunta aclare, por sua vez, a razão pela qual esse excerto de Rancière vem marcar o término das falésias, o seu limite amplo e generalizante, quando como, de uma trilha estreita e abafada, depara-se

${ }^{112}$ Rancière, J. “A literatura impensável”, In: Políticas da escrita. pp. 28-9. 
de uma hora para outra com o mar. Essa generalização rumo ao ser da literatura é o olhar que lanço para a água, para uma amplitude que surge de uma hora para outra, enquanto ela projeta sua vaga interrogação de volta para mim, um reflexo.

A ideia de um ser implica, é evidente, muitas outras. Ela carrega consigo uma tradição filosófica, cuja relação modesta que me cabe fazer no âmbito deste texto é com a terminologia da identidade a que me referi antes. O ser é uma raiz entranhada em nosso pensamento, mas o seu reinado se relativiza se nos lembramos, com Benveniste, de que é apenas em determinadas línguas que existe um verbo ser, cujo legado, cuja normalidade promovem um esquecimento bem localizado do fato de que esse verbo não existe para todos os locutores do mundo ${ }^{113}$. Todo o problema de Gide (devo ser alguma coisa, e me obrigam a ser uma coisa a despeito de outra, sempre excluindo a outra coisa que também sou a despeito de tudo, mas vou me virando) se concentra na existência por vezes desafortunada desse verbo, tudo o que ele escreve é um desdobramento infinito desse vou me virando. As leituras que fiz da partícula mas tomam parte nesse desdobramento.

A referência de Rancière ao ser da literatura não parece distante desse vou me virando. Não se trata de um ser que incorpore realmente a unicidade, a uniformidade do ser. Não parece haver aqui vínculo algum com a terminologia da identidade. Para Rancière, não se pode

\footnotetext{
113 « II s'ensuit que ce qu'Aristote nous donne pour un tableau de conditions générales et permanentes n'est que la projection conceptuelle d'un état linguistique donné. On peut même étendre cette remarque. Au-delà des termes aristotéliciens, au-dessous de cette catégorisation, se déploie la notion d' " être " qui enveloppe tout. Sans être un prédicat lui-même, l' " être " est la condition de tous les prédicats. (...) Or, ici encore, c'est une propriété linguistique très spécifique que ce concept reflète. Le grec non seulement possède un verbe " être » (ce qui n'est nullement une nécessité de toute langue), mais il a fait de ce verbe des emplois tout à fait singuliers ". "Segue-se que aquilo que Aristóteles apresenta como um quadro de condições gerais e permanentes é apenas a projeção conceitual de um dado estado linguístico. Podemos inclusive ampliar essa observação. Para além dos termos aristotélicos, desdobra-se, subjacente a essa categorização, a noção de "ser" que recobre tudo. Sem ser ele próprio um predicado, o "ser" é a condição de todos os predicados. (...) Mas ainda aqui é uma propriedade linguística muito específica que o conceito reflete. O grego não somente possui um verbo "ser" (o que não é de forma alguma uma necessidade para qualquer língua), como também promoveu empregos desse verbo que são absolutamente singulares". Benveniste, E. "Catégories de pensée et catégories de langue ", In: PLG I. pp. 70-1.
} 
encontrar uma propriedade inerente à literatura, uma vez que o seu próprio é precisamente não ter próprio algum; de modo que não pode haver um ser da literatura, uma raiz da literatura, a sua essência. Esse ser é apenas um incansável desordenamento, um potencial de desordenamento plantado nas palavras. E um tal potencial não se limita apenas ao discurso (o discurso nunca é apenas o discurso), ele implica também uma redistribuição dos corpos e de seus respectivos postos, caracteres, habitações - um desordenamento plantado na ideia mesma de um ser.

Mas será que a literatura não se afirma como tal onde essa posição ideal do narrador se desfaz: quando o "eu" ou o "nós" que começa a narração logo a abandona (Madame Bovary); quando o "eu" não se apresenta e nos deixa na indecisão quanto às partes do autor, do narrador e do personagem (A la recherche du temps perdu); quando ele conta até a história que ele não pôde saber (Tristam Shandy) ou que já não pode mais contar (Memórias póstumas de Brás Cubas). ${ }^{114}$

Não há a serenidade, para a literatura, de uma posição ideal ou mesmo de uma voz própria, cuja raiz remontaria a um sujeito determinado. Assim, esse estranho ser da literatura, até onde posso alcançar na obscuridade das palavras de Rancière - o que me resta efetivamente é apenas traduzi-lo com meu próprio pequeno artesanato de palavras, que é acima de tudo Gide -, esse estranho ser da literatura não é nada ocasional: trata-se de uma expressão em que o segundo termo implode o primeiro, esfiapa a sua identidade fundante, o seu imperiozinho irremovível e fragilizado. Esse ser não é uma circunscrição, mas um espectro, um rastro, ou ainda um espaço, uma ampla região onde qualquer distribuição legítima das posições de enunciação desaparece na comunidade sem contornos dos seres falantes. $A$

\footnotetext{
114 “A literatura impensável”, pp. 38-9.
} 
questão da ficção é, antes de tudo, uma questão de distribuição de lugares ${ }^{115}$, indica Rancière num outro texto.

Resta dizer uma coisa. Enquanto que o processo mais comum a que o verbo ser se submete continua sendo a subjetivação (o ser), o emprego que Rancière faz dele na expressão ser da literatura aproxima-se da movência e do vazio constitutivos da pronominalização - que é o constante operador de fuga do qual Gide se vale. Esse procedimento lança uma investida contra o anseio desesperado de vinculação do pronome eu, que assinala posições temporárias e intercambiáveis de sujeito, com o verbo ser substantivado (o eu é aqui o narrador, etc.), anseio que suplanta, por sua vez, a origem efetivamente pronominal do eu.

Muitas outras palavras atravessam a centralidade do verbo ser, atravessam, simplesmente, como um trem atravessa uma cidade, atravessam-no sem necessariamente alojar-se nele.

${ }^{115}$ Rancière, J. A partilha do sensível, p. 17. 
Ce

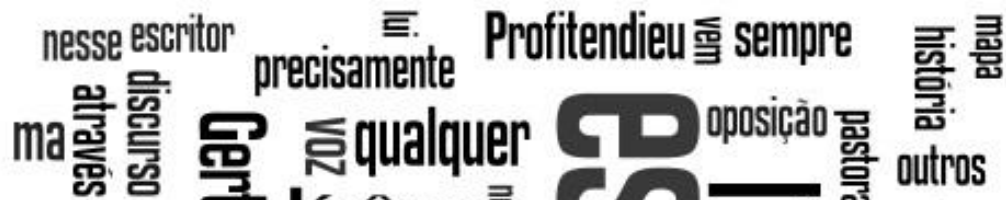

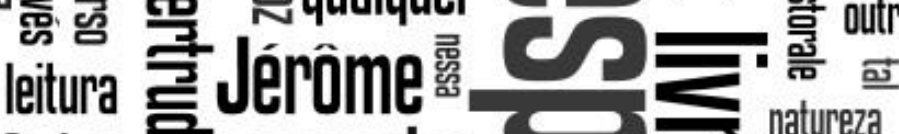
André 高 nannadon natureza

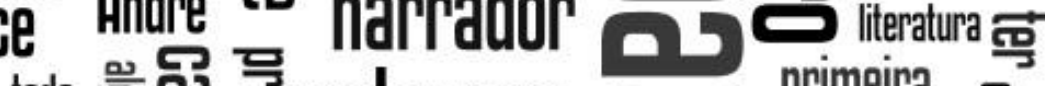

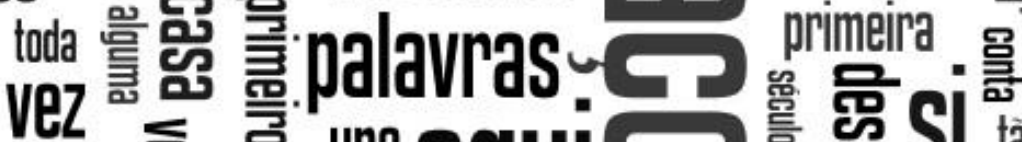
올돌

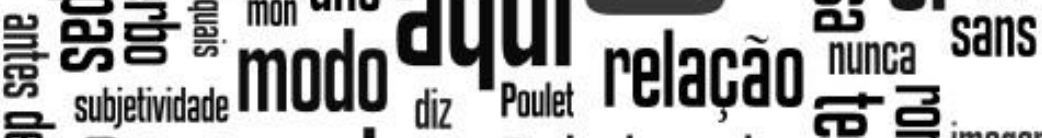

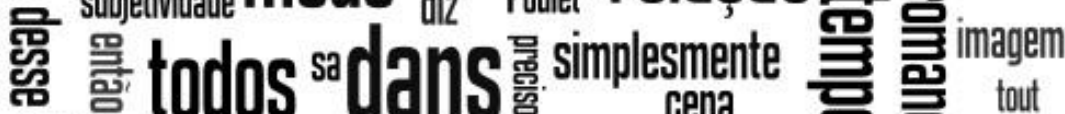
色

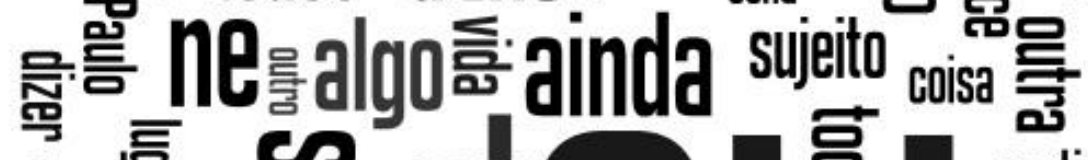
algum 营 음

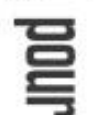

le믇몬

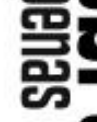

cada corto dire

号兽 textopresença 畹 cuja 言

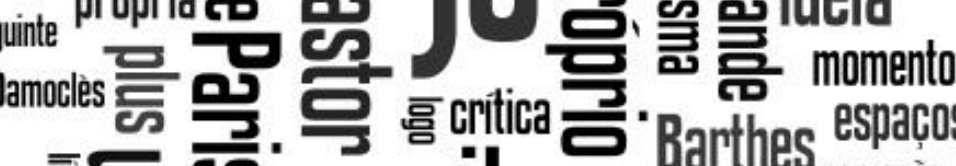

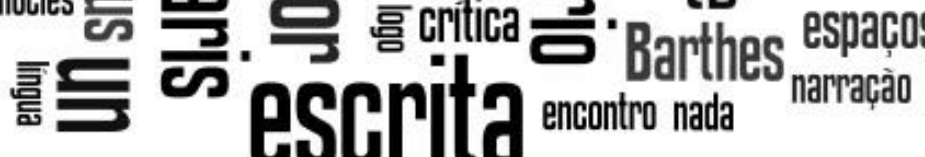

partir

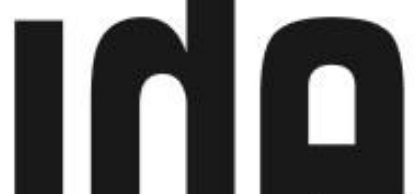


Eu estou aqui 


\section{Mapa}

Ao longo do período do mestrado, tive a oportunidade de transitar por certos projetos, advindos da geografia e das artes visuais consideradas de um ponto de vista menos especializado e fronteiriço, que acolhem inteiramente a ideia de uma geografia pessoal, de um mapa cuja representação não seja dada de antemão pela convenção e pela oficialidade. A imagem exemplar dessa convenção se encontra na chamada projeção de Mercator ${ }^{116}$, disponível para consulta no site do Instituto Brasileiro de Geografia e Estatística ${ }^{117}$ (IBGE):

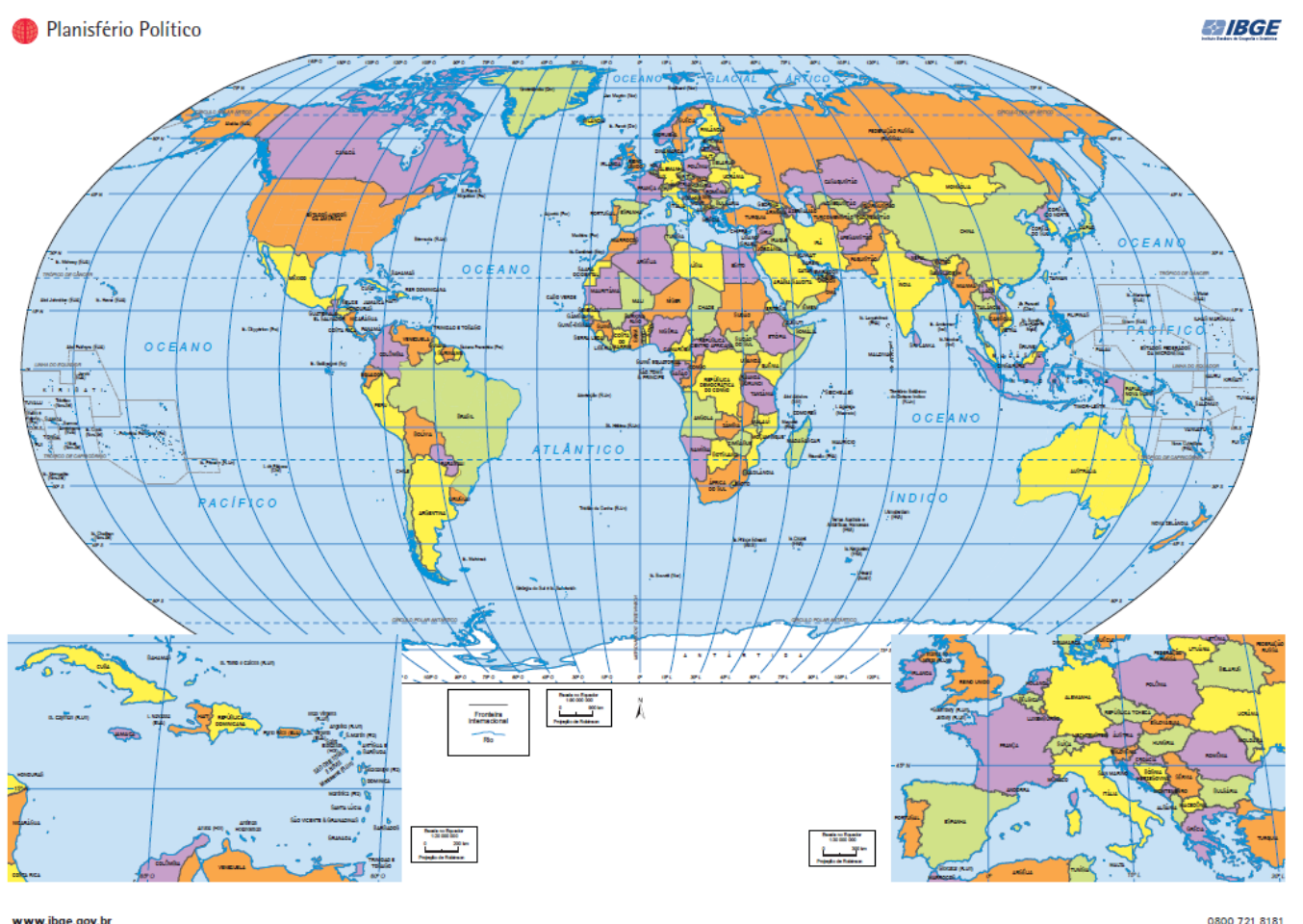

\footnotetext{
${ }^{116}$ Agradeço à minha orientadora Verónica Galíndez por ter chamado minha atenção para esse nome.

117 http://atlasescolar.ibge.gov.br/mapas-atlas/mapas-do-mundo/divisoes-politicas-e-regionais Acesso em: 14/11/2014.
} 
Trata-se de uma representação oficial divulgada pela principal instituição de geografia do país, amplamente difundida nos atlas escolares e nas representações midiáticas, que normaliza a forma através da qual apreendemos o globo terrestre. Essa normalização decorre de um apagamento das marcas de uma enunciação que localizaria o próprio mapa, que tornaria possível o mapeamento do próprio mapa. É raro dirigir qualquer ênfase ao fato de que Mercator é o sobrenome do geógrafo que propôs, no século XVI, essa projeção cartográfica: o nome, sua localização e sua possível narrativa são inteiramente absorvidos pela imagem que se fixa, desaparecendo em meio à amplitude da padronização. Mas nessa rápida incursão pela cartografia, pude também me dar conta de que hoje levanta-se um proeminente movimento em sentido contrário, alavancado pela emergência de projetos que se servem de mapas cuja representação se constrói junto da experiência dos habitantes de determinado lugar. Mapas que, eles próprios, são capazes de dizer: eu estou aqui.

Posso citar como exemplo o projeto da pesquisadora Karen O’Rourke, intitulado A Map larger than the territory ${ }^{118}$. Trata-se de um site no qual mapas de cidades ficam disponíveis para que as pessoas adicionem suas trajetórias cotidianas ou inusitadas correspondentes àquele lugar; e, para isso, elas podem se servir de textos, imagens ou sons:

${ }^{118}$ http://www.mapterritory.com/?lang=en. Acesso em: 14/11/2014. 


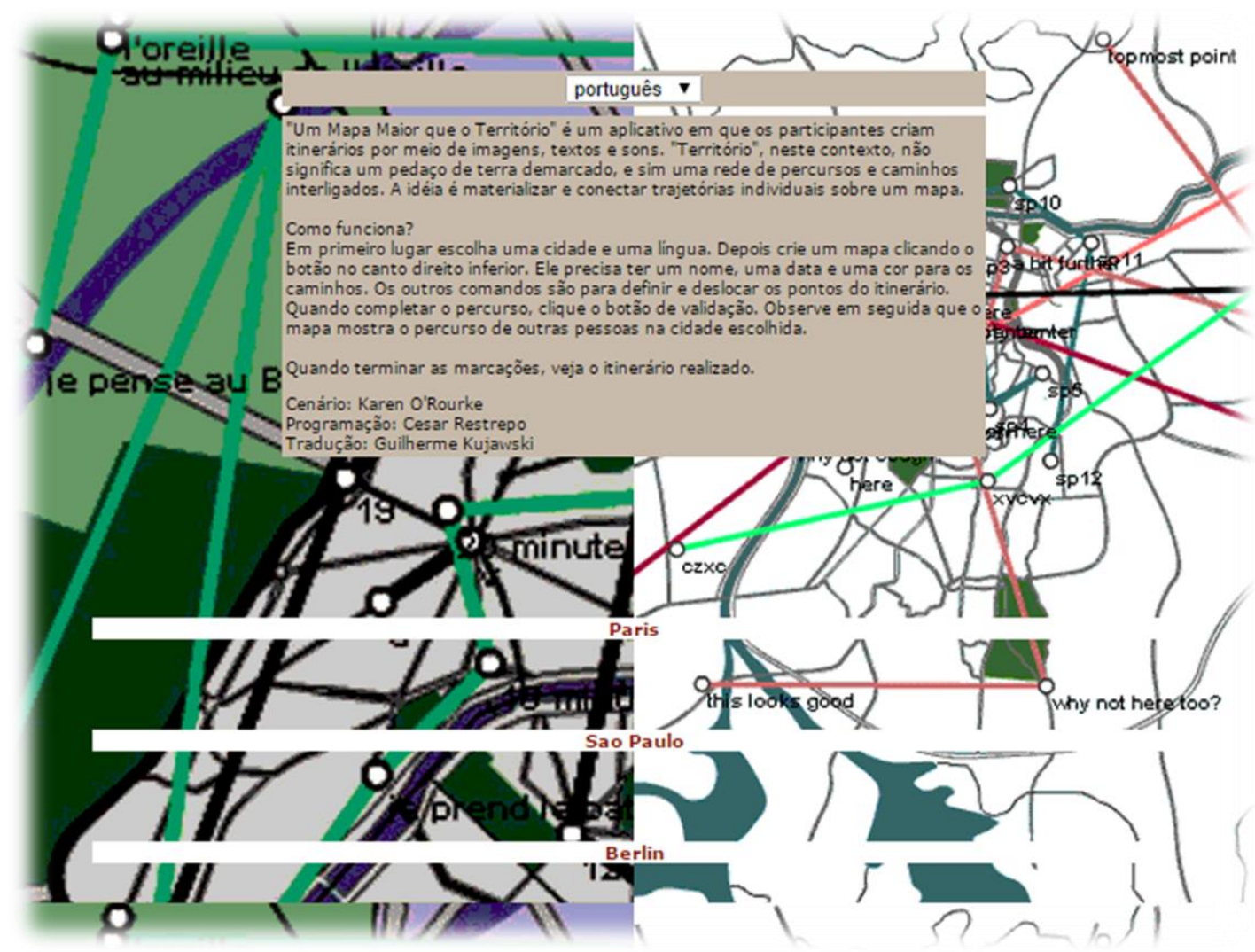

Território, nesse contexto, não significa um pedaço de terra demarcado, e sim uma rede de percursos e caminhos interligados. A recusa pela demarcação prévia acompanha uma magnitude do percurso, do caminho que cada um realiza por conta própria, e que é, ele também, digno de se marcar num mapa; ele é, mais do que tudo, fundamental para a concepção de um mapa.

Ademais, esse não é o único projeto a ser citado. Há o livro da já citada curadora de arte e pesquisadora Katharine Harmon, intitulado You are here: personal geographies and other maps of the imagination ${ }^{119}$, que reúne representações cartográficas pessoais, nas quais vemos marcas evidentes de seus enunciadores (ou seja, mapas em que há o mínimo possível a pretensão à universalização das perspectivas espaciais neles traçadas):

\footnotetext{
119 Harmon, K. You are here: personal geographies and other maps of the imagination. Princeton: Princeton Architectural Press, 2003.
} 


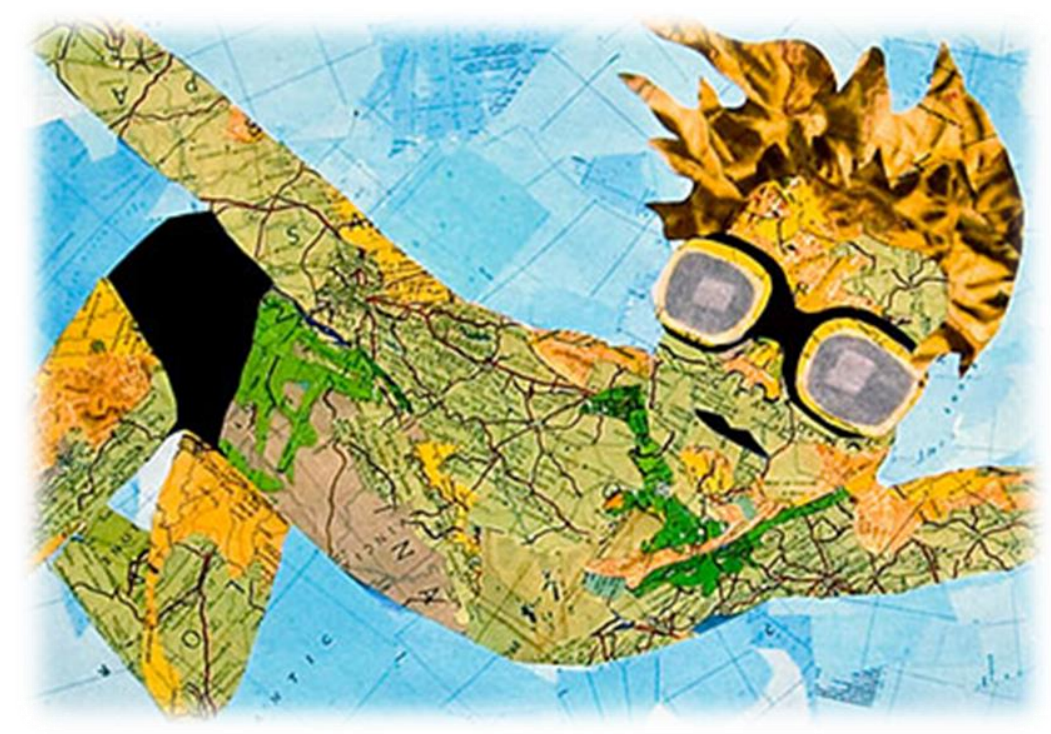

Há ainda o projeto do Institute of Infinitely Small Things, intitulado The city formely known as Cambridge, o qual propôs uma enquete virtual com os moradores de Cambridge para que eles renomeassem as ruas da cidade ${ }^{120}$.

A proposta de uma geografia pessoal tem todo o interesse, tem toda a pertinência para o que eu disse aqui até agora. Ela nos lembra de que aquilo que se cristaliza enunciativamente em torno de um espaço demarcado pode ser retomado, habitado uma nova vez; pode até haver, em determinados casos, um acampamento do discurso, um alojamento passageiro, 0 que pressupõe certos operadores de fuga do discurso cristalizado, por vezes mínimos operadores de evasão. A demarcação prévia de todo modo existe, mas poderíamos concebêla tal como um grupo de pessoas que decide realizar uma ocupação clandestina. Os ocupantes não deixarão de partilhar, em sua empreitada, as exatas mesmas paredes, as exatas mesmas salas daqueles a que um dia pertenceu oficialmente a casa, que ali dormiram, permaneceram, pensaram em coisas e as deixaram pairando. Mas existirá com toda certeza, a partir da

120 Disponível em: http://www.ikatun.org/kanarinka/the-city-formerly-known-as-cambridge/ Acesso em: $14 / 11 / 2014$. 
mudança, uma minuciosa atividade de habitação que se exerce no alojamento passageiro. Em outras palavras, constitui-se ali um espaço propriamente dito, fruto da relação da pessoa com a localidade, e que é ao mesmo tempo uma coisa compartilhada e uma coisa até muito singular.

This book is how we have chosen to travel visually across and inside the world. We could have chosen many other routes, other themes, other subjects ${ }^{121}$. Esses dizeres do epílogo de um Atlas recentemente publicado me fizeram pensar que a ideia do Atlas nunca foi refratária a uma geografia pessoal. Os três autores desse livro encerram a sua jornada dizendo: poderíamos ter escolhido outros caminhos, outros temas, outros assuntos. Um atlas nunca é um todo, mas tão somente, tão exclusivamente uma escolha.

Num outro documentário do já citado cineasta Werner Herzog, Gasherbrum, a montanha luminosa, Herzog acompanha uma inédita e arriscada expedição que o montanhista Reinhold Messner decide, junto de seu colega Hans Kammerlander, empreender nos dois picos Gasherbrum, localizados nas cordilheiras do Himalaia. A altura dos picos ultrapassa 8000 metros, e os montanhistas estão determinados a escalá-los sem acampamento prolongado (é comum, quando se escala picos muito altos, que acampamentos

${ }^{121}$ Losowsky, A.; Ehmann, S. et al. "Epilog”, In: Around the world. The atlas for today. 
fixos sejam instalados ao longo do trajeto, como uma referência, mas Messner recusou essa precaução). Para a filmagem, Herzog monta uma barraca na beira da montanha congelada, entrevistando os escaladores na saída e também cerca de dez dias depois, no instante de seu retorno.

É precisamente nesse momento que os três ouvem com atenção, ao pé dos vales Gasherbrum, os seguintes dizeres: vocês têm dimensão do que é estar aqui, no vale Gasherbrum, nesse remoto conjunto de picos numa região remota do Himalaia depois de Reinhold Messner ter subido, junto de seu companheiro Hans Kammerlander, os dois picos Gasherbrum e de Werner Herzog, esse paciente documentarista, ter esperado durante quase duas semanas num acampamento à beira da montanha? Sugeriram-me, certa vez, que seria oportuno, ao fim de uma escalada ou de uma trajetória, enunciar o lugar que se ocupa naquele momento, mas a verdade é que eu não saberia bem explicar, apenas desejaria estar aqui com vocês, no vale Gasherbrum, mesmo que após uma escalada só imaginária, uma escalada da escrita, rumo ao grande escritor do século XX André Gide, cujas dificuldades nunca vão chegar sequer aos pés da inigualável e extrema expedição de Messner e Kammerlander, ou mesmo da paciência inigualável do documentarista Herzog, mas o que me faz desejar estar aqui é a inigualável impulsão que se sente e que se divide no auge do desejo de aventura. Então eu queria perguntar a vocês se, depois disso tudo, vocês que atravessaram um trajeto extraordinário, vocês poderiam explicar isso para mim, para que eu possa ter em vocês um ponto de referência, uma espécie de precaução ou de acampamento para as palavras: vocês têm a dimensão exata de onde estão, ou a consciência exata dos lugares por onde passaram e também daqueles rumo aos quais pretendem ir? 
Reinhold Messner - Às vezes eu quero parar de escalar montanhas e imaginar que eu caminho durante dezenas de anos, talvez para sempre, com os yaks, alguns carregadores, indo de um vale do Himalaia ao outro, através dos desertos, dos bosques, sem ir a parte alguma, sem olhar para trás, sem nem mesmo olhar para a frente, enquanto continuo caminhando até o extremo do mundo.

Herzog - Estranho, tenho precisamente o mesmo sonho. Queria ter um cachorro, um husky com duas bolsas de couro, e caminhar até ter passado por todos os lugares.

Messner - Sim, isso é muito interessante, e imagino que, cada vez mais, nos próximos anos, cedo ou tarde na minha vida, não olharei mais para trás. Como se não tivesse mais nada, como se não precisasse de mais nada e apenas caminhasse até o fim do mundo. Não sei se é redondo ou plano, para mim o mundo nunca acaba. Mas em certo momento vou parar. Deve ser, provavelmente, o momento em que minha vida chega ao fim. E o mundo continuará o mesmo. Cada um de nós poderá seguir os passos do outro.

Herzog - Fico feliz só de imaginar.

Messner - Escalar montanhas já não é tão importante pra mim. Especialmente a escalada. 0 importante é caminhar, caminhar mais. ${ }^{122}$

122 Excerto de Gasherbrum, a montanha luminosa. 41'34 a 43'21. Disponível em: https://www.youtube.com/watch?v=Ky9eprVWzll Acesso em: 22/09/2012. 


\section{Cordilheiras e falésias, cordilheiras e falésias}

As cordilheiras e falésias, em Gide, não podem encontrar repouso numa representação gráfica. Nisso reside uma espécie de contradição: embora este atlas proponha dimensionar e até mesmo localizar determinadas regiões de Gide, as imagens dos espaços que se aglomeram aqui não são nada além de imagens providas de um corpo apenas provisório, uma névoa ou um precipício. Não há um contorno definido para as regiões, poder-se-ia inclusive colocar a pergunta sobre a existência dessas regiões. Elas são móveis, não há mapas - ou só há uma possibilidade parcial de mapeamento, cuja finitude é, tal como uma falésia, o encontro com o oceano. Aparece de repente que, em Gide, o espaço, tomado em sua forma mais geral e mais nua, não existe.

O problema do espaço, nesta dissertação - considero isso uma espécie de sintoma -, não se centra na descrição, uma materialidade que poderia ser contornada, catalogada, circunscrita. Com exceção, é claro, da análise das descrições de La Porte étroite, as quais, no entanto, apenas desembocam na verdadeira espacialidade de palavras (quarto do monólogo confessional, jardim das conversas secretas e importantes) da qual se constitui o livro. A espacialidade aqui não se petrifica no critério da descrição espacial, porque o espaço enunciativo fundado em Gide só ambiciona novos e novos destinos, contrariando-se de imediato com qualquer gênero de quietude ou de vida sedentária. A enunciação alojada no pronome é uma instância a cada vez renovada, que pula de casa em casa, de identidade em identidade.

II n'y avait, du temps de mon père, que peu de sentiers tracés, et d'être si difficilement pénétrables, ces bois me paraissaient plus vastes. Je 
fus bien désolé le jour où maman, tout en me permettant de m'y aventurer, me montra sur une carte du cadastre leur limite, et qu'au-délà, les prés et les champs recommençaient. Je ne sais plus trop ce que j'imaginais au-delà des bois ; et peut-être que je n'imaginais rien ; mais, si j'avais imaginé quelque chose, j'aurais voulu pouvoir l'imaginer différent. De connaître leur dimension, leur limite, diminua pour moi leur attrait ; car je me sentais à cet âge moins de goût pour la contemplation que pour l'aventure, et prétendais trouver partout de l'inconnu. ${ }^{123}$

Preservemos esse traço de juventude de Gide; as imagens são unicamente uma forma de encontrar-se provisoriamente, de diluir-se.

123 "No tempo de meu pai, só havia algumas poucas trilhas demarcadas e, por serem tão dificilmente penetráveis, esses bosques me pareciam mais amplos. Fiquei desconsolado o dia em que mamãe, permitindo que eu me aventurasse por ali, me mostrou os seus limites num mapa, e que, depois dali, as redondezas e os campos recomeçavam. Não sei mais muito bem o que eu imaginava para além dos bosques; e talvez eu não imaginasse nada; mas, se eu tivesse podido imaginar alguma coisa, eu gostaria de poder imaginá-la de forma diferente. Conhecer as suas dimensões, os seus limites, diminuía para mim o seu atrativo; pois eu sentia, nessa idade, menos gosto pela contemplação do que pela aventura, e pretendia encontrar em toda parte o desconhecido". Gide, A. Si le grain ne meurt. p. 72. 


\section{Gide foi um grande escritor do século XX}

Procurando fotos de Gide no Google, me vejo preservando um fascínio pelo homem Gide, que reconheci desde que li pela primeira vez o ensaio "Notas sobre André Gide e seu Diário", de Barthes (também ele seduzido pela figura humana: duvido que o Diário desperte grande interesse se a leitura da obra não tiver previamente despertado curiosidade sobre o homem), mas o que me interessa em Gide não é necessariamente a imagem das fotos (nem um pouco), nem as obras que leio. O que me fascina é o fantasma, sem situação específica, desaparecido entre o homem e as palavras, impróprio tanto com relação ao homem, quanto com relação às suas palavras.

Não se trata exatamente de uma identificação com esse espectro, mas da projeção de uma pessoa apaixonada, pendurada no amor desnivelado e em algumas horas até infantil.

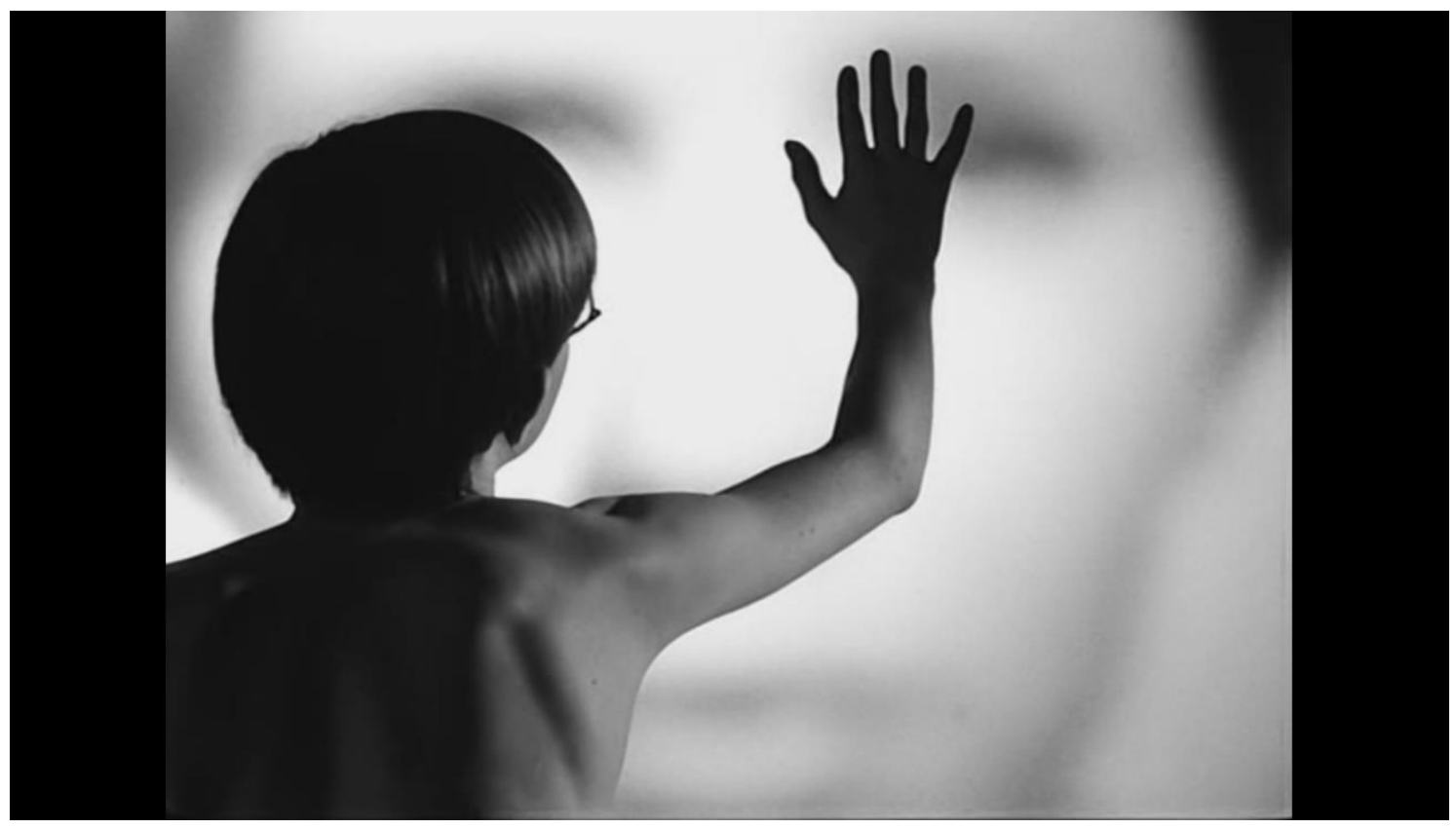

Fronteiras: uma fusão impossibilitada entre um sujeito, um verbo de ligação e o seu predicado. 


\section{Todos os espaços}

Seria uma loucura, sem dúvida, agrupar num só romance tudo o que a vida me ensina e me apresenta. Por mais denso que eu pretenda esse livro, não posso incluir tudo nele ${ }^{124}$. Gide sempre alimenta um ressentimento em relação àquilo que sobra de sua escrita. Percebo-o através da profusão de comentários realizados no interior de sua própria obra. Gide utiliza de bom grado o espaço do prefácio, do ensaio, ou mesmo a generosidade da autobiografia, que Ihe oferece grande liberdade para analisar, explicar-se. Sem contar o Diário, que é simplesmente a assiduidade do comentário. A natureza desse comentário acaba recaindo, com frequência, sobre o próprio ato de escrever. Podemos observá-lo, por exemplo, nas justificativas levantadas contra a expectativa do público, a qual Gide prevê antes mesmo de publicar o livro, em relação ao seu posicionamento autoral sobre L'Immoraliste:

Je n'ai voulu faire en ce livre non plus acte d'accusation qu'apologie, et me suis gardé de juger. Le public ne pardonne plus aujourd'hui que l'auteur, après l'action qu'il peint, ne se déclare pas pour ou contre ; (...) Je n'ai cherché de rien prouver, mais de bien peindre et d'éclairer bien ma peinture. ${ }^{125}$

É o mesmo ímpeto contido na resposta que Gide elabora a Roger Martin du Gard, defendendo-se das acusações contra um estilo demasiado elíptico, ao final da segunda parte de Si le grain ne meurt:

\footnotetext{
${ }^{124}$ Diário dos moedeiros falsos. p. 17.

125 "Não quis fazer nesse livro nem ato de acusação nem de apologia, e me poupei de julgar. Hoje o público não perdoa mais que o autor, depois da ação que ele pinta, não se declare a favor ou contra; (...) Não procurei provar nada, mas pintar de modo nítido e de aclarar bem minha pintura." L'Immoraliste. pp. 10-11.
} 
Roger Martin du Gard, à qui je donne à lire ces Mémoires, leur reproche de ne jamais dire assez, et de laisser le lecteur sur sa soif. Mon intention pourtant a toujours été de tout dire. Mais il est un degré dans la confidence que l'on ne peut dépasser sans artifice, sans se forcer; et je cherche surtout le naturel. (...) Tout est toujours plus compliqué qu'on ne le dit. Peut-être même approche-t-on de plus près la vérité dans le roman. ${ }^{126}$

E, ainda, nesse excerto do Journal:

Seja qual for o livro que escrevo, nunca a ele me dou por inteiro, e o tema que me reclama com mais insistência logo depois desenvolve-se, entretanto, na outra extremidade de mim mesmo. ${ }^{127}$

Por maior que seja a diversidade que os textos acima apresentem, todos eles concernem a uma mesma natureza de autojustificativa, de réplica, de transbordamento do próprio texto. A uma necessidade de dizer coisas como que paratextualmente.

Em Gide, as reescrituras dos mitos, assim como a máscara do romance tradicional, são grandes articulações opositivas. É como se, por trás de tudo, ele dissesse: existem essas personagens, Teseu e Prometeu, escritos por Racine, Ésquilo, Hesíodo, existem esses narradores de Balzac e Stendhal, mas existe algo que vai extraordinariamente além, uma sobra, que eu, de modo incansável, escrevo mesmo assim. Esses personagens representam

\footnotetext{
126 "Roger Martin du Gard, a quem dou a ler essas Memórias, Ihes reprova o fato de não dizerem jamais o bastante, e de deixarem o leitor ávido por mais. Minha intenção no entanto sempre foi de dizer tudo. Mas há um grau na confidência que não se pode ultrapassar sem artifício; e eu busco sobretudo o natural. (...) Tudo é sempre mais complicado do que dizemos. Talvez mesmo nos aproximemos mais da verdade no romance." Si le grain ne meurt. p. 280.

${ }^{127}$ Journal, Ano 1909, apud Barthes, R. "Notas sobre André Gide e seu diário”, p. 7.
} 
um mito, mas insinuam também a grande presença humana naquilo que escrevo. Dizem que não estou lá através de acusações de inconstância, de inconsistência, de falta de personalidade, mas vocês podem me encontrar, subjacente, humano, bem aqui. Minha presença, eu sei, é absurda, é impossível, diante das circunstâncias, da repetição, perseverar nessa reafirmação obstinada. Mas eu quero acima de tudo estar aqui. 


\section{Lista de figuras}

I. Figura da p. 18: Fotografia do mergulhador Henri Kaiser na Antártica, retomada por Werner Herzog em Encounters at the end of the world. Disponível em: http://www.shackletoncentenary.org/Werner\%20Herzog\%20Antarctica.jpg Consultada em: 10/01/2015.

II. Figura da p. 62: La Porte étroite, páginas 44-5.

III. $\quad$ Figura da p. 93: Le Prométhée Mal Enchaîné, páginas 78-9.

IV. Figura da p. 102: Nuvem conceitual criada a partir do texto desta dissertação.

V. Figura da p. 104: Projeção de Mercator.

VI. Figura da p. 106: Página inicial do site da pesquisadora Karen O’Rourke.

VII. Figura da p. 107: MACHADO, João. Swimming, 2007. In: HARMON, K. You are here: personal geographies and other maps of imagination. p. 35

VIII. Figura da p. 113: Printscreen do filme Persona, de Ingmar Bergman, 1966. 


\section{Planície de associações}

\section{Livros:}

GIDE, André. Ainsi soit-il ou les jeux sont faits. Paris: Gallimard, 2001.

Corydon. Paris: Gallimard, 2006.

Diário dos moedeiros falsos. São Paulo: Estação Liberdade, 2009.

Essais critiques. Paris: Bibliothèque de la Pléiade, Gallimard, 1999.

Journal. T. I. 1887-1925. Paris : Bibliothèque de la Pléiade, Gallimard, 1996.

Journal. T. II. 1926-1950. Paris : Bibliothèque de la Pléiade, Gallimard, 1997.

L'Immoraliste. Paris : Folio, 2010.

La Porte étroite. Paris : Folio, 1959.

La Symphonie pastorale. Paris : Folio, 2012.

Les Caves du Vatican. Paris : Folio, 1997.

Les Faux-monnayeurs. Paris : Folio, 2011.

Les Nourritures terrestres suivi des Nouvelles nourritures. Paris: Folio, 2009.

Le Prométhée Mal Enchaîné. Paris: Gallimard, 1992.

Morceaux choisis. Paris: Gallimard, 1935.

O pombo-torcaz. São Paulo: Estação Liberdade, 2009.

Os moedeiros falsos. São Paulo: Estação Liberdade, 2009.

Paludes. Paris : Folio, 2008. 
Si le grain ne meurt. Paris: Folio, 2009.

ADORNO, Theodor. Notas de literatura I. São Paulo: Editora 44/Duas Cidades, 2002.

AGAMBEN, Giorgio. Ideia da prosa. Belo Horizonte: Autêntica Editora, 2012.

ANGLÈS, Auguste. André Gide et le premier groupe de La Nouvelle Revue Française. La formation du groupe et les années d'apprentissage 1890-1910. Paris : Gallimard, 1978.

ARAUJO, Renata Lopes. André gide e Georges Perec: os diálogos potenciais. Dissertação (Mestrado) - USP, São Paulo, 2009.

BARTHES, Roland. “Deliberação". In: O rumor da língua. São Paulo: Editora Brasiliense, 1988. “Notes sur André Gide et son journal”, In : CEuvres Complètes I. Paris: Éditions du Seuil, 2002.

Le Degré zéro de l'écriture suivi de Nouveaux essais critiques. Paris: Éditions du Seuil, 1953 e 1972.

“Notas sobre André Gide e seu diário", In: Inéditos, Vol 2. Crítica. São Paulo: Martins Fontes, 2004.

Fragments d'un discours amoureux. ; "Délibération ", In : CEuvres Complètes V.

Paris : Éditions du Seuil, 2002.

Roland Barthes par Roland Barthes. Paris: Éditions du Seuil, 1975.

BASTIDE, Roger. Anatomie d'André Gide. Paris: L'Harmattan, 2006.

BAUDRILLARD, Jean. As estratégias fatais. Lisboa: Editorial Estampa, 1991.

BENVENISTE, Émile. Problèmes de Linguistique Générale I. Paris : Gallimard, 2012. Problèmes de Linguistique Générale II. Paris: Gallimard, 2011. 
BORGES, Jorge Luis. Fiç̧ões. São Paulo: Companhia das Letras, 2007.

CAMPOS, Regina Salgado "André Gide e o século XX: questionamento do romance". In: Revista Lettres françaises, №. 7. Araraquara, 2006. pp. 27-38.

CANDIDO, Antonio. "Machado de Assis de outro modo" In: Recortes. São Paulo: Companhia das Letras, 1996.

DERRIDA, Jacques. "História da mentira: prolegômenos". In: Revista Estudos Avançados. №10 (27), 1996. pp. 7-39.

DOSTOIEVSKI, Fiódor. O idiota. São Paulo: Editora 34, 2010.

FOUCAULT, Michel. “Des espaces autres” (1967). In: Dits et écrits 1984, T IV. Paris: Gallimard, 1984.

Les mots et les choses. Paris : Gallimard, 2010.

As palavras e as coisas. São Paulo: Martins Fontes, 2000.

GAGNEBIN, Jeanne-Marie. "O método desviante". In: Revista Trópico. 3/12/2006. Disponível em: http://www.revistatropico.com.br/tropico/html/textos/2807,1.shl Acesso em: 01/08/2014

GENETTE, Gérard. Métalepse. De la figure à la fiction. Paris : Éditions du Seuil, 2004.

GODARD, Henri. Le roman modes d'emploi. Paris: Gallimard, 2006.

GOMES, Lívia C. Machado com Flaubert ou a política da escrita. Dissertação (Mestrado) Faculdade de Filosofia, Letras e Ciências Humanas da Universidade de São Paulo. São Paulo, 2011.

GOULET, Alain. Lire Les faux-monnayeurs. Paris: Dunod, 1994. 
André Gide, Les faux-monnayeurs : Mode d'emploi. Paris: SEDES, 1991.

“Gide em pauta”, In: Revista ALEA, Vol. 5. №. 2, Jul.-Dez. de 2003. pp. 195-211. “L'auteur mis en abyme (VALÉRY et GIDE)", In: Revista Lettres françaises, №. 7.

Araraquara, 2006. pp. 39-58.

HARMON, Katharine. The map as art. Contemporary artists explore cartography. Princeton: Princeton Architectural Press, 2009.

You are here: personal geographies and other maps of the imagination.

Princeton: Princeton Architectural Press, 2003.

LACAN, Jacques. "La jeunesse de Gide ou la lettre et le désir". In : Écrits. Paris : Le Seuil, 1966.

LEJEUNE, Philippe. Le pacte autobiographique. Paris : Éditions du Seuil, 1975.

LÉVINAS, Emmanuel. “Enigma y fenómeno”. Disponível em:

http://www.cybertesis.cl/tesis/uchile/2004/valdivia_m/html/index-frames.html Acesso em: $13 / 01 / 2011$

LOSOWSKY, Andrew. EHMANN, Sven. et al. Around the World. The atlas for today. Berlim: Gestalten, 2013.

MANNING, Scott. "Revelation and Dissimulation in André Gide's Autobiographical Space”, In:

The French Review, Vol. 78. №. 2, Dez., 2004. pp. 318-327.

MARTIN, Claude. Gide. Paris : Les Éditions du Seuil, 1986.

MARTY, Éric. L'écriture du jour. Le Journal d'André Gide. Paris : Éditions du Seuil, 1985. 
PAIT, Heloisa. "As alunas e os contos: a narrativa curta brasileira num curso de escrita criativa nos Estados Unidos". In: Revista Brasileira de Literatura Comparada. №. 15, 2009. pp. 173189.

PEREIRA, Viviane Araújo Alves da Costa. Ionesco crítico em: "Da teoria da derrisão à derrisão da teoria". Tese (Doutorado). USP - São Paulo, 2014.

PINO, Claudia Consuelo Amigo. Em busca de uma vida nova: o projeto de romance de Roland Barthes. Tese (Livre docência). USP - São Paulo, 2013.

POULET, Georges. La pensée indéterminée. Vol. II. Paris : Puf, 1985.

QUIGNARD, Pascal. Boutès. Paris : Éditions Galilée, 2008.

Une gêne technique à l'égard des fragments. Paris : Galilée, 2005.

RANCIÈRE, Jacques. O mestre ignorante. Cinco lições sobre a emancipação intelectual. Belo Horizonte: Autêntica, 2002.

A partilha do sensível. Estética e política. São Paulo: Editora 34, 2009.

Politique de la littérature. Paris: Galilée, 2007.

Políticas da escrita. São Paulo: Editora 34, 2005.

"Rancière fala à Folha sobre democracia". Entrevista com Úrsula Passos para o jornal Folha de São Paulo, 26/10/2014. Disponível em: http://www1.folha.uol.com.br/ilustrissima/2014/10/1537265-jacques-ranciere-fala-a-folhasobre-democracia.shtml Acesso em: 26/10/2014.

RIBEIRO, Sheila Canevacci. Ribeiro, S. C. Congruência absurda // corpomídia da metrópole comunicacional. Tese (Doutorado) - PUC/SP. São Paulo, 2014. 
SARTRE, Jean-Paul. "Gide vivant", In: Les temps modernes, 66 | março/1951. Disponível em: http://e-gide.blogspot.com.br/2013/04/gide-vivant-par-j-p-sartre.html. Acesso em: $01 / 08 / 2014$

STAROBINSKI, Jean. La Relation critique. Paris : Gallimard, 2001.

TOLSTÓI, Liev. Guerra e paz. São Paulo: Cosac Naify, 2011.

VIOLLET, Catherine. "Martine Sagaert - Les manuscrits du Journal d’André Gide », Genesis [Online], 32 | 2011. Disponibilizada em 17/05/2013, consultada em 02/07/2013. URL: http://genesis.revues.org/514

WINTER, Ligia Maria. Escritas do suporte. Tese (Doutorado). UNICAMP - Campinas, 2012.

WOOD, Denis. I don't want to, but I will. Disponível em:

http://www.deniswood.net/lp_idwtbiw.htm Consultado em: 24/01/2015.

\section{Filmes:}

Encounters at the end of the world. Direção: HERZOG, Werner. Discovery Films, 2007. 99 min.

Gasherbrum, a montanha luminosa. Direção: HERZOG, Werner. Süddeutscher Rundfunk/Werner Herzog Filmproduktion, 1985. 45 min.

Persona. Direção: BERGMAN, Ingmar. Svensk Filmindustri, 1966. 85 min.

The Weight of Mountains. Direção: DORAN, Temujin. 2014. 11'35 min. Disponível em: http://vimeo.com/87651855 Acesso em: 10/03/2014. 


\section{Exposição:}

"Yo Picasso. Autorretratos". Museo Picasso, Barcelona, 2013.

\section{Sites:}

Instituto Brasileiro de Geografia e Estatística (IBGE) http://atlasescolar.ibge.gov.br/mapasatlas/mapas-do-mundo/divisoes-politicas-e-regionais Acesso em: 14/11/2014.

O'Rourke, Karen. A Map larger than the territory. Disponível em: http://www.mapterritory.com/?lang=en. Acesso em: 14/11/2014.

The Institute for Infinitely Small Things. Disponível em:

http://www.ikatun.org/institute/infinitelysmallthings/ Acesso em: 02/08/2014 http://judgmentalmaps.com/ Acesso em: 15/12/2014.

Série televisiva:

American Horror Story: Murder House. (Série televisiva). Brad Falchuk Teley-vision \& Ryan Murphy Productions. Temporada exibida por Fox Broadcasting Company, 2010. 